\title{
Facilitating student engagement through the flipped learning approach in K-12: A systematic review
}

\begin{abstract}
The flipped learning approach has been growing in popularity in both higher education and K12 , especially for its potential to increase active learning and student engagement. However, further research is needed to understand exactly how the flipped approach enhances student engagement. This narrative systematic review synthesises literature published between 20122018, focused on the flipped learning approach in K-12 contexts, and indexed in 7 international databases. 107 articles, book chapters, dissertations, conference papers and grey literature were included for review, and the results are discussed against a bioecological model of student engagement. Studies in this review found the approach to overwhelmingly support student engagement, with $93 \%$ of studies citing at least one dimension of behavioural, affective or cognitive engagement, whereas $50 \%$ of studies reported facets of disengagement. Collaborative technologies such as Google Docs, Google Classroom and Edmodo were particularly linked to engagement, with videos not created by teachers more likely to lead to disengagement. The results indicate that the majority of research has been undertaken in North American and Asian high schools, heavily focused on student perceptions of flipped learning and achievement within STEM subjects, especially Mathematics, with a slight preference for quantitative methods. Only $12 \%$ included a definition of student engagement, and less than half used a theoretical framework. Future empirical research should ensure that all contextual information is included, including year level of student participants, that multiple methods of both quantitative and qualitative data collection are included, and close attention is paid to grounding research in theory. Further research is needed on parent, teacher and school leader perceptions, as well as longitudinal and multiple-class studies.
\end{abstract}

\section{Keywords}

Flipped learning, K-12, teaching/learning strategies, pedagogical issues, improving classroom teaching

\section{Introduction}

Developing and maintaining student engagement, and increasing opportunities for students to develop $21^{\text {st }}$ century and educational technology skills, are vital considerations for K-12 educators (Claro \& Ananiadou, 2009). The degree to which this is achieved can have a profound effect on students' cognitive development and learning outcomes (Ma, Han, Yang, \& Cheng, 2015), with disengagement in learning a predictor of dropout (Finn \& Zimmer, 2012). Flipped learning is an approach that has "great promise" (OECD, 2018, p. 77) to bring technology more into the classroom, help develop students' digital competencies (Kostaris, Sergis, Sampson, Giannakos, \& Pelliccione, 2017), increase higher order thinking skills and active learning time (Gough, DeJong, Grundmayer, \& Baron, 2017), promote problem solving, teamwork and collaboration skills (Lo \& Hew, 2017), and has the potential to enhance both parent and student engagement (Bond, 2019; Aycicek \& Yelken, 2018).

With theoretical foundations in collaborative learning theory and constructivism (Bishop \& Verleger, 2013), flipped learning is a student-centered approach that inverts traditional lessons, by providing content to students outside of the classroom that would usually be taught by the teacher at school (Song \& Kapur, 2017), such as lectures or teacher explanations. By students learning and reviewing concepts at home, class time can then be freed up for active, collaborative activities within the group space, and increased time with the teacher (Lo \& Hew, 
2017). Whilst disagreement continues on its exact definition and design (see van Alten, Phielix, Janssen, \& Kester, 2019), and in particular whether it includes an out-of-class video component (e.g., Cheng, Ritzhaupt, \& Antonenko, 2018) or not (e.g., Bergmann \& Sams, 2012; Gough et al., 2017), many researchers agree that flipped learning includes "interactive group learning activities inside the classroom, and direct computer-based individual instruction outside the classroom" (Bishop \& Verleger, 2013, p. 4).

Whilst the approach has been gaining popularity, particularly since 2013 (Karabulut-Ilgu, Jaramillo Cherrez, \& Jahren, 2018), following the release of early pioneers Bergmann and Sams' book in 2012 (Bergmann \& Sams, 2012), and there is a growing body of literature and systematic reviews endeavouring to synthesise this body of evidence (see Appendix A), there remains a paucity of research undertaken within K-12 contexts (Lundin, Bergviken Rensfeldt, Hillman, Lantz-Andersson, \& Peterson, 2018), with only 16\% of 71 flipped learning studies published between 2000-2016, and indexed within the Web of Science, focused on K-12 learners (Akçayır \& Akçayır, 2018). Seven reviews or meta-analyses were identified that include K-12 studies across any subject area (Akçayır \& Akçayır, 2018; Cheng, Ritzhaupt, \& Antonenko, 2018; Lo \& Hew, 2017; Lo, Hew, \& Chen, 2017; Lundin et al., 2018; Tütüncü \& Aksu, 2018; van Alten et al., 2019), however all seven included small sample sizes, with 11, 12, 15, nine, four, eight and 11 studies respectively, and the review by Tütüncü and Aksu (2018) was focused on Turkish research only. Furthermore, whilst these reviews did focus on the advantages and challenges of flipped learning in schools, their treatment of its effect on student engagement was limited. For example, whilst 'engagement' was considered as a positive learning outcome within the study by Akçayır and Akçayır (2018), the term itself was not defined, as understood by the review authors or by the article authors included in the review. Whilst student engagement is a complex and multifaceted construct (Appleton, Christenson, \& Furlong, 2008; Reschly \& Christenson, 2012), which has resulted in inconsistent definitions across the field (Henrie, Halverson, \& Graham, 2015), greater understanding of the role that educational technology plays in student engagement, and stronger evidence of the outcomes that flipped learning promotes, is vital to ensure improved outcomes for students (O'Flaherty, Phillips, Karanicolas, Snelling, \& Winning, 2015). Therefore, this systematic review is an important addition to the literature by identifying and synthesising research, investigating how flipped learning affects student engagement in $\mathrm{K}-12$, across all three dimensions of student engagement (Fredricks, Blumenfeld, \& Paris, 2004; Fredricks, Filsecker, \& Lawson, 2016).

\section{Literature Review}

\subsection{Student engagement}

Enhancing and maintaining student engagement is an important goal of educators, given its link to improved persistence, achievement and retention (Finn, 2006; Kuh, Cruce, Shoup, Kinzie, \& Gonyea, 2008). Whilst there are ongoing conversations about the nature and composition of student engagement (e.g. Eccles, 2016), and space in the present article does not allow a lengthy consideration of the concept (see Bond \& Bedenlier, 2019; Bond, Buntins, Bedenlier, Zawacki-Richter, \& Kerres, 2020), it is important that a clear definition is provided in each study (Boekarts, 2016). Therefore, student engagement is defined as:

the energy and effort that students employ within their learning community, observable via any number of behavioural, cognitive or affective indicators across a continuum. It is shaped by a range of structural and internal influences, including the complex interplay of relationships, learning activities and the learning environment. The more students are engaged and empowered within their learning community, the more likely they are to channel that energy back into their learning, leading to a range of short and 
long term outcomes, that can likewise further fuel engagement. (Bond et al., 2020, p. 3)

There are three widely accepted dimensions of engagement; cognitive, affective and behavioural (Fredricks et al., 2004; Fredricks, Filsecker, \& Lawson, 2016). Cognitive engagement relates to understanding, self-regulation and deep learning strategies, affective engagement relates to students' interest and sense of belonging, as well as positive reactions to teachers, peers and the learning environment, and behavioural engagement relates to persistence, participation and positive conduct. Each engagement dimension includes several indicators of student engagement and disengagement (see Appendix B), which fluctuate on a continuum (Coates, 2007; Payne, 2017), depending on their activation (high or low) and valence (positive or negative) (Pekrun \& Linnenbrink-Garcia, 2012).

\subsubsection{Conceptual framework}

Student engagement, however, is influenced and impacted by a range of contextual factors, and it is crucial that these are considered when explorations of student engagement are undertaken (Appleton et al., 2008; Kahu, 2013; Quin, 2017). Drawing on a review of student engagement literature, undertaken as part of the author's PhD by publication (see Bond \& Bedenlier, 2019; Bond et al., 2020), a bioecological student engagement framework was developed (see Figure 1). This model was adapted from the bioecological model by Bronfenbrenner and colleagues (e.g. Bronfenbrenner, 1979, 1986; Bronfenbrenner and Ceci, 1994), and Schwab's (1973) framework of curriculum redevelopment, and an initial version of it arose out of the results of a flipped learning case study by the author (Bond, 2019). The student is placed at the centre of the microsystem, which includes their immediate setting, e.g. home or classroom, and which is then nested within intertwined milieus; the mesosystem, which represents interactions between microsystems and between the micro and exosystems; the exosystem, which includes wider social structures impacting on the learner; and the macrosystem, which encompasses wider social, economic, political, educational and legal systems, in which all systems are located.

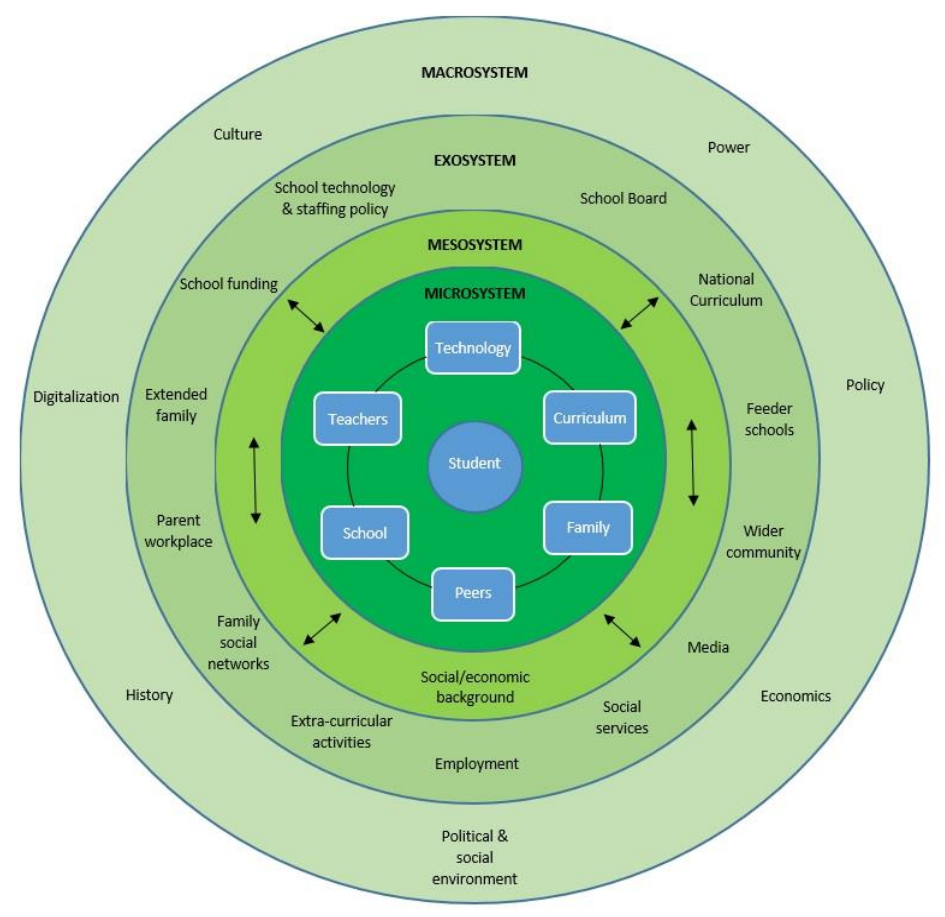

Figure 1. Bioecological model of influences on school student engagement, adapted from Bond (2019, p. 1305) and Bond \& Bedenlier (2019, p. 5) 
These milieus influence - and are likewise influenced by - student engagement, leading to a range of short and long term academic and social outcomes, which can also further promote engagement, and impact the various systemic levels. The interplay of a classroom microsystem implementing the flipped learning approach and student engagement could be visualised as:

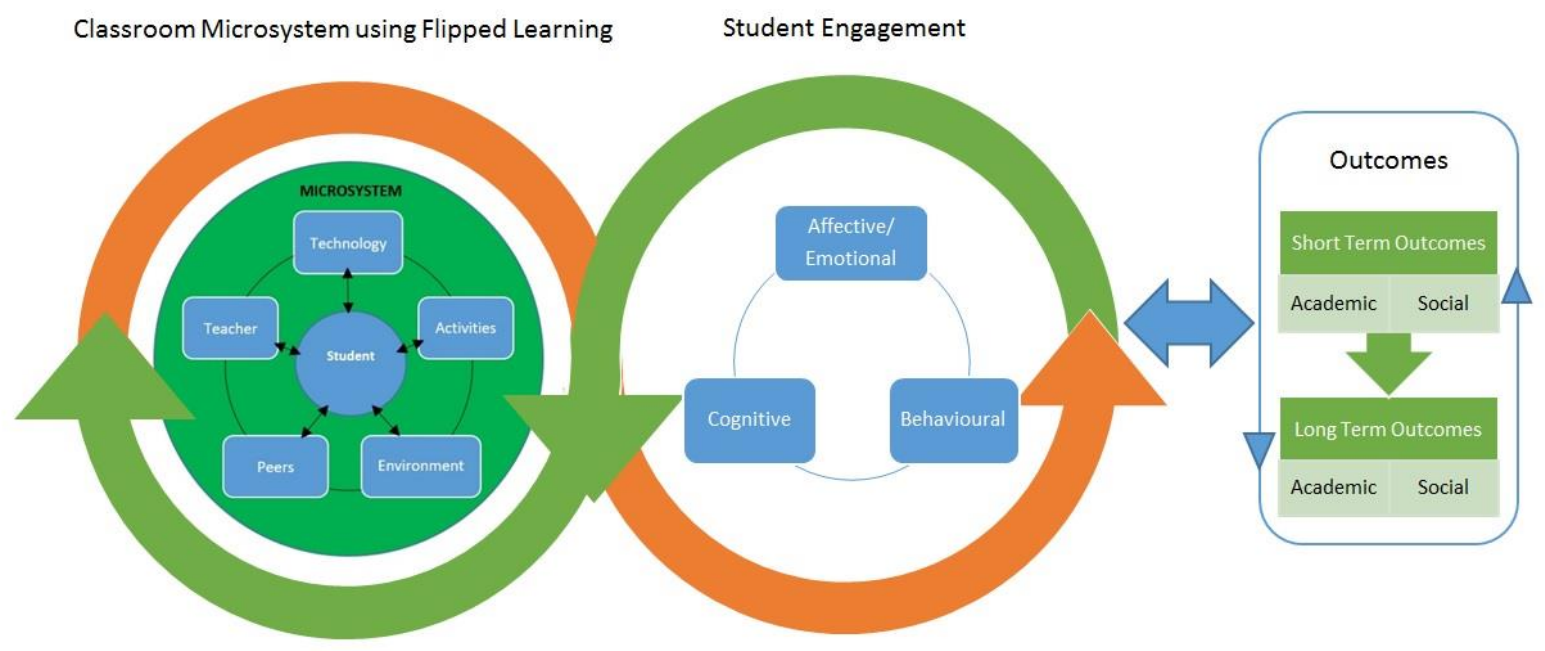

Figure 2. Flipped learning student engagement conceptual framework

The microsystem presented here reflects the classroom where flipped learning is being used, with the student located at the centre, interacting with the teacher, peers, technology, learning activities and the learning environment. The interplay of these can affect any number of student engagement indicators to varying degrees, leading to a range of short and long term outcomes, which can then in turn affect engagement, and subsequently impact on the microsystem (Bond \& Bedenlier, 2019). However, further investigation of the ways in which flipped learning affects student engagement could help educators to make more informed decisions when implementing the approach, alongside deepening our understanding of student engagement itself.

\subsubsection{Student engagement, educational technology and flipped learning}

There is a growing body of research on the potential of educational technology to enhance student engagement (e.g. Schindler, Burkholder, Morad, \& Marsh, 2017), although the majority of this has been focused on higher education (Henrie et al., 2015) and in the area of STEM (e.g. Nikou \& Economides, 2018). Reviews that have found a small positive impact on student engagement include those centred on social media (Cheston, Flickinger, \& Chisolm, 2013), mobile learning (Kaliisa \& Picard, 2017), and audience response systems (Hunsu, Adesope, \& Bayly, 2016; Kay \& LeSage, 2009). Reviews focusing solely on flipped learning and student engagement, however, have revealed mixed results (e.g. Chen, Lui, \& Martinelli, 2017; Njie-Carr et al., 2017). The scoping review by O'Flaherty et al. (2015), for example, found very limited evidence to support increased engagement, aside from a modest improvement in increased exam scores or student satisfaction, and they therefore called for future research to examine other indicators of engagement. A number of previous reviews have also stressed the need for more rigorous research design (e.g. Lo \& Hew, 2017; Ward, Knowlton, \& Laney, 2018), including adequate sample sizes and complete information of study context and participants.

\subsection{Previous reviews on flipped learning in K-12}

Five literature and systematic reviews on flipped learning, as well as two meta-analyses, including K-12 research in any subject area, have been published in the last three years (see 
Appendix C), in an attempt to gain an overview of the field, to identify benefits and challenges to using the approach, as well as to suggest recommendations for future empirical research. The study by Tütüncü and Aksu (2018) was focused on research in Turkey, whereas the other six studies included research from anywhere. Lo and Hew (2017); Lo et al. (2017) and Lundin et al. (2018) all found a large amount of research on flipped learning originated from the US, which represented 61\% $(n=323)$ of research published between 2010-2016 in Scopus (Lundin et al., 2018). Of the 15 studies included in Lo and Hew's (2017) review, however, six studies had been undertaken in Taiwan; an increasing trend also seen in the wider educational technology research field (e.g. Bond, Zawacki-Richter, \& Nichols, 2019; Zawacki-Richter \& Latchem, 2018).

Limited information was given as to the educational settings of the articles included in the reviews, however Cheng et al. (2018) point out that this could be due to the lack of information about research design given in empirical research. Lo and Hew (2017) reported that only two studies were set in elementary/primary schools (one Year 4 and one Year 6) and 13 were undertaken in high schools (see Appendix C). So too Lo et al.'s (2017) review on flipped learning in Mathematics found that only $9.7 \%$ were undertaken in secondary schools and $2.8 \%$ in primary, and four studies in Tütüncü and Aksu's (2018) review were set in elementary schools and four in high schools. Lo and Hew (2017) and Lundin et al. (2018) both found that quantitative methods were the most used, and both recommend that more qualitative research should be undertaken, alongside increased design-based and longitudinal research (Akçayır \& Akçayır, 2018). Van Alten et al. (2019) suggest that more K-12 studies with robust designs, that include control groups, are needed, and Lo et al. (2017) stressed the need for more clearly define the flipped intervention design. Both Lo and Hew (2017) and Lundin et al. (2018) recommend that further research should be undertaken outside of STEM subject areas, however Cheng et al. (2018) warn that in subjects that require frequent hands-on learning, a flipped learning approach may overwhelm students. Akçayır and Akçayır (2018) recommend that more studies investigating flipped learning across subjects be undertaken. Therefore, the present review seeks to investigate whether a wider search strategy can locate such literature. It also seeks to provide a broader understanding of the state of K-12 flipped learning research, to gain a clearer idea of what research has already been undertaken, in order to shine a light on potential research gaps. This will help researchers pinpoint which year levels and subject areas need further investigation, and in which journals such research might be published.

\subsubsection{Benefits of flipped learning}

Flipped learning has been shown to significantly increase learning performance and achievement (Akçayır \& Akçayır, 2018; Lo et al., 2017; Tütüncü \& Aksu, 2018) and active learning within the classroom (Lo \& Hew, 2017; Tütüncü \& Aksu, 2018), although questions of rigorous research design cast some light on these findings (Lo et al., 2017; Lundin et al., 2018). Students find re-watching videos and revisiting content particularly helpful (Lo \& Hew, 2017; Lundin et al., 2018; Tütüncü \& Aksu, 2018), so too the increased individual assistance that can be provided by the teacher in the group space as a result (Lo \& Hew, 2017; Lundin et al., 2018), as well as learning with and from peers (Lo et al., 2017).

\subsubsection{Challenges with flipped learning}

Flipped learning does not always receive positive reactions, however, with some students feeling less satisfied when using flipped, as opposed to traditional methods (Lo \& Hew, 2017; Lundin et al., 2018), which may be due in part to unfamiliarity with the approach (Lo et al., 2017; Tütüncü \& Aksu, 2018). There are also a number of other challenges that need to be considered, including teacher IT skills (Lo \& Hew, 2017), the amount of time it takes for 
teachers to prepare flipped content (Akçayır \& Akçayır, 2018; Lo \& Hew, 2017; Lo et al., 2017), producing the appropriate length and quality of videos (Akçayır \& Akçayır, 2018; Lo \& Hew, 2017; Tütüncü \& Aksu, 2018), and access to adequate, functional technology both at home and at school (Akçayır \& Akçayır, 2018; Lo \& Hew, 2017; Tütüncü \& Aksu, 2018).

\subsubsection{Impact on student engagement}

Whilst these reviews were not focused on student engagement specifically, they did mention improvements in various indicators of engagement, including increased satisfaction (Akçayır \& Akçayır, 2018; Lo \& Hew, 2017; van Alten et al., 2019), enjoyment (Tütüncü \& Aksu, 2018), positive and increased interactions with the teacher and peers (Akçayır \& Akçayır, 2018; Lo \& Hew, 2017; Lo et al., 2017; Lundin et al., 2018; Tütüncü \& Aksu, 2018), and overall engagement (Akçayır \& Akçayır, 2018). It should be noted, however, that flipped learning resulted in higher student satisfaction in van Alten et al.'s (2019) study, only when lecture activities were included (such as microlectures or just-in-time lessons responding to quiz results). Whilst motivation is considered an antecedent to engagement (Bond et al., 2020), $61 \%$ of studies in the review by Lundin et al. (2018) found improved motivation or student learning.

\subsubsection{Research Questions}

Against this background, this study adopts a systematic research methodology, in order to synthesise previous literature on the flipped learning approach in $\mathrm{K}-12$, to further understanding of how it affects student engagement, and guide practitioners and researchers in future practice and research. The present study seeks to answer the following questions:

1. What are the characteristics (countries, educational settings, participants, subjects, length of studies) of and methods used in research on flipped learning and student engagement in K-12?

2. How is research on flipped learning in $\mathrm{K}-12$ theoretically grounded?

3. Which indicators of student engagement and disengagement are affected as a result of using the flipped learning approach in K-12?

4. What technology has been used in K-12 applications of flipped learning research, and how is it linked to engagement?

\section{Method}

With the intent to uncover how flipped learning affects student engagement in $\mathrm{K}-12$, a systematic review was conducted, using an explicit and replicable search strategy, with studies then excluded or included, based on pre-determined criteria (Gough, Oliver, \& Thomas, 2012), and following the PRISMA reporting guidelines (Brunton, Stansfield, \& Thomas, 2012; Moher, Liberati, Tetzlaff, \& Altman, 2009). The PRISMA guidelines were developed to help improve the reporting of systematic reviews and meta-analyses, primarily in the context of healthcare, and consists of a checklist of 27 items across the title, abstract, methods, results, discussion and funding (see Liberati et al., 2009 for detailed information about how to report on each item), as well as a four phase flow diagram. The PRISMA flow diagram should appear in each systematic review and clearly outline the study identification, screening, eligibility and inclusion processes, including reasons for study exclusion (see www.prisma-statement.org for more information). Three separate searches were conducted on 14 December 2017, 31 July 2018 and 31 January 2019, to ensure that all relevant articles were included in the sample. Therefore, the flow diagram for this review (see Figure 5) has been adapted to reflect the exact process undertaken (from Brunton et al., 2012, p. 86; Moher et al., 2009, p. 8). 


\subsection{Search Strategy and Selection Procedure}

Whilst three reviews (Akçayır \& Akçayır, 2018; Lo \& Hew, 2017; Lundin et al., 2018) purposefully avoided time limits in their search, in order to chart the development of flipped learning across time, both Akçayır and Akçayır (2018) and Lo and Hew (2017) found that most of the studies in their sample were published in 2015 and 2016, with Lundin et al. (2018) also noting a substantial increase in 2015. Given that the book by flipping 'pioneers' Bergmann and Sams was published in 2012, the decision was made to limit the search period to empirical research, published in English between 2012 and 2018. Whilst two studies searched for literature within eight databases (Lo \& Hew, 2017; Tütüncü \& Aksu, 2018), including ERIC, one study limited their search to SSCI indexed journals in the Web of Science database (Akçayır \& Akçayır, 2018), and one chose Scopus (Lundin et al., 2018), as "it covers a wider array of peer-reviewed references and is more multidisciplinary in character" (p. 5). Therefore, the decision was made to include ERIC, Web of Science, Scopus, ProQuest, PsycINFO, Teacher Reference Center and Education Source, which were also all found to be well-suited to evidence synthesis, meeting all necessary performance requirements in a recent review (Gusenbauer \& Haddaway, 2019).

\subsubsection{Search string}

The search string (see Figure 3) focused on formal educational settings, K-12 and flipped learning, using * for truncations. Given the complex nature of student engagement, it was decided not to search explicitly for the term engagement, as important studies might have been missed that focus on indicators of engagement, but which do not use the term (Bond et al., 2020). Due to the large amount of flipped learning studies in the health sciences (e.g., Chen et al., 2017), terms such as "medical school" and "dental education" needed to be added to the search string as NOT items, in order to further refine the results.

\begin{tabular}{l}
\hline \multicolumn{1}{c}{ Search terms } \\
\hline class* OR learn* \\
AND \\
"K-12" OR kindergarten OR kindy OR "primary school" OR "middle school" OR "secondary \\
school" OR school OR "high school" OR "reception" OR "R-12" OR "junior primary" OR \\
"elementary school" OR "middle primary" OR "upper primary" OR "senior school" \\
AND \\
"flip* classroom" OR "flip* learning" OR "inverted instruction" OR "flipping" OR "flipped" OR \\
invert* \\
NOT \\
"higher education" OR universit* OR college OR undergrad* OR graduate OR postgrad* OR \\
"corporate training" OR "professional training" OR "vocational education" OR "adult education" \\
OR "medical school" OR "medical student" OR "dental education" \\
\hline
\end{tabular}

Figure 3. Search string

\subsubsection{Inclusion/Exclusion criteria}

The initial search yielded 949 records, which were imported into systematic review software EPPI Reviewer ${ }^{1} .189$ duplicates were then automatically removed, leaving 760 abstracts and titles that were then screened, applying the inclusion/exclusion criteria (see Figure 4). Studies were included if they reported on empirical research published between 2012-2018, written in English, focused on any grade between kindergarten and Year 12, and explored flipped

\footnotetext{
${ }^{1}$ http://eppi.ioe.ac.uk/cms/Default.aspx?alias=eppi.ioe.ac.uk/cms/er4
} 
learning. Given the disparity that continues on the definition of flipped learning (see van Alten et al., 2019), it was decided to include studies that used any form, including those that did and did not use videos. The tools/technology used were then coded during data extraction.

\begin{tabular}{ll}
\hline \multicolumn{1}{c}{ Inclusion Criteria } & \multicolumn{1}{c}{ Exclusion Criteria } \\
\hline Published between 2012-2018 & Published before 2012 \\
English language & Not in English \\
K-12/schools focused & Not K-12 \\
Flipped learning & Not flipped learning \\
Empirical, primary research & No student engagement \\
Indexed in ERIC, Web of Science, Scopus, & No learning setting \\
ProQuest, PsycINFO, Teacher Reference Center, & Description of a tool \\
Education Source & Not primary research \\
\hline
\end{tabular}

Figure 4. Inclusion and exclusion criteria

Studies were excluded if they focused on other study levels (e.g. undergraduates), if they did not use some form of flipped or inverted learning, if they only described or evaluated a tool, if they were not undertaken within a learning setting (i.e. a formal class in a school), or if they were not primary research (e.g. a systematic review). Studies were also excluded if they did not explore or report on an aspect of student engagement, as per the indicators identified (see Appendix B). Following the next two search iterations, 107 journal articles, book chapters, dissertations, conference papers and other grey literature were included for synthesis (see Figure 5 and Appendix $\mathrm{G}$ for a list). Studies that were excluded on quality included those that did not give enough information about sample size or study design, or that contained inconsistent information.

\subsection{Data Extraction}

In order to extract article data, the coding system developed and used by Bond et al. (2020) was slightly modified ${ }^{2}$, in which inter-coder reliability was high. Codes included article details (e.g. publication and country of authors), description of the study sample (e.g. country, number of participants, educational setting), study design (e.g. length, theoretical model), methodology (approach, data collection and analysis), and the findings. In order to provide a more complete overview of intervention studies included in the sample (see Hoffmann et al., 2015), information pertaining to how 'traditional' learning environments are described in the studies was also coded. Specific examples of engagement and/or disengagement were coded under cognitive, affective or behavioural (dis)engagement, which were identified based on a previous literature review (see Appendix B). In this way, the diverse complexity of each dimension could be explored. The benefits and challenges of flipped learning were also coded as they emerged in the articles. Whilst some people may consider achievement a form of engagement, it is seen in this study as an outcome of being engaged, and therefore was coded separately. In order to explore how technology was used and its link to engagement, any educational technology tool was coded as they appeared, including specific Learning Management Systems (LMS).

\subsection{Data Synthesis}

Due to the heterogeneity of the studies included in this review, owing in part to the complex nature of student engagement, it was decided not to undertake a meta-analysis. Whilst it is possible to conduct a statistical analysis of the achievement data, this is not the focus of the

\footnotetext{
${ }^{2}$ See https://www.researchgate.net/project/Facilitating-student-engagement-through-the-flipped-classroomapproach-in-K-12 for an open access copy of the full code set.
} 
research question guiding the present review. Therefore, a narrative synthesis of the quantitative and qualitative data was undertaken, which is a valid method of analysing and assembling evidence (see Petticrew \& Roberts, 2006, Chapter 6). This method involves tabulating the included studies (see Appendix G), to provide an overview of the study setting, methods, participants, intervention, and study findings. However, as one table is not enough to clearly summarise the results of such a large corpus, further tables are used throughout the text (e.g. Table 4) to provide an overall summary of engagement and disengagement indicators, as well as the benefits and challenges identified. This is then accompanied by a narrative description, summarising the results under each (dis)engagement dimension. The results are then discussed against the bioecological model developed by the author (see Figure 7), in an attempt to identify recommendations for teachers and schools to successfully implement the flipped learning approach, as well as to further expand our understanding of influences on student engagement.

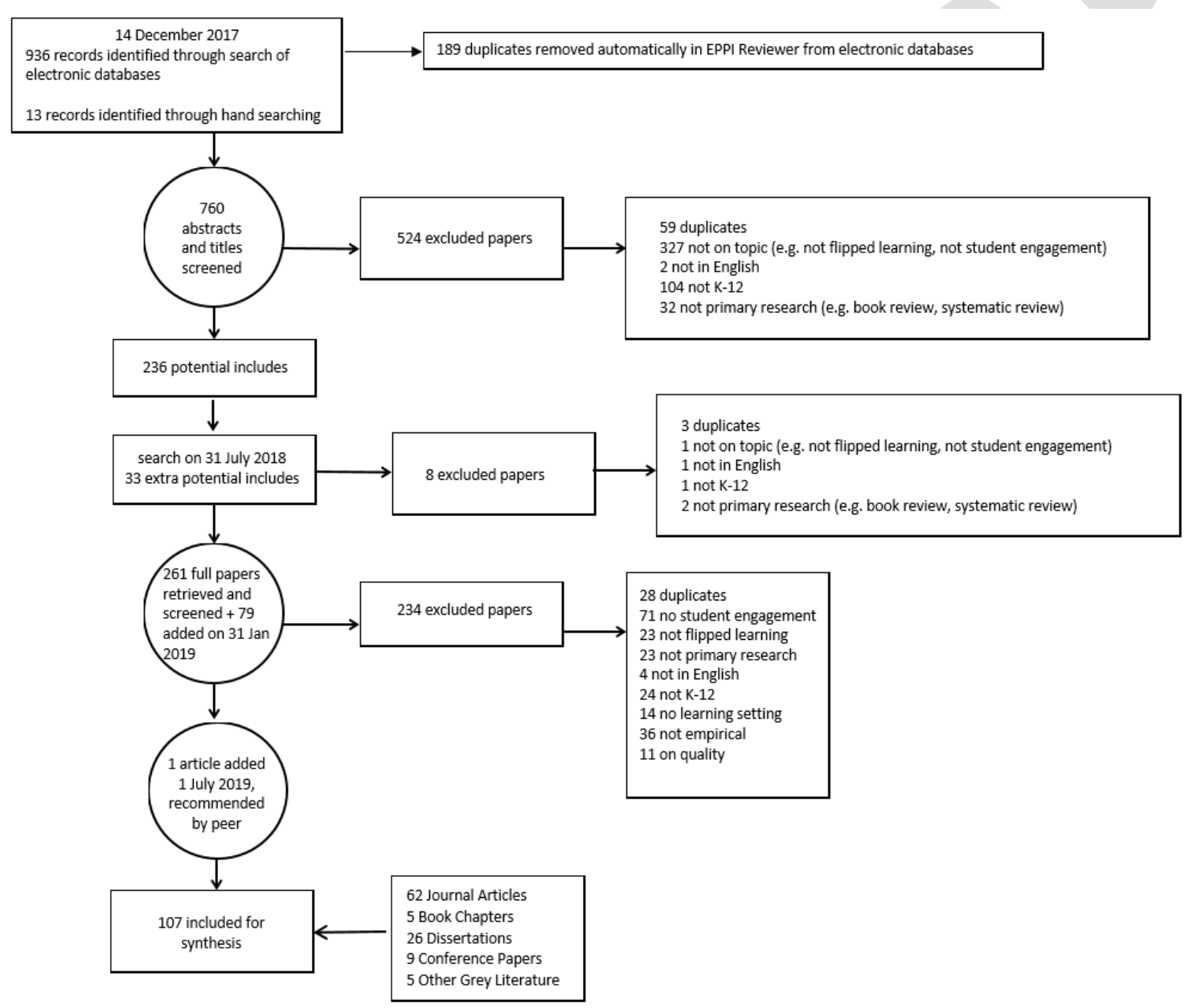

Figure 5. PRISMA flowchart (adapted from Brunton, Stansfield \& Thomas, 2012)

\section{Findings}

\subsection{Study characteristics}

The 62 journal articles included in this sample were published in 42 different journals (see Appendix D); 12 (29\%) general education journals, 15 (36\%) educational technology journals, $14(33 \%)$ discipline specific (e.g., engineering education), one methodology journal and one interdisciplinary journal. However, of the journals where multiple articles have been published $(n=10)$, seven of them are educational technology journals, with the top three journals being Educational Technology \& Society (unfortunately no longer accepting submissions), 
Computers \& Education and Journal of Computer Assisted Learning, and only one being a general education journal (Teaching and Teacher Education).

Whilst Lundin et al. (2018) noticed a substantial increase in studies on flipped learning in 2015, their review was heavily comprised of higher education studies, whereas studies in this K-12 review corpus saw an exponential rise in $2016(n=34)$, including seven doctoral dissertations. However, there was a $26 \%$ drop in publications in 2017 , with only three dissertations published in that year, and a further 12\% drop in 2018. Unfortunately Lundin et al.'s (2018) comprehensive analysis did not go past 2015 to confirm this trend and, although Tütüncü and Aksu's (2018) review included 2017 and did show a slight drop, it was focused on research in Turkey only. Further research could explore whether this is due to flipped learning being more established and therefore having less novelty factor, or whether less educators are now using the approach.

\subsubsection{Geographical characteristics}

Mirroring previous reviews (Lo \& Hew, 2017; Lundin et al., 2018), the majority of studies in this corpus were undertaken within the US $(51.40 \%, n=55)$, followed by Taiwan $(9.35 \%, n=$ 10) and Hong Kong $(7.48 \%, n=8)$. Whilst this review includes 26 dissertations, 25 of which conducted their research within the US, the percentage of studies undertaken in the US would still triple that of the next country were these to be excluded. When viewing the research contexts by continent, research in North America (54.20\%) and Asia (25.24\%) dominates, with very little research being undertaken in other parts of the world, including none from South America or the UK, and only one study from Africa, echoing previous research on the state of K-12 research within the field of educational technology (e.g. Bond et al., 2019; PérezSanagustín et al., 2017).

\subsubsection{Study design characteristics \\ 4.1.2.1 Educational settings}

The predominant educational setting was high schools, constituting $60.7 \%$ of studies $(n=65)$, with very few studies investigating kindergarten $(0.9 \%, n=1)$ or primary school contexts $(14.0 \%, n=15)$, reflecting prior educational technology (e.g., Pérez-Sanagustín et al., 2017) and flipped learning research (e.g., Lo \& Hew, 2017). Whilst nine (8.4\%) of the studies did not specify the type of school involved, they did all list the grades involved, and aside from one study focused on Year 4 students, the rest were all Year 7 focused or above, adding further weight to the high school trend. It should be noted that some of the studies included more than one type of school.

\subsubsection{Sample focus}

Students were the focus of more than half of the studies $(56.1 \%, n=60)$, followed by a combined focus on students and teachers $(27.1 \%, n=29)$. Surprisingly, only two studies included parents as participants (D'addato \& Miller, 2016; Howell, 2013) and only one study included principals (Collins, 2015). Of the 91 studies that included students, the majority (73\%) included 100 or less participants, and often focused on one, two or three classes. Of the quantitative studies that included students, $42 \%(n=18)$ focused on 51-100 students, followed by $26-50(21 \%, n=9)$ and $101-150(16 \%, n=7)$ students. Low participant numbers has been a criticism of quantitative research within the field of educational technology (PérezSanagustín et al., 2017), and this is a consideration for future research on flipped learning.

Students of school age within this sample ranged from Year 4 to Year 12, with the most frequently studied cohort being Year 9 students (32\%), followed by Year 11 students (26\%) 
and Year 8 students (22\%). This is interesting to note, given Year 9 is a difficult stage for adolescents, especially in the US - where the majority of studies were undertaken - as students are entering high school for the first time, making the transition to more difficult subject content and higher expectations (Cohen \& Smerdon, 2009). As noted by Lo and Hew (2017), Year 4 is currently the lowest grade of flipped learning research including student participants.

23 studies (25\%) included student participants across multiple year levels, with an even spread across both middle and senior secondary year levels. Three studies did not mention, or were unclear about which year level the students were in, however they did provide the students' ages; two studies with 16/17 year olds (Al-Harbi \& Alshumaimeri, 2016; Katsa, Sergis, \& Sampson, 2016) and one study with 14/15 year olds (Bhagat, Chang, \& Chang, 2016).

\subsubsection{Subjects}

Reflecting prior flipped learning research (Lo \& Hew, 2017; Lundin et al., 2018), STEM subjects (including ICT) were the most frequently studied within the corpus (see Figure 6), with Maths a particularly popular subject to research $(38.3 \%, n=41) .15$ studies included stakeholder perceptions within a variety of subjects, including Spanish, Swedish, Korean, History and Science, although the majority of these multiple subject studies were focused on teacher perceptions, rather than applications of flipped learning across subject content.

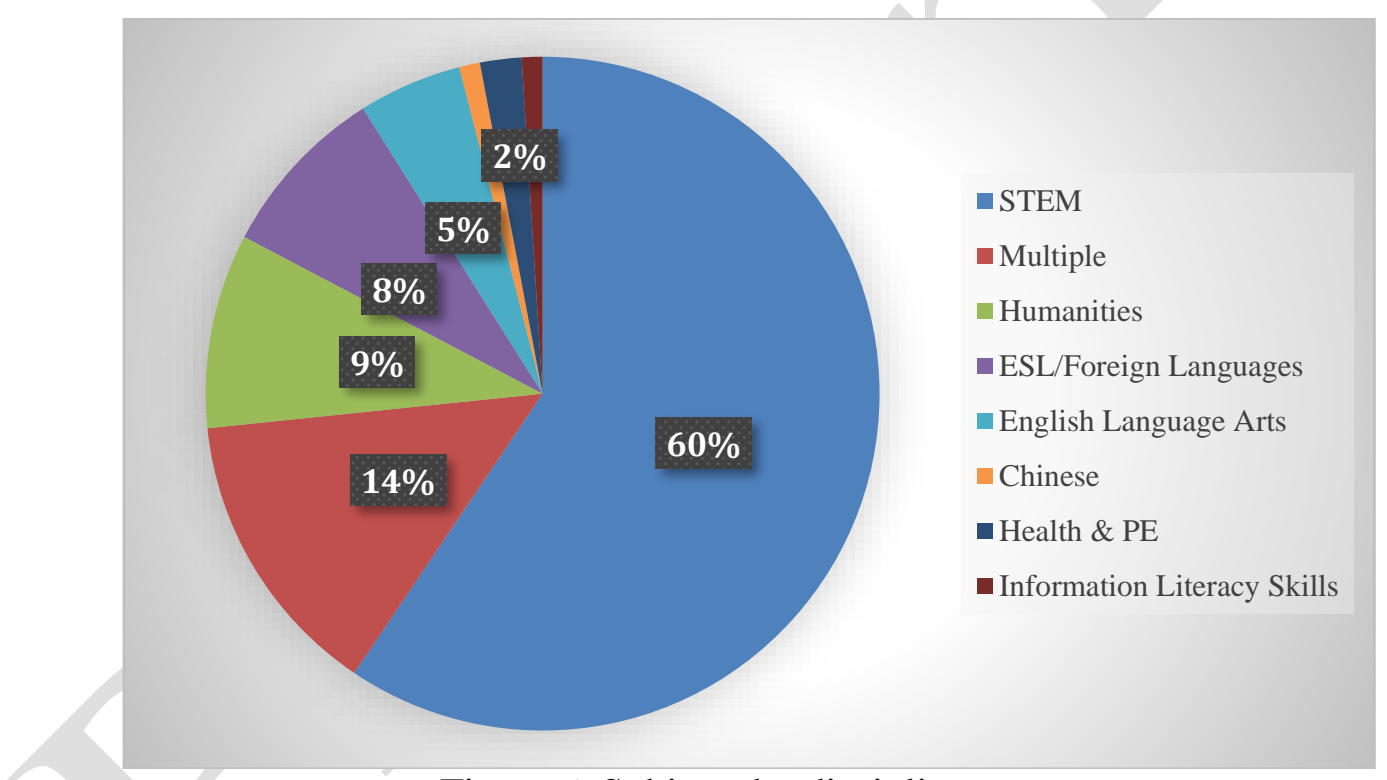

Figure 6. Subjects by discipline area

\subsubsection{Study length}

Within the sample overall, $73 \%(n=78)$ specified the study length, and of those, $90 \%$ were studies that included students. Less than half $(46 \%, n=7)$ of the studies that focused on teachers only, included details of study length. Most of the studies $(62 \%, n=48)$ were between $0-3$ months long, with many studies focused on applying flipped learning in one or two units of work. Studies that are shorter than one month invite the question as to whether there is a novelty effect, which could affect the results (Lo, 2017). Another interesting finding was that, of the 26 dissertations in the corpus, 12 included studies that were at least three months long, with eight more than 6 months long, and is a reminder that unpublished doctoral dissertations should not be discounted as valuable research (Evans, Amaro, Herbert, Blossom, \& Roberts, 2018; Maynard, Vaughn, Sarteschi, \& Berglund, 2014). 


\subsubsection{Description of 'traditional' classrooms}

Providing explicit details of interventions, including their state prior to implementation, is crucial in order to ensure greater study validity and replicability (see Hoffmann et al., 2014; Slavin, 2008). Of the 91 studies that included student participants, seven studies compared the effectiveness of a specific type of flipped learning approach (e.g. an augmented reality-based flipped approach, Chang \& Hwang, 2018) compared to a more 'conventional' flipped approach (as defined in the introduction), and one study compared the effectiveness of short versus long videos when using the flipped approach (Slemmons et al., 2018). Of the 83 studies focused on interventions using the conventional flipped approach, 55 studies $(66 \%)$ provided a description of the 'traditional' classroom, including 36 (43\%) describing the traditional teaching approach as direct instruction from the teacher during lessons, often involving 'chalk and talk' style lectures (Olakanmi, 2017). Four studies included traditional classrooms that used problembased learning activities (e.g. Kostaris et al., 2017), one study included no opportunities for peer instruction (Tsai, Shen, \& Lu, 2015), and three studies used videos within the traditional classrooms (Chen, 2016; Perrella, 2016; Sezer, 2017). Only six studies (7\%) gave explicit details about the timing and content of traditional lessons (e.g., Bhagat, Chang, \& Chang; 2016; Chao, Chen, \& Chuang, 2015; DeSantis et al., 2015), with Hodgson et al. (2017) using behavioural observations within the traditional and flipped classrooms, in order to better interpret their study results.

Controlling for pretest differences can help alleviate potential bias (Slavin, 2008), which 46 studies (43\%) did, including 30 studies measuring the impact of flipped learning on achievement (see Appendix H). In the absence of a pretest, particularly in the case of those using qualitative methods, other information should be provided about the participants and the context, to ensure transparency when interpreting results. To this end, seven studies $(8 \%)$ indicated that the students involved in flipped interventions had previously been exposed to the approach (e.g., Hunley, 2016), alongside five studies that identified particularly motivated student study participants (e.g., Weiss, 2018).

\subsubsection{Technology used}

The studies in this review used a range of technology when implementing the flipped learning approach. Unfortunately, not all studies indicated the exact technology used. For example, they may have reported the use of videos, but not specified whether they were made by the classroom teacher or whether they were made by others, or they may have mentioned an LMS, but not specified which one was used. This lack of research design information has been reported as a problem in empirical research by other reviews (e.g. Lundin et al., 2018), and can affect study reproducibility and applicability to other contexts.

As in Lo et al.'s systematic review (2017), videos made by the teacher were the most frequently used $(57.9 \%, n=62)$, whether done by screencast (e.g., Perrella, 2016), using Movie Maker (e.g., Haglind, 2016), or simply the teacher standing in front of a video camera (e.g., Jong, 2017), with far less studies reporting the use of videos made by others $(27.1 \%, n=29)$, for example on YouTube. The second most frequently used technology reported were selfassessment quizzes $(52.3 \%, n=58)$, generally undertaken by students at home, and predominantly using the quiz function in an LMS or Google Forms, followed by the use of an LMS $(51.4 \%, n=55)$. The most frequently named LMS was Edmodo $(11.2 \%, n=12)$, followed by Google Classroom and Moodle (both $9.3 \%, n=10$ ). 
In $84 \%$ of studies $(n=90)$, two or more types of technology were used to support flipped learning. In order to understand how often tools were used together (see Table 1), the formula used in Bedenlier, Bond, Buntins, Zawacki-Richter \& Kerres (2020, p. 130) was used:

In order to determine how often learning scenarios occurred together, the number of common occurrences $\left(p_{A B}\right)$ were calculated relative to the maximum possible number of common occurrences. In concrete terms, this means that in a contingency table, the cell that indicated how often two learning scenarios occurred together is used $\left(A^{+} \wedge B^{+}\right)$and the number in this cell was determined by the smaller number of respective learning scenarios $(A \wedge B)$. Expressed as a formula,

$$
p_{A B}=\frac{A^{+} \cap B^{+}}{\min \{A, B\}}
$$

Equation 1.

Only $57 \%$ of studies included quizzes where teacher-made videos were used, as opposed to $62 \%$ of studies that used videos made by others. This is quite surprising, given the finding by Van Alten et al. (2019) that embedding quizzes was critical for the successful implementation of a flipped classroom. Interestingly, $70 \%$ of studies used self-assessment quizzes where Moodle was employed as the LMS, as opposed to studies using Google Classroom (40\%), and only $62 \%$ of studies using an LMS of any kind. This indicates that teachers may need further professional development in the use of embedding quizzes into videos and/or the LMS, or increased time to be able to embed such features (Lo \& Hew, 2017).

Table 1. Co-occurrence of technology across the sample, in three or more articles

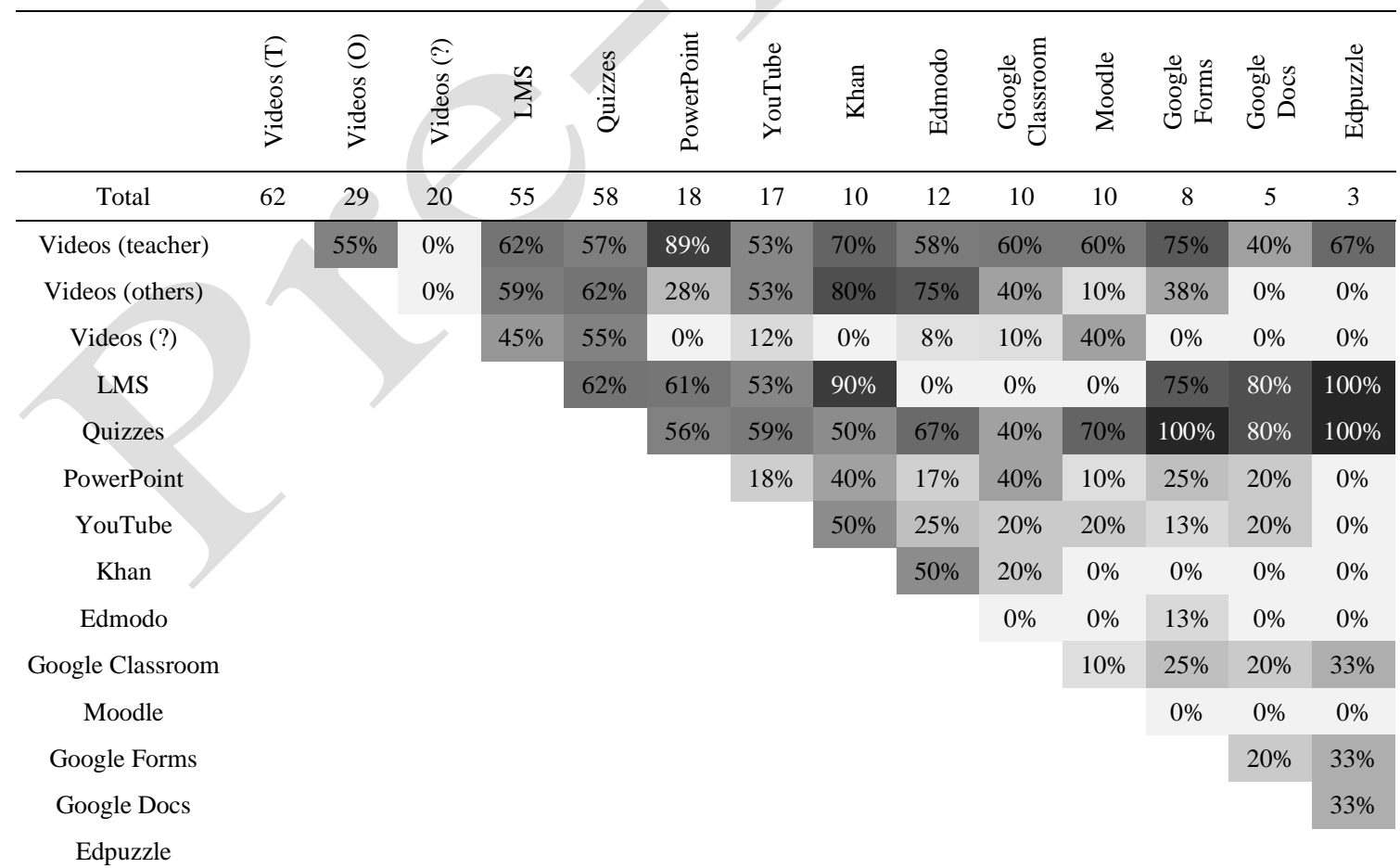

Note. Videos $(\mathrm{T})$ = videos made by the teacher; Videos $(\mathrm{O})$ = videos made by others; Videos (?) = Videos of uncertain origin; LMS numbers include those that used named LMS such as Google Classroom 


\subsubsection{Methodological characteristics and measurement of engagement}

44 studies (41\%) employed quantitative methods, 32 studies (30\%) used qualitative methods and 31 studies (29\%) used mixed methods, reflecting the findings by Low and Hew (2017) and Lundin et al. (2018). The most frequently used method were quasi-experimental studies (36\%, $n=39$ ), comparing a 'traditional' face-to-face classroom with a class using flipped learning methods, such as the study of two Year 11 engineering classes by Chao, Chen and Chuang (2015), or studies implementing the flipped approach with no control group (e.g., Kong, 2015). 23 studies (21\%) used an action research approach, 13 studies (12\%) were case studies, and 11 $(10 \%)$ were experimental/RCT studies. Given the preponderance of quantitative studies, it is then unsurprising that the most frequently used data collection tool were surveys $(68 \%, n=$ $73)$, followed by interviews $(48 \%, n=51)$ and ability tests $(45 \%, n=48)$. Given prior calls for further qualitative research when investigating flipped learning (e.g. Lundin et al., 2018), and in educational technology research in general (e.g. Pérez-Sanagustín et al., 2017), it is unsurprising that other qualitative data collection methods were used less frequently, such as observations (30\%) and focus groups (21\%).

In order to gain further insight into how student engagement was measured in studies investigating the flipped learning approach in K-12, the method used by Henrie et al. (2015) was followed (see Table 2). As in that review, student experiences of the flipped approach were measured in a number of ways, from self-report surveys to interviews and counts of student behaviour. In contrast to the Henrie et al. (2015) study, only $19 \%$ of studies used a single form of measurement, with $81 \%(n=87)$ using at least two methods. The most frequently used combination of measurements were surveys and ability tests $(34 \%, n=36)$, followed by surveys and observations $(20 \%, n=21)$ and surveys and focus groups $(19 \%, n=20)$.

Despite the lower number of qualitative studies in this sample, the number of qualitative measures used were reasonably high $(74 \%, n=79)$ using Henrie et al.'s (2015) method. This is likely due to some studies employing qualitative measures, whilst using an overall quantitative approach and methodology (e.g., Jo, Jun, \& Lim, 2018). Of the 73 studies that used surveys, 63 (86\%) included quantitative questions, for example using a Likert scale (e.g. Barlow \& Fleming, 2016), whilst 28 (38\%) included open-ended qualitative questions (e.g. Graziano \& Hall, 2017).

Table 2. Distribution of engagement measures used

\begin{tabular}{llc}
\hline Measures & Description & Frequency \\
\hline Quantitative self-report & Questionnaires/surveys or scales with quantitative items & $59 \%$ \\
Qualitative measures & $\begin{array}{l}\text { Measures that assessed engagement qualitatively, often } \\
\text { through interviews, open-ended survey questions, focus } \\
\text { groups or observations }\end{array}$ & $74 \%$ \\
Quantitative observational & $\begin{array}{l}\text { Observation that measured the frequency of behaviour, } \\
\text { measures }\end{array}$ & $\begin{array}{l}\text { or log data } \\
\text { Including assessment performance and ability tests }\end{array}$ \\
Other & & $18 \%$ \\
\hline
\end{tabular}

Of the quantitative self-report surveys, 26 (41\%) included named surveys that were used or adapted to measure engagement or aspects thereof (see Appendix F). In total, 22 named surveys were used, with the Instructional Materials Motivation Survey (Keller, 2010) the most frequently used.

\subsection{Defining student engagement in flipped learning research}

As in other reviews on educational technology and student engagement (Bond et al., 2020; Henrie et al., 2015), only 13 studies (12\%) in this corpus gave a definition of engagement (see 
Table 3), which is now considered vital for any research investigating the construct (Boekaerts, 2016). Whilst the search string used in this review did not include the term 'student engagement' or engagement terms specifically, and it is possible that the authors of studies in this sample might not have considered that the phenomenon under investigation was a component or indicator of student engagement, the term 'engagement' occurs within $23(21 \%)$ of the study titles and abstracts alone.

Of the studies that did give a definition, five defined engagement using three dimensions of engagement, namely either social or affective, cognitive and behavioural. The majority of studies defined engagement from a behavioural perspective, as active involvement or interaction with either content or learning, staying on task, exerting effort or energy, with one study (Bergstresser, 2017) taking an affective definition and one study (Hodgson, Cunningham, McGee, Kinne, \& Murphy, 2017) a combined behavioural and cognitive definition.

Table 3. Definitions of student engagement within the corpus

\begin{tabular}{|c|c|}
\hline Definition of engagement & Authors cited \\
\hline $\begin{array}{l}\text { Social, affective, cognitive or } \\
\text { behavioural dimensions }\end{array}$ & $\begin{array}{ll}\text { Abdelrahman, Dewitt, Alias, \& } & \text { Fredricks, Blumenfeld, \& Paris, } \\
\text { Abdul Rahman, 2017; Lo, 2017; } & \text { 2004; Reeve, 2013; Willms, Friesen, } \\
\text { Moran, 2018; Moran \& Young, } & \text { \& Milton, 2009 } \\
\text { 2014; Muir \& Geiger, 2016 } & \end{array}$ \\
\hline Interaction & Mullis, Martin, Foy, \& Arora, 2012 \\
\hline Active involvement & $\begin{array}{ll}\text { Aycicek \& Yelken, 2018; Collins, } & \text { Danielson, 2007; Jimerson, Campos, } \\
\text { 2015; Speller, } 2015 & \text { \& Greif, 2003; Skinner, Kindermann, } \\
& \& \text { Furrer, 2009 }\end{array}$ \\
\hline Enthusiasm for learning & Bergstresser, 2017 \\
\hline $\begin{array}{l}\text { Constant effort to reach learning } \\
\text { objectives }\end{array}$ & Abeysekera \& Dawson, 2015 \\
\hline Physical \& psychological energy & Hodgson et al., 2017 \\
\hline $\begin{array}{l}\text { Being attentive or staying on } \\
\text { task }\end{array}$ & Leo, 2017 \\
\hline
\end{tabular}

\subsection{Theoretical frameworks used in K-12 flipped learning research}

Mirroring prior educational technology research (e.g. Antonenko, 2015), only 42\% $(n=45)$ of studies in this sample used a theoretical framework. Whilst it has been recognised that there is not currently a universally recognised framework for flipped learning (Turan \& Goktas, 2016), the Flipped Learning Network developed the Four Pillars of F-L-I-P (Flexible environment, Learning culture, Intentional content and Professional educator) in 2014 (Flipped Learning Network, 2014), which have been used to frame research design, results and discussion (e.g. Muir \& Geiger, 2016).

Of those studies that used a theoretical framework (see Appendix E), 37\% ( $n=16)$ grounded their research in either a constructivist or social development theory approach, reflecting flipped learning's underpinnings (Bishop \& Verleger, 2013). The next most used theory was social cognitive theory, with these studies exploring student self-efficacy when using the flipped learning approach.

\subsection{Student engagement and flipped learning in K-12}

The 107 studies in this corpus were coded on indicators of cognitive, affective and behavioural engagement. Overall, 87 studies $(81 \%)$ provided evidence of behavioural engagement, 79 studies $(74 \%)$ resulted in affective engagement and $77(72 \%)$ in cognitive engagement, with 61 studies $(57 \%)$ resulting in all three engagement dimensions. The five most frequently cited indicators of engagement were increased interaction with peers, enjoyment, 
participation/involvement, increased interaction with teachers and increased confidence (see Table 4).

Table 4. Top five engagement indicators across the three dimensions

\begin{tabular}{|c|c|c|c|c|c|c|c|c|c|}
\hline Rank & Behavioural Eng. & $n$ & $\%$ & Affective Eng. & $n$ & $\%$ & Cognitive Eng. & $n$ & $\%$ \\
\hline 1 & $\begin{array}{l}\text { Increased interaction } \\
\text { with peers }\end{array}$ & 50 & $47 \%$ & Enjoyment & 42 & $39 \%$ & $\begin{array}{l}\text { Positive self- } \\
\text { perceptions \& self- } \\
\text { efficacy }\end{array}$ & 30 & $28 \%$ \\
\hline 2 & $\begin{array}{l}\text { Participation/involve } \\
\text { ment }\end{array}$ & 39 & $36 \%$ & $\begin{array}{l}\text { Positive interactions } \\
\text { with peers }\end{array}$ & 25 & $23 \%$ & Self-regulation & 25 & $23 \%$ \\
\hline 3 & $\begin{array}{l}\text { Increased interaction } \\
\text { with teachers }\end{array}$ & 37 & $35 \%$ & Interest & 23 & $21 \%$ & Understanding & 24 & $22 \%$ \\
\hline 4 & Confidence & 33 & $31 \%$ & Enthusiasm & 15 & $14 \%$ & Learning from peers & 23 & $21 \%$ \\
\hline 5 & $\begin{array}{l}\text { Study habits / } \\
\text { Assuming } \\
\text { responsibility }\end{array}$ & 21 & $20 \%$ & $\begin{array}{l}\text { Positive interactions } \\
\text { with teachers }\end{array}$ & 13 & $12 \%$ & Focus/concentrate & 20 & $19 \%$ \\
\hline
\end{tabular}

26 studies (24\%) found that flipped learning enhanced engagement overall, but did not specify which indicators and/or dimensions this referred to. These were coded separately to the other indicators. For example, whilst Aycicek and Yelken (2018) used the 'Classroom Engagement Inventory' developed by Wang et al. (2014) in their study of Year 7 English as a Second Language (ESL) students, the results were presented as affective, cognitive or behavioural engagement, with no indication which specific indicators were being measured, aside from effort. However, whilst there was no significant difference between the experimental flipped learning group and the control group, there was a rise in affective and cognitive engagement post-test scores, which were higher than the control group. Another example is the study of Year 4 ESL students in Malaysia by Teo and Sathappan (2018), whose Likert survey included the statement 'Flipped Classroom Approach is more engaging than the lessons I had before', to which 70\% $(n=7)$ agreed and 30\% $(n=3)$ strongly agreed. Qualitative studies were coded engagement when students expressed statements such as "overall I feel more engaged in the lesson and at the same time, (it) ignited my passion in studying hard for the subject" (Chan, 2016, p. 1304), or when teachers said something like "I cannot say that flipped learning has been solely responsible for increased achievement, but I can say it has increased my student engagement in my classroom which...has resulted in higher achievement" (Oyola, 2016, p. 71).

In order to gain further insight into how various technologies used in flipped learning studies are linked to engagement, a co-occurrence analysis was undertaken between technology and the instances of overall behavioural, affective and cognitive engagement (see Table 5). The analysis revealed that $100 \%(n=10)$ of studies using Google Classroom, and 92\% $(n=11)$ of studies using Edmodo reported behavioural engagement, compared to only 70\% $(n=16)$ of studies that used other LMS. Videos that were created by other people, such as researchers or YouTube clips, reported engagement across all three domains, slightly higher than that of videos created by teachers. However, there were twice the amount of teacher-made videos, and to gain a more nuanced understanding of the link between technology used in flipped learning research and engagement, each domain requires individual analysis. 
Table 5. Relative frequency of studies using technology and student engagement domains

\begin{tabular}{lccccccccccc}
\hline & $\begin{array}{c}\text { Videos } \\
\text { (teacher) }\end{array}$ & $\begin{array}{c}\text { Videos } \\
\text { (others) }\end{array}$ & $\begin{array}{c}\text { Videos } \\
(?)\end{array}$ & $\begin{array}{c}\text { You } \\
\text { Tube }\end{array}$ & Khan & LMS & $\begin{array}{c}\text { Other } \\
\text { LMS }\end{array}$ & Edmodo & GC & Moodle & Quizzes \\
\hline$n=62$ & $n=29$ & $n=20$ & $n=17$ & $n=10$ & $n=55$ & $n=23$ & $n=12$ & $n=10$ & $n=10$ & $n=58$ \\
\hline $\begin{array}{l}\text { Behavioural } \\
\text { Engagement }\end{array}$ & $87 \%$ & $93 \%$ & $70 \%$ & $82 \%$ & $80 \%$ & $80 \%$ & $70 \%$ & $92 \%$ & $100 \%$ & $80 \%$ & $76 \%$ \\
$\begin{array}{l}\text { Affective } \\
\text { Engagement }\end{array}$ & $73 \%$ & $86 \%$ & $75 \%$ & $76 \%$ & $70 \%$ & $82 \%$ & $78 \%$ & $83 \%$ & $90 \%$ & $90 \%$ & $74 \%$ \\
$\begin{array}{l}\text { Cognitive } \\
\text { Engagement }\end{array}$ & $69 \%$ & $83 \%$ & $75 \%$ & $65 \%$ & $70 \%$ & $69 \%$ & $65 \%$ & $83 \%$ & $70 \%$ & $70 \%$ & $74 \%$ \\
\hline
\end{tabular}

Note ? = uncertain origin; LMS numbers include those that used named LMS such as Google Classroom; Other LMS = LMS not including Edmodo, Google Classroom or Moodle; GC = Google Classroom

\subsubsection{Behavioural engagement and flipped learning}

The most frequently reported dimension of engagement - but also arguably the most frequently measured - was behavioural engagement, with 14 different indicators identified as a result of flipped learning (see Table 4 for the top five). By far the most cited instance of behavioural engagement was increased interaction between peers $(47 \%, n=50)$, with a number of studies that used classroom observations within flipped classes reporting a significant increase, compared to those using traditional methods (e.g., Chen, 2016; Johnson \& Renner, 2012). Students identified that flipped learning helped to improve how they participated within the classroom (Abdelrahman et al., 2017; Olakanmi, 2017), including more equitable interactions between students, with quieter students finding courage - and likewise being encouraged - to engage in discussions (Collins, 2015; Grypp \& Luebeck, 2015). Teachers found these peer interactions particularly valuable, as they made student knowledge more visible (Bäcklund \& Hugo, 2018), including student use of subject-specific terminology (de Araujo, Otten, \& Birisci, 2017; Parham, 2018). Studies also reported increased collaboration occurring outside of school, through social media, email or text messaging (Strohmyer, 2016; Wiginton, 2014), with high school teachers in a three year study finding Google Docs to be particularly good at facilitating within and between group discussions (Kong, 2015). An analysis of the cooccurrence of behavioural engagement indicators and different technology used within the sample (see Table 6) also revealed that LMS such as Google Classroom, Moodle and Edmodo afforded increased collaborative opportunities between students, as increased interaction with peers occurred in $60 \%$ of studies, as opposed to $26 \%(n=6)$ of studies using another LMS ( $n$ $=23$ ).

As reported in other reviews (Lo \& Hew, 2017; Tütüncü \& Aksu, 2018), flipped learning promoted more active learning (participation/involvement) within the classroom, with teachers reporting students coming to class prepared (study habits) and asking more questions as a result of having seen the content prior to lessons (Bäcklund \& Hugo, 2018; Ronnebaum, 2018). One Year 11 Engineering student explained that the flipped approach "made [him/her] feel like learning, since [the students] are the focus of the class" and so they participated actively, rather than "sitting there listening to what the teacher says" (Chao et al., 2015, p. 522). Teachers reported students voluntarily re-watching videos, taking notes or searching for content (Hodgson et al., 2017; Hulten \& Larsson, 2018), with students who had been "used to [a] passive learning attitude" (High school Maths teacher, Lo, Lie, \& Hew, 2018, p. 161) starting to ask questions and display curiosity (Yang, 2017). This also then fostered more responsibility, as students became increasingly aware that active learning and participation meant needing to "become a more independent person" (Year 11 student, Avery, Huggan, \& Preston, 2018, p. 9) and take ownership of their learning, with evidence of this even within a Year 4 Maths class (D'addato \& Miller, 2016). 
Table 6. Relative frequency of behavioural engagement indicators by technology (in three or more articles)

\begin{tabular}{|c|c|c|c|c|c|c|c|c|c|c|c|c|c|c|c|}
\hline & $\begin{array}{l}\hat{E} \\
0 \\
0 \\
: 0 \\
j\end{array}$ & 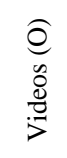 & 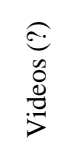 & $\sum_{=}^{\infty}$ & 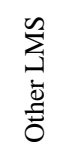 & $\begin{array}{l}\mathscr{U} \\
\stackrel{N}{Z} \\
\ddot{0}\end{array}$ & 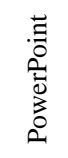 & $\begin{array}{l}\stackrel{0}{\Xi} \\
\stackrel{\Xi}{\Xi} \\
0 \\
己\end{array}$ & 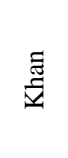 & $\begin{array}{l}\stackrel{0}{0} \\
\text { O } \\
\text { I }\end{array}$ & 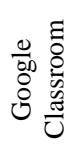 & $\begin{array}{l}\frac{0}{\partial} \\
\stackrel{0}{\Sigma}\end{array}$ & $\begin{array}{l}\frac{0}{0.0} \\
0 \\
0 \\
0 \\
0\end{array}$ & $\begin{array}{l}\tilde{O} \\
0 \\
0 \\
0 \\
00 \\
0 \\
0 \\
0\end{array}$ & 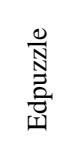 \\
\hline Sum & 62 & 29 & 20 & 55 & 23 & 58 & 18 & 17 & 10 & 12 & 10 & 10 & 8 & 5 & 3 \\
\hline $\begin{array}{l}\text { Increased interaction } \\
\text { with peers }\end{array}$ & $48 \%$ & $62 \%$ & $40 \%$ & $44 \%$ & $26 \%$ & $47 \%$ & $61 \%$ & $41 \%$ & $50 \%$ & $58 \%$ & $60 \%$ & $60 \%$ & $50 \%$ & $60 \%$ & $33 \%$ \\
\hline $\begin{array}{l}\text { Participation/Involve } \\
\text { ment }\end{array}$ & $34 \%$ & $45 \%$ & $40 \%$ & $35 \%$ & $26 \%$ & $34 \%$ & $28 \%$ & $47 \%$ & $30 \%$ & $42 \%$ & $60 \%$ & $30 \%$ & $38 \%$ & $40 \%$ & $33 \%$ \\
\hline $\begin{array}{l}\text { Increased interaction } \\
\text { with teacher }\end{array}$ & $42 \%$ & $52 \%$ & $25 \%$ & $38 \%$ & $22 \%$ & $33 \%$ & $44 \%$ & $41 \%$ & $60 \%$ & $58 \%$ & $50 \%$ & $50 \%$ & $50 \%$ & $20 \%$ & $0 \%$ \\
\hline Confidence & $29 \%$ & $34 \%$ & $45 \%$ & $29 \%$ & $9 \%$ & $33 \%$ & $39 \%$ & $35 \%$ & $30 \%$ & $33 \%$ & $60 \%$ & $50 \%$ & $25 \%$ & $20 \%$ & $33 \%$ \\
\hline Study habits & $23 \%$ & $28 \%$ & $10 \%$ & $18 \%$ & $22 \%$ & $34 \%$ & $33 \%$ & $18 \%$ & $30 \%$ & $17 \%$ & $20 \%$ & $10 \%$ & $50 \%$ & $20 \%$ & $33 \%$ \\
\hline $\begin{array}{l}\text { Assuming } \\
\text { responsibility }\end{array}$ & $23 \%$ & $28 \%$ & $20 \%$ & $20 \%$ & $17 \$$ & $19 \%$ & $28 \%$ & $24 \%$ & $40 \%$ & $33 \%$ & $20 \%$ & $20 \%$ & $25 \%$ & $20 \%$ & $33 \%$ \\
\hline $\begin{array}{l}\text { Homework } \\
\text { completion }\end{array}$ & $21 \%$ & $24 \%$ & $0 \%$ & $15 \%$ & $9 \%$ & $19 \%$ & $44 \%$ & $12 \%$ & $0 \%$ & $25 \%$ & $30 \%$ & $10 \%$ & $25 \%$ & $40 \%$ & $33 \%$ \\
\hline $\begin{array}{l}\text { Time on task/staying } \\
\text { on task/persistence }\end{array}$ & $15 \%$ & $21 \%$ & $10 \%$ & $15 \%$ & $9 \%$ & $14 \%$ & $17 \%$ & $12 \%$ & $20 \%$ & $25 \%$ & $10 \%$ & $20 \%$ & $0 \%$ & $0 \%$ & $0 \%$ \\
\hline $\begin{array}{l}\text { Asking peers or } \\
\text { teacher for help }\end{array}$ & $13 \%$ & $14 \%$ & $5 \%$ & $4 \%$ & $0 \%$ & $10 \%$ & $28 \%$ & $12 \%$ & $10 \%$ & $17 \%$ & $0 \%$ & $0 \%$ & $13 \%$ & $0 \%$ & $0 \%$ \\
\hline Effort & $8 \%$ & $7 \%$ & $5 \%$ & $9 \%$ & $4 \%$ & $5 \%$ & $5 \%$ & $0 \%$ & $10 \%$ & $8 \%$ & $20 \%$ & $10 \%$ & $38 \%$ & $20 \%$ & $33 \%$ \\
\hline Positive conduct & $8 \%$ & $17 \%$ & $0 \%$ & $13 \%$ & $0 \%$ & $9 \%$ & $11 \%$ & $12 \%$ & $20 \%$ & $25 \%$ & $10 \%$ & $0 \%$ & $0 \%$ & $0 \%$ & $0 \%$ \\
\hline Attention/focus & $5 \%$ & $7 \%$ & $10 \%$ & $2 \%$ & $0 \%$ & $7 \%$ & $5 \%$ & $6 \%$ & $0 \%$ & $0 \%$ & $0 \%$ & $10 \%$ & $0 \%$ & $0 \%$ & $0 \%$ \\
\hline $\begin{array}{l}\text { Interaction with } \\
\text { content }\end{array}$ & $8 \%$ & $10 \%$ & $0 \%$ & $5 \%$ & $4 \%$ & $7 \%$ & $11 \%$ & $12 \%$ & $0 \%$ & $17 \%$ & $0 \%$ & $0 \%$ & $0 \%$ & $0 \%$ & $0 \%$ \\
\hline
\end{tabular}

Note. Videos $(\mathrm{T})=$ videos made by the teacher; Videos $(\mathrm{O})=$ videos made by others; Videos (?) = Videos of uncertain origin; LMS numbers include those that used named LMS such as Google Classroom

With more collaborative activities happening in the group space, and instruction moved to the individual space, opportunities increased for students to interact with the teacher. Teachers reported having more time to devote to individual students or small groups (Hunley, 2016), with one Year 6 Maths teacher stating that "class time is more vibrant" (Ripley, 2015, p. 108). In one classroom (Unruh et al., 2016), for example, the teacher was observed interacting with 15 out of 18 students during the lesson. This increased opportunity to talk to students and provide formative feedback gave some teachers the feeling that they knew their students better and knew "where they were academically" (Year 5 Maths teacher, Wiley, 2015, p. 64) as a result. Students likewise felt that teachers were more accessible, with one Year 12 student describing it as a change in culture, with a more equal relationship between the teacher and students (Strohmyer, 2016). Interestingly, instances of increased interaction with the teacher were slightly higher in studies where videos were created by someone other than the teacher $(52 \%)$, than when they were made by the teacher $(42 \%)$. This could be due, however, to students needing further guidance or clarification from their teachers, as the videos created by others included different terminology or concepts than what they were used to (e.g., Ramaglia, 2015; Weiss, 2018).

\subsubsection{Affective engagement and flipped learning}

The flipped learning approach had a positive effect on 13 different indicators of affective engagement in this corpus (see Table 4 for the top five). Of these, enjoyment was by far the most cited affective indicator $(39 \%, n=42)$ and the second highest indicator overall. A lot of this was due to the novelty of watching videos, described as fun and interactive in a number of studies (e.g., Barlow \& Fleming, 2016; Brooks \& Weaver, 2017), with the co-occurrence analysis revealing that students particularly enjoyed using Khan Academy, YouTube and when 
teachers used PowerPoint to screencast their videos (see Table 7). Student enjoyment also stemmed from working with peers (Olakanmi, 2017; Wiley, 2015), teaching self and peers (Wiginton, 2014), using online collaborative tools such as Google Classroom (Strydom, 2017) and doing homework at school instead of at home (Smith, 2016). In particular, students enjoyed the freedom of being able to work at their own pace (Sharpe, 2016) and to be able to re-watch videos as often as needed (Abdul et al., 2017). For some students, the approach reduced their anxiety and stress (Carlisle, 2018) and increased their subject enjoyment (e.g., Esperanza, Fabian, \& Toto, 2016), with one middle school student stating that "in the flipped classroom, I am different. I realised for the first time that learning was a pleasure" (Lee, 2018, p. 849).

Table 7. Relative frequency of affective engagement indicators by technology (in three or more articles)

\begin{tabular}{|c|c|c|c|c|c|c|c|c|c|c|c|c|c|c|c|}
\hline & 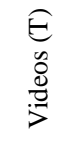 & $\begin{array}{l}\widehat{0} \\
\tilde{0} \\
0 \\
: 0 \\
j\end{array}$ & 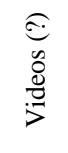 & $\sum_{-1}^{\infty}$ & $\begin{array}{l}\sum_{J}^{\infty} \\
\bar{\Xi} \\
\stackrel{5}{0}\end{array}$ & $\begin{array}{l}\stackrel{0}{N} \\
\stackrel{N}{\Xi}\end{array}$ & 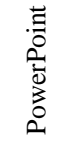 & $\begin{array}{l}\stackrel{0}{0} \\
\stackrel{\Xi}{\Xi} \\
\stackrel{0}{\Xi}\end{array}$ & Еี & $\begin{array}{l}\stackrel{0}{0} \\
\stackrel{0}{0} \\
\stackrel{Z}{0}\end{array}$ & 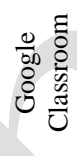 & $\begin{array}{l}\frac{0}{0} \\
\frac{8}{2}\end{array}$ & $\begin{array}{l}\frac{0}{00} \\
O \\
0 \\
0 \\
0\end{array}$ & $\begin{array}{l}\tilde{O} \\
0 \\
0 \\
0 \\
0 \\
0 \\
0 \\
0\end{array}$ & 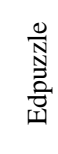 \\
\hline Sum & 62 & 29 & 20 & 55 & 23 & 58 & 18 & 17 & 10 & 12 & 10 & 10 & 8 & 5 & 3 \\
\hline Enjoyment & $40 \%$ & $52 \%$ & $25 \%$ & $45 \%$ & $35 \%$ & $41 \%$ & $61 \%$ & $59 \%$ & $60 \%$ & $33 \%$ & $80 \%$ & $60 \%$ & $25 \%$ & $20 \%$ & $33 \%$ \\
\hline Excitement & $8 \%$ & $14 \%$ & $15 \%$ & $11 \%$ & $9 \%$ & $10 \%$ & $6 \%$ & $12 \%$ & $10 \%$ & $25 \%$ & $10 \%$ & $0 \%$ & $25 \%$ & $20 \%$ & $33 \%$ \\
\hline Enthusiasm & $15 \%$ & $24 \%$ & $15 \%$ & $13 \%$ & $4 \%$ & $17 \%$ & $11 \%$ & $24 \%$ & $10 \%$ & $33 \%$ & $20 \%$ & $10 \%$ & $13 \%$ & $0 \%$ & $0 \%$ \\
\hline Pride & $3 \%$ & $7 \%$ & $10 \%$ & $7 \%$ & $4 \%$ & $7 \%$ & $6 \%$ & $12 \%$ & $10 \%$ & $17 \%$ & $10 \%$ & $0 \%$ & $0 \%$ & $0 \%$ & $0 \%$ \\
\hline $\begin{array}{l}\text { Positive interactions } \\
\text { with the teacher }\end{array}$ & $13 \%$ & $21 \%$ & $15 \%$ & $16 \%$ & $9 \%$ & $9 \%$ & $11 \%$ & $12 \%$ & $10 \%$ & $33 \%$ & $20 \%$ & $10 \%$ & $25 \%$ & $0 \%$ & $0 \%$ \\
\hline $\begin{array}{l}\text { Positive interactions } \\
\text { with peers }\end{array}$ & $21 \%$ & $34 \%$ & $20 \%$ & $24 \%$ & $4 \%$ & $26 \%$ & $33 \%$ & $24 \%$ & $30 \%$ & $42 \%$ & $50 \%$ & $30 \%$ & $25 \%$ & $20 \%$ & $67 \%$ \\
\hline Sense of wellbeing & $6 \%$ & $7 \%$ & $10 \%$ & $5 \%$ & $4 \%$ & $7 \%$ & $11 \%$ & $12 \%$ & $10 \%$ & $17 \%$ & $0 \%$ & $0 \%$ & $0 \%$ & $0 \%$ & $0 \%$ \\
\hline $\begin{array}{l}\text { Positive attitude } \\
\text { towards learning }\end{array}$ & $11 \%$ & $28 \%$ & $0 \%$ & $11 \%$ & $13 \%$ & $10 \%$ & $6 \%$ & $12 \%$ & $20 \%$ & $8 \%$ & $20 \%$ & $0 \%$ & $13 \%$ & $0 \%$ & $0 \%$ \\
\hline Interest & $13 \%$ & $21 \%$ & $30 \%$ & $16 \%$ & $22 \%$ & $21 \%$ & $11 \%$ & $24 \%$ & $0 \%$ & $8 \%$ & $10 \%$ & $20 \%$ & $13 \%$ & $20 \%$ & $0 \%$ \\
\hline Curiosity & $3 \%$ & $3 \%$ & $5 \%$ & $4 \%$ & $4 \%$ & $3 \%$ & $11 \%$ & $6 \%$ & $10 \%$ & $8 \%$ & $0 \%$ & $0 \%$ & $0 \%$ & $0 \%$ & $0 \%$ \\
\hline Sees relevance & $3 \%$ & $3 \%$ & $15 \%$ & $7 \%$ & $4 \%$ & $5 \%$ & $0 \%$ & $0 \%$ & $0 \%$ & $0 \%$ & $10 \%$ & $20 \%$ & $13 \%$ & $20 \%$ & $33 \%$ \\
\hline Satisfaction & $6 \%$ & $0 \%$ & $15 \%$ & $5 \%$ & $0 \%$ & $5 \%$ & $0 \%$ & $0 \%$ & $0 \%$ & $0 \%$ & $10 \%$ & $20 \%$ & $0 \%$ & $0 \%$ & $0 \%$ \\
\hline
\end{tabular}

Note. Videos $(\mathrm{T})=$ videos made by the teacher; Videos $(\mathrm{O})=$ videos made by others; Videos (?) = Videos of uncertain origin; LMS numbers include those that used named LMS such as Google Classroom

An indicator particularly linked with enjoyment was positive interactions with peers, which was coded in $23 \%(n=25)$ of studies, and likewise the cognitive indicators learning from peers and teaching self \& peers (e.g., Cukurbasi \& Kiyici, 2018). Students described the explanations and support of their classmates as "one of the most helpful aspects of the flipped classes" (AlHarbi \& Alshumaimeri, 2016, p. 68), as they could draw on the "'expanded brain power' that emerges from collaboration" (Grypp \& Luebeck, 2015, p. 191). For some, this led to "a true understanding of each other allowing [them] to work amongst each other even better" (Year 12 Social Studies student, Lazarus, 2018, p. 95), with noticeable improvements in classroom atmosphere (Speller, 2015) and collegiality (D'addato \& Miller, 2016). Frequently reported, too, were positive interactions with teachers and strengthened attitudes towards teachers (e.g., Chao et al., 2015). Aside from a general teacher-student rapport (e.g., Speller, 2015), students discussed how the flipped approach built trust in their teacher. One Year 11 student trusted their teacher more as a result of the teacher-created videos "because she realised her teacher was a real person outside of the school environment" (Avery et al., 2018, p. 12), and a Year 12 student realised that their teacher "expected [them] to be more responsible for the learning" 
(Strohmyer, 2016, p. 145), and the student then had to put their trust in their teacher's faith, that they had the ability to meet those higher expectations.

The variety of activities able to be undertaken within the classroom as a result of flipped learning, as well as the videos, increased students' interest in subject content and learning (Lee, 2018; Pengfei \& Mingxuan, 2016; Song \& Kapur, 2017), with one senior student stating "I often find myself prioritising math over other subjects" (Chan, 2016, p. 1304). Flipped classrooms that also utilised game-based learning were particularly interesting for students (Jo, Jun, \& Lim, 2018; Tao, Huang, \& Tsai, 2017; Ye, Hsiao, \& Sun, 2018), as was creating their own videos for peers (Jong, 2017). Rontogiannis (2014) noted that, even though there was no significant change in students' grades in their study of Year 8 Science, student feedback via open ended questions in surveys and informal discussions indicated that both their motivation and interest had been increased, and the hands-on activities within the group space was "the highlight of their learning" (p. 741). Had this study not included qualitative measures, this affective engagement would have been disregarded, and the outcomes of the study might not have provided the whole picture.

\subsubsection{Cognitive engagement and flipped learning}

Found slightly less in the studies in this review, cognitive engagement was coded through 12 different indicators (see Table 4 for the top five), with the flipped learning approach enhancing positive self-perceptions \& self-efficacy in more than a quarter of studies, and found in $50 \%$ of studies using Google Classroom (see Table 8). Research reported enhanced student subject self-efficacy (Abdelrahman et al., 2017; Chaipidech \& Srisawasdi, 2016) and technology selfefficacy (Chang \& Hwang, 2018; Huang \& Hong, 2016), with Hwang and Lai (2017) finding that a flipped learning approach using an interactive eBook was more effective for students with lower self-efficacy. Again, whilst some students did not obtain higher results in exams using the flipped approach, they were "not disappointed" because they "became more confident" and "more comfortable to pose questions to the teachers and friends" (Middle school student, Lee, 2018, p. 850). There was, however, still quite a number of studies that reported increased content understanding (e.g., Kong, 2015), even if only in one aspect or topic of instruction more than others (e.g., Kirvan, Rakes, \& Zamora, 2015).

With increased self-efficacy, also came increased self-regulation, which was an unanticipated outcome for some teachers (e.g., Howell, 2013). Whilst it took time for students to become familiar with the approach, gradually students increasingly developed more independent learning skills and reflection (Kong, 2014), and realised that just watching the videos was also not enough (Bäcklund \& Hugo, 2018). Parents noticed this increased independence in a study of Year 4 Maths students (D'addato \& Miller, 2016), with one parent commenting that flipped learning "increases rigour and level of engagement" (p. 40), and 93\% $(n=25)$ of students in the study indicated that they would seek help from maths websites on their own first, if they were having trouble with an assignment. However, Brooks and Weaver (2017) found a pronounced variation in their Year 7 English Language Arts students' ability to self-regulate, with many students needing more scaffolding than was expected, and they question the capability of middle school students to cope with the flipped approach as envisioned by Bergmann and Sams (2012). 
Table 8. Relative frequency of cognitive engagement indicators by technology (in three or more articles)

\begin{tabular}{|c|c|c|c|c|c|c|c|c|c|c|c|c|c|c|c|}
\hline & 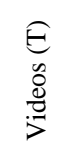 & $\begin{array}{l}\text { o } \\
\tilde{0} \\
\frac{d}{0} \\
i=\end{array}$ & 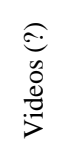 & $\sum_{-1}^{\infty}$ & 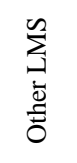 & $\begin{array}{l}\stackrel{\mathscr{N}}{N} \\
\stackrel{N}{\Xi}\end{array}$ & 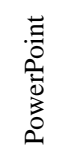 & 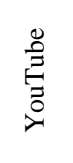 & 胥 & $\begin{array}{l}\frac{O}{0} \\
\stackrel{O}{\Xi} \\
\text { 니 }\end{array}$ & 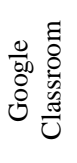 & 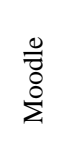 & $\begin{array}{l}\frac{0}{00} \\
0 \\
0 \\
0 \\
0 \\
0\end{array}$ & $\begin{array}{l}0 \\
0 \\
0 \\
0 \\
00 \\
0 \\
0 \\
0\end{array}$ & 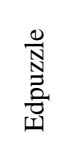 \\
\hline Sum & 62 & 29 & 20 & 55 & 23 & 58 & 18 & 17 & 10 & 12 & 10 & 10 & 8 & 5 & 3 \\
\hline $\begin{array}{l}\text { Positive self- } \\
\text { perceptions \& self- } \\
\text { efficacy }\end{array}$ & $21 \%$ & $38 \%$ & $30 \%$ & $27 \%$ & $22 \%$ & $28 \%$ & $28 \%$ & $29 \%$ & $40 \%$ & $33 \%$ & $50 \%$ & $20 \%$ & $13 \%$ & $20 \%$ & $33 \%$ \\
\hline Self-regulation & $27 \%$ & $31 \%$ & $5 \%$ & $24 \%$ & $30 \%$ & $21 \%$ & $28 \%$ & $29 \%$ & $40 \%$ & $25 \%$ & $20 \%$ & $10 \%$ & $25 \%$ & $0 \%$ & $33 \%$ \\
\hline Understanding & $21 \%$ & $24 \%$ & $20 \%$ & $20 \%$ & $22 \%$ & $21 \%$ & $33 \%$ & $29 \%$ & $40 \%$ & $17 \%$ & $30 \%$ & $10 \%$ & $25 \%$ & $40 \%$ & $33 \%$ \\
\hline Learning from peers & $24 \%$ & $38 \%$ & $20 \%$ & $18 \%$ & $9 \%$ & $28 \%$ & $39 \%$ & $24 \%$ & $30 \%$ & $17 \%$ & $40 \%$ & $30 \%$ & $50 \%$ & $20 \%$ & $33 \%$ \\
\hline Focus/concentrate & $19 \%$ & $17 \%$ & $20 \%$ & $18 \%$ & $17 \%$ & $22 \%$ & $17 \%$ & $18 \%$ & $20 \%$ & $17 \%$ & $10 \%$ & $30 \%$ & $0 \%$ & $20 \%$ & $0 \%$ \\
\hline Critical thinking & $8 \%$ & $17 \%$ & $25 \%$ & $20 \%$ & $26 \%$ & $22 \%$ & $6 \%$ & $18 \%$ & $10 \%$ & $17 \%$ & $20 \%$ & $10 \%$ & $25 \%$ & $80 \%$ & $33 \%$ \\
\hline Teaching self $\&$ peers & $19 \%$ & $31 \%$ & $10 \%$ & $18 \%$ & $17 \%$ & $16 \%$ & $28 \%$ & $24 \%$ & $30 \%$ & $17 \%$ & $40 \%$ & $10 \%$ & $38 \%$ & $0 \%$ & $0 \%$ \\
\hline Deep learning & $13 \%$ & $14 \%$ & $15 \%$ & $13 \%$ & $13 \%$ & $16 \%$ & $17 \%$ & $18 \%$ & $10 \%$ & $17 \%$ & $10 \%$ & $10 \%$ & $0 \%$ & $20 \%$ & $0 \%$ \\
\hline Reflection & $10 \%$ & $10 \%$ & $5 \%$ & $4 \%$ & $9 \%$ & $3 \%$ & $6 \%$ & $0 \%$ & $0 \%$ & $0 \%$ & $0 \%$ & $0 \%$ & $0 \%$ & $20 \%$ & $0 \%$ \\
\hline Setting learning goals & $6 \%$ & $3 \%$ & $5 \%$ & $4 \%$ & $4 \%$ & $3 \%$ & $0 \%$ & $0 \%$ & $0 \%$ & $8 \%$ & $0 \%$ & $0 \%$ & $0 \%$ & $0 \%$ & $0 \%$ \\
\hline $\begin{array}{l}\text { Preference for } \\
\text { challenging tasks }\end{array}$ & $3 \%$ & $3 \%$ & $0 \%$ & $2 \%$ & $0 \%$ & $3 \%$ & $0 \%$ & $0 \%$ & $0 \%$ & $0 \%$ & $10 \%$ & $0 \%$ & $13 \%$ & $20 \%$ & $33 \%$ \\
\hline
\end{tabular}

20 studies found that students were able to better focus/concentrate as a result of flipped learning. For example, in a two month quasi-experimental study of senior Maths students (Katsa et al., 2016), an experimental group using the flipped approach $(\mathrm{M}=4.31, \mathrm{SD}=0.47)$ scored considerably higher than the traditional control group $(\mathrm{M}=3.65, \mathrm{SD}=0.54)$ for attention. In some cases, students found that it was easier to concentrate with the videos as they were more engaging (Muir \& Geiger, 2016) and they could watch them uninterrupted (Muir, 2016). However, in their large-scale two year study of middle school Science classes, Slemmons et al. (2018) found that students were able to focus better with shorter (5-7 minute) videos as opposed to longer (10-20 minute) videos, and this is an important consideration when designing flipped materials.

Another particularly interesting finding was the high prevalence of critical thinking skills when Google Docs was used. One example was a three-year study of junior secondary Integrated Humanities students in Hong Kong (Kong, 2015). The teachers used the school LMS to distribute readings and worksheets, and used Google Docs to facilitate group discussions, by providing a template to organise and share information with their group, as well as with the whole class. The students' critical thinking skills grew in overall competency across the three years, increasing their test mean score from 12.13 to 16.88 , with a particularly high growth in the second year of the study. The study revealed the importance of peer interaction, personal learning prior to lessons, and teacher support, particularly through choosing and implementing appropriate technology.

\subsection{Student disengagement and flipped learning in K-12}

Studies in this corpus were also coded on 22 different indicators of cognitive, affective and behavioural disengagement. Overall, 36 studies (34\%) resulted in behavioural disengagement, $34(32 \%)$ in affective disengagement and $30(28 \%)$ in cognitive disengagement, with 15 studies (14\%) indicating all three disengagement dimensions. The five most frequently cited 
disengagement indicators were task incompletion, frustration, unwillingness, confusion and dislike (see Table 9).

Table 9. Top five disengagement indicators across the three dimensions

\begin{tabular}{clcclcclcc}
\hline Rank & Behavioural Diseng. & $n$ & $\%$ & Affective Diseng. & $n$ & $\%$ & Cognitive Diseng. & $n$ & $\%$ \\
\hline 1 & Task incompletion & 23 & $21 \%$ & Frustration & 16 & $15 \%$ & Unwilling & 15 & $14 \%$ \\
& & & & & & Confused & & \\
2 & Unfocused/inattentive & 10 & $9 \%$ & Dislike & 14 & $13 \%$ & $\begin{array}{l}\text { Apathy } \\
\text { Opposition/Rejection }\end{array}$ & 4 & $4 \%$ \\
3 & Half-hearted & 6 & $6 \%$ & Boredom & 8 & $7 \%$ & & \\
& $\begin{array}{l}\text { Poor conduct } \\
4\end{array}$ & 5 & $5 \%$ & Worry/anxiety & 5 & $5 \%$ & - & \\
5 & Distracted & 2 & $2 \%$ & $\begin{array}{l}\text { Disinterest } \\
\text { Onprepared }\end{array}$ & & 4 & $4 \%$ & - & \\
& & & & & & \\
\end{tabular}

Note. Eng. = Engagement

As in the case of engagement, there were three studies that specified overall disengagement, but not the particular indicators, including the study by Aycicek and Yelken (2018) where, whilst disengagement remained in the post-test $(M=6.0)$, the level for the flipped group was lower than the traditional group's post-test $(\mathrm{M}=9.6)$ and lower than the flipped pre-test disengagement score $(M=9.5)$. In Bergstresser's (2017) study of Year 5-12 students with dyslexia, Science students in the traditional classroom $(\mathrm{M}=2.27)$ were more disengaged than students in the flipped classroom $(M=1.85)$, whereas this was reversed in History, with students in the flipped classroom $(\mathrm{M}=2.74)$ more disengaged than students in the traditional classroom $(\mathrm{M}=2.51)$. In a study of Year 7 English Language Arts students (Moran, 2018), which used the Motivation Strategies Learning Questionnaire (Pintrich et al., 1991), student engagement decreased after a flipped unit in three out of four subscales; intrinsic motivation (pre-test $\mathrm{M}=4.63, \mathrm{SD}=.98$; post-test $\mathrm{M}=4.39, \mathrm{SD}=1.18$ ), extrinsic motivation (pre-test $\mathrm{M}$ $=5.58, \mathrm{SD}=1.03$; post-test $5.06, \mathrm{SD}=1.18$ ) and organisational strategies (pre-test $\mathrm{M}=3.98$, $\mathrm{SD}=1.20$; post-test $\mathrm{M}=3.54, \mathrm{SD}=1.32$ ). However, when observed (following the three dimensions of engagement) and interviewed, student perceptions of flipped learning "ranged from expressing intense dislike of the method to enthusiastic support" (Moran, 2018, p. 10), with slightly more students expressing a positive opinion rather than negative, giving further weight to the need to use multiple methods of data collection when investigating student engagement.

In order to provide further insight, a co-occurrence analysis was performed between technology and the instances of overall behavioural, affective and cognitive disengagement (see Table 10). The results reveal that, whilst fewer videos were made by others, they led to increased instances of behavioural and cognitive disengagement than teacher-created videos. YouTube and Khan Academy videos also led to increased behavioural and affective engagement.

Table 10. Percentage of studies using technology and student disengagement

\begin{tabular}{|c|c|c|c|c|c|c|c|c|c|c|c|}
\hline & $\begin{array}{c}\text { Videos } \\
\text { (teacher) }\end{array}$ & $\begin{array}{r}\begin{array}{l}\text { Videos } \\
\text { (others) }\end{array} \\
\end{array}$ & $\begin{array}{c}\text { Videos } \\
(?)\end{array}$ & $\begin{array}{l}\text { You } \\
\text { Tube }\end{array}$ & Khan & LMS & $\begin{array}{l}\text { Other } \\
\text { LMS }\end{array}$ & Edmodo & GC & Moodle & Quizzes \\
\hline & $n=62$ & $n=29$ & $n=20$ & $n=17$ & $n=10$ & $n=55$ & $n=24$ & $n=12$ & $n=10$ & $n=10$ & $n=58$ \\
\hline $\begin{array}{l}\text { Behavioural } \\
\text { Diseng. }\end{array}$ & $35 \%$ & $55 \%$ & $35 \%$ & $47 \%$ & $50 \%$ & $38 \%$ & $46 \%$ & $33 \%$ & $40 \%$ & $30 \%$ & $34 \%$ \\
\hline $\begin{array}{l}\text { Affective } \\
\text { Diseng. }\end{array}$ & $32 \%$ & $38 \%$ & $35 \%$ & $35 \%$ & $50 \%$ & $36 \%$ & $38 \%$ & $33 \%$ & $50 \%$ & $30 \%$ & $33 \%$ \\
\hline $\begin{array}{l}\text { Cognitive } \\
\text { Diseng. }\end{array}$ & $27 \%$ & $45 \%$ & $25 \%$ & $24 \%$ & $30 \%$ & $33 \%$ & $42 \%$ & $17 \%$ & $30 \%$ & $40 \%$ & $28 \%$ \\
\hline
\end{tabular}

Note: Diseng. = disengagement; ? = uncertain origin; LMS numbers include those that used named LMS such as Google Classroom; Other LMS = LMS not including Edmodo, Google Classroom or Moodle; GC = Google Classroom 


\subsubsection{Behavioural disengagement and flipped learning}

Behavioural disengagement was centred on eight indicators (see Table 9 for the top five), with the most prominent disengagement indicator by far being task incompletion. This related primarily to students not watching videos (e.g., Weiss, 2018), and although teachers were realistic that the flipped approach is "not magic pixie dust" (Year 8 Maths teacher, de Araujo et al., 2017, p. 67) that will make students who never do homework, suddenly start doing homework, it was still a source of frustration for teachers, after substantial time and effort were spent creating them (Goodnough \& Murphy, 2017). Some students stated that they did not see videos as having the same level of importance as other forms of homework, such as worksheets (Parham, 2018), others muted the sound and skipped through parts of videos (Sharpe, 2016), and some students admitted that they were unfocused when watching videos, even when they were only two minutes long (Cheung, Luk, \& Jong, 2016). Interestingly, videos that were not created by the teacher, were more likely not to be viewed (see Table 11). In order to try and give students a sense of accountability, some students were required to complete tasks in detention (e.g., Speller, 2015), others were not allowed to participate in certain group activities (e.g., Shaffer, 2016), and some teachers embedded more self-assessment quizzes and games (e.g., Collins, 2015), which was found crucial to the successful implementation of flipped learning in a recent meta-analysis (van Alten et al., 2019).

Table 11. Relative frequency of behavioural disengagement indicators by technology (in three or more articles)

\begin{tabular}{|c|c|c|c|c|c|c|c|c|c|c|c|c|c|c|c|}
\hline & 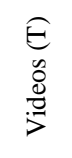 & 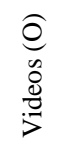 & 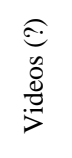 & $\sum_{\lrcorner}^{\infty}$ & 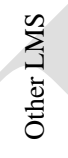 & $\stackrel{\mathscr{d}}{\mathbb{N}}$ & $\begin{array}{l}\ddot{\equiv} \\
0 \\
0 \\
0 \\
0 \\
0\end{array}$ & 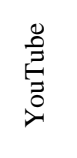 & 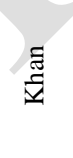 & $\begin{array}{l}\stackrel{O}{Z} \\
\stackrel{\Xi}{\Xi} \\
\text { II }\end{array}$ & 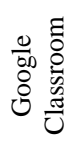 & $\begin{array}{l}\frac{0}{z} \\
\stackrel{0}{\Sigma}\end{array}$ & $\begin{array}{ll}\frac{0}{00} & \mathscr{E} \\
0 & 0 \\
0 & 0 \\
0 & 1\end{array}$ & $\begin{array}{l}\tilde{0} \\
0 \\
0 \\
0 \\
0 \\
0 \\
0\end{array}$ & $\begin{array}{l}\frac{0}{N} \\
\frac{N}{2} \\
\frac{0}{n}\end{array}$ \\
\hline Sum & 62 & 29 & 20 & 55 & 23 & 58 & 18 & 17 & 10 & 12 & 10 & 10 & 8 & 5 & 3 \\
\hline Task incompletion & $26 \%$ & $45 \%$ & $5 \%$ & $24 \%$ & $22 \%$ & $24 \%$ & $33 \%$ & $29 \%$ & $40 \%$ & $33 \%$ & $40 \%$ & $10 \%$ & $13 \%$ & $20 \%$ & $0 \%$ \\
\hline Unfocused/inattentive & $10 \%$ & $14 \%$ & $15 \%$ & $15 \%$ & $17 \%$ & $9 \%$ & $22 \%$ & $18 \%$ & $20 \%$ & $8 \%$ & $20 \%$ & $20 \%$ & $0 \%$ & $20 \%$ & $0 \%$ \\
\hline Half-hearted & $5 \%$ & $10 \%$ & $10 \%$ & $7 \%$ & $13 \%$ & $9 \%$ & $17 \%$ & $0 \%$ & $0 \%$ & $0 \%$ & $10 \%$ & $10 \%$ & $13 \%$ & $20 \%$ & $0 \%$ \\
\hline Poor conduct & $5 \%$ & $14 \%$ & $5 \%$ & $7 \%$ & $4 \%$ & $9 \%$ & $12 \%$ & $12 \%$ & $10 \%$ & $0 \%$ & $20 \%$ & $20 \%$ & $0 \%$ & $0 \%$ & $0 \%$ \\
\hline Distracted & $3 \%$ & $14 \%$ & $10 \%$ & $7 \%$ & $9 \%$ & $9 \%$ & $0 \%$ & $18 \%$ & $20 \%$ & $8 \%$ & $10 \%$ & $0 \%$ & $0 \%$ & $0 \%$ & $0 \%$ \\
\hline
\end{tabular}

Note. Videos $(\mathrm{T})=$ videos made by the teacher; Videos $(\mathrm{O})=$ videos made by others; Videos (?) = Videos of uncertain origin; LMS numbers include those that used named LMS such as Google Classroom

Within the group space, classroom observations revealed that some students struggled to stay on task during activities and were inattentive or displaying poor conduct. Examples included students not engaging in group work activities, with books closed and heads on desks (Johnson \& Renner, 2012), students preferring to work alone (Lo, 2017), students chatting and being noisy with off-task behaviour (Della Sciucca \& Fochi, 2016), and some instances of students sleeping in class (e.g., Hunley, 2016). Students also reported difficulty in self-monitoring procrastination and off-task behaviour at home, finding using mobile phones particularly difficult when receiving frequent notifications or messages (Cheung et al., 2016), or trying to stay focused when the lure of advertisements and other videos on YouTube is strong (Jo et al., 2018).

\subsubsection{Affective disengagement and flipped learning}

10 affective disengagement indicators were coded (see Table 9 for the top five), with frustration the most frequent. Students expressed frustration at not being able to log into class websites (Smith, 2016), having people who are nowhere near as far ahead asking them questions (Strohmyer, 2016), and finding it difficult when the teacher assigns videos created 
by someone else, but that do not align with class content or that are not in the method or style that the teacher would normally use to present it (Ramaglia, 2015; Wiginton, 2014), as was the case with $30 \%$ of studies using Khan Academy (see Table 12). Year 7 English students expressed their dislike and frustration at the self-paced nature of the approach, as they were overwhelmed with the amount of work they were expected to complete within a 13-day unit, which included three videos and eight stations (Moran, 2018). One student commented:

During the flip, I felt as if I didn't have enough time to finish what I needed, so I felt rushed. For this reason, I didn't really enjoy the flip and know I would have liked it more if we had more time. (p. 11)

Table 12. Relative frequency of affective disengagement indicators by technology (in three or more articles)

\begin{tabular}{|c|c|c|c|c|c|c|c|c|c|c|c|c|c|c|c|}
\hline & 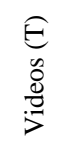 & 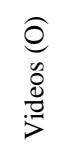 & $\begin{array}{l}\underset{\underbrace{}}{0} \\
\stackrel{0}{0} \\
\stackrel{0}{>}\end{array}$ & $\sum_{\lrcorner}^{\infty}$ & 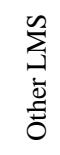 & $\begin{array}{l}\stackrel{u}{N} \\
\stackrel{N}{\Xi}\end{array}$ & 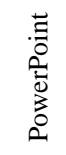 & $\underset{ٍ}{\stackrel{\Xi}{\Xi}}$ & 氶 & 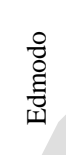 & 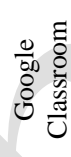 & $\begin{array}{l}\stackrel{0}{z} \\
\stackrel{0}{0}\end{array}$ & $\begin{array}{l}\frac{0}{60} \\
8 \\
80 \\
01 \\
0\end{array}$ & $\begin{array}{l}\tilde{U} \\
\dot{0} \\
\frac{0}{80} \\
\dot{0} \\
\dot{0}\end{array}$ & 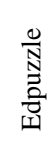 \\
\hline Sum & 62 & 29 & 20 & 55 & 23 & 58 & 18 & 17 & 10 & 12 & 10 & 10 & 8 & 5 & 3 \\
\hline Frustration & $19 \%$ & $14 \%$ & $10 \%$ & $22 \%$ & $35 \%$ & $14 \%$ & $22 \%$ & $6 \%$ & $10 \%$ & $8 \%$ & $20 \%$ & $20 \%$ & $0 \%$ & $0 \%$ & $0 \%$ \\
\hline Dislike & $16 \%$ & $10 \%$ & $10 \%$ & $18 \%$ & $22 \%$ & $17 \%$ & $17 \%$ & $6 \%$ & $30 \%$ & $17 \%$ & $20 \%$ & $10 \%$ & $13 \%$ & $0 \%$ & $0 \%$ \\
\hline Boredom & $8 \%$ & $10 \%$ & $5 \%$ & $9 \%$ & $13 \%$ & $5 \%$ & $11 \%$ & $12 \%$ & $20 \%$ & $8 \%$ & $10 \%$ & $0 \%$ & $0 \%$ & $0 \%$ & $0 \%$ \\
\hline Worry/anxiety & $3 \%$ & $7 \%$ & $15 \%$ & $4 \%$ & $0 \%$ & $5 \%$ & $6 \%$ & $6 \%$ & $0 \%$ & $0 \%$ & $10 \%$ & $20 \%$ & $0 \%$ & $0 \%$ & $0 \%$ \\
\hline Disinterest & $0 \%$ & $7 \%$ & $10 \%$ & $4 \%$ & $9 \%$ & $3 \%$ & $0 \%$ & $12 \%$ & $0 \%$ & $0 \%$ & $0 \%$ & $0 \%$ & $0 \%$ & $0 \%$ & $0 \%$ \\
\hline Overwhelmed & $5 \%$ & $0 \%$ & $5 \%$ & $4 \%$ & $9 \%$ & $2 \%$ & $11 \%$ & $0 \%$ & $0 \%$ & $0 \%$ & $0 \%$ & $0 \%$ & $0 \%$ & $0 \%$ & $0 \%$ \\
\hline Anger & $5 \%$ & $3 \%$ & $0 \%$ & $2 \%$ & $4 \%$ & $3 \%$ & $0 \%$ & $0 \%$ & $10 \%$ & $0 \%$ & $0 \%$ & $0 \%$ & $0 \%$ & $0 \%$ & $0 \%$ \\
\hline Disappointment & $3 \%$ & $7 \%$ & $0 \%$ & $4 \%$ & $9 \%$ & $3 \%$ & $6 \%$ & $0 \%$ & $10 \%$ & $0 \%$ & $0 \%$ & $0 \%$ & $0 \%$ & $0 \%$ & $0 \%$ \\
\hline
\end{tabular}

Note. Videos $(\mathrm{T})=$ videos made by the teacher; Videos $(\mathrm{O})=$ videos made by others; Videos (?) = Videos of uncertain origin; LMS numbers include those that used named LMS such as Google Classroom

Some students found taking control of their learning particularly stressful and overwhelming, being introduced to new content outside of the safety of the classroom (Leo, 2017), with some finding the requirement to use technology that was new to them (Hunley, 2016), and to ensure that work was reviewed prior to the next lesson (Wang, 2016), particularly stressful. Other students felt that their personal time was being further eaten into, with the impression that they were being given more homework (Snyder, Paska, \& Besozzi, 2014), and others being frustrated that they were not being able to ask questions of the teacher when viewing videos or content at home (Graziano \& Hall, 2017; Moran \& Young, 2014).

Students disliked flipped learning due to a number of reasons, but the quality, length and authorship of videos were particularly influential on their perceptions of the approach (DeSantis et al., 2015), with students finding watching similar videos boring (Jo et al., 2018). Some students found the videos to be impersonal (Ramaglia, 2015), with lower-achieving students in a Year 5 Maths class finding the videos more frustrating than higher achieving students (Wiley, 2015). One Year 11 Liberal Studies student in Hong Kong also found that being assigned English language videos to watch was demotivating, stating "it kills my interest to learn" (Cheung et al., 2016, p. 637).

\subsubsection{Cognitive disengagement and flipped learning}

There were only four cognitive indicators of disengagement coded in this corpus (see Table 9), with unwilling and confused equally as prevalent. Some students struggled to accept the flipped learning format (Chen, 2016), with a number of studies reporting that students were unwilling 
to complete pre-learning tasks in the individual space (e.g., Cheung et al., 2016), with one student suggesting that the approach was more appropriate for university students, not for those in high school (Avery et al., 2018). Some students found that the approach would be alright if only used for some of the time (Wang, 2016), and others suggested that flipped learning might work for other subjects, but definitely not for the one they were in (e.g., Sharpe, 2016). Surprisingly, a number of student comments expressed that they did not think that Maths - the most frequently researched subject - was best flipped (e.g., Caverly, 2017; Hunley, 2016), whereas teachers did (e.g., Hulten \& Larsson, 2018), which could be an interesting area of future focus.

A lot of student confusion came from misunderstanding video content (e.g., Weiss, 2018), and then not being able to ask questions of their teacher immediately (e.g., Graziano \& Hall, 2017), although this was more related to videos created by others (see Table 13). A student in Jong's (2017) study of Year 11 Liberal Studies, said that their small group overcame these misconceptions by discussing them with the teacher in the next available lesson, and by the teacher providing them with alternative ways to explore the issue. In a middle school study (Collins, 2015), another teacher realised that they had to explicitly model to students how to take notes and annotate them with questions, so that the students could follow them up with the teacher in the next lesson.

Table 13. Relative frequency of cognitive disengagement indicators by technology (in three or more articles)

\begin{tabular}{|c|c|c|c|c|c|c|c|c|c|c|c|c|c|c|c|}
\hline & $\begin{array}{l}E \\
0 \\
0 \\
0 \\
0 \\
\vdots\end{array}$ & 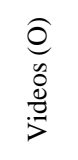 & 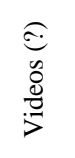 & $\sum_{3}^{\infty}$ & 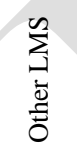 & $\begin{array}{l}\stackrel{\mathscr{N}}{N} \\
\stackrel{N}{\Xi}\end{array}$ & $\begin{array}{l}\text { בే } \\
0 \\
0 \overline{0} \\
\vdots \\
0\end{array}$ & 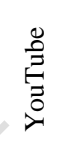 & $\underset{\Xi}{\Xi}$ & $\begin{array}{l}\frac{0}{0} \\
\stackrel{0}{Z} \\
\text { III }\end{array}$ & 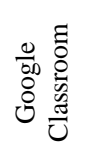 & $\begin{array}{l}\frac{0}{8} \\
\stackrel{0}{0} \\
\sum\end{array}$ & $\begin{array}{l}\frac{0}{00} \\
0 \\
0 \\
0 \\
ن \\
ن\end{array}$ & $\begin{array}{l}00 \\
0 \\
0 \\
0 \\
00 \\
0 \\
0\end{array}$ & 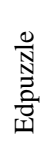 \\
\hline Sum & 62 & 29 & 20 & 55 & 24 & 58 & 18 & 17 & 10 & 12 & 10 & 10 & 8 & 5 & 3 \\
\hline Unwilling & $13 \%$ & $17 \%$ & $25 \%$ & $16 \%$ & $25 \%$ & $10 \%$ & $22 \%$ & $18 \%$ & $10 \%$ & $8 \%$ & $20 \%$ & $10 \%$ & $0 \%$ & $0 \%$ & $0 \%$ \\
\hline Confused & $15 \%$ & $17 \%$ & $20 \%$ & $20 \%$ & $25 \%$ & $16 \%$ & $11 \%$ & $12 \%$ & $20 \%$ & $8 \%$ & $10 \%$ & $30 \%$ & $13 \%$ & $0 \%$ & $0 \%$ \\
\hline Apathy & $6 \%$ & $14 \%$ & $10 \%$ & $9 \%$ & $13 \%$ & $9 \%$ & $6 \%$ & $6 \%$ & $10 \%$ & $8 \%$ & $10 \%$ & $10 \%$ & $13 \%$ & $0 \%$ & $0 \%$ \\
\hline Opposition/Rejection & $3 \%$ & $3 \%$ & $0 \%$ & $2 \%$ & $4 \%$ & $7 \%$ & $6 \%$ & $0 \%$ & $0 \%$ & $0 \%$ & $0 \%$ & $0 \%$ & $0 \%$ & $0 \%$ & $0 \%$ \\
\hline
\end{tabular}

\section{Discussion and Recommendations}

\subsection{Flipped learning and student engagement}

By using a comprehensive definition and understanding of engagement (Bond \& Bedenlier, 2019), this study found that the flipped learning approach positively affected at least one dimension of student engagement in $93 \%(n=99)$ of studies. Positive collaboration, as well as peer teaching and learning, were particularly encouraged through the approach, as were increased enjoyment, participation, and improved student-teacher relationships. However, 50\% $(n=54)$ of studies did show at least one facet of disengagement, and it is to how the approach can be more successfully implemented, alongside application of the approach in a wider variety of studies and contexts, that research must turn. The results of this review are now discussed against the bioecological model of influences on student engagement (see Figure 7) developed by the author, in an attempt to identify recommendations for schools to successfully implement the flipped learning approach, and to further our understanding of influences on student engagement. Please see Appendix I for a summary of recommendations. 


\subsubsection{Macrosystem}

Any school is impacted by wider state and federal governmental policies, including approaches to digitalisation and internet infrastructure. For example, whilst the internet was generally available at schools, issues of connectivity (e.g., Cukurbasi \& Kiyici, 2018) and of websites being blocked due to safeguarding firewalls or school policies were reported (e.g., Huereca, 2015), with a study from Hong Kong reporting that students who live in mainland China cannot access YouTube videos (Yang, 2017), which impacted - and continues to impact - on the efficacy of the approach. Schools and teachers, therefore, are encouraged to take these limitations into consideration prior to implementing the approach, and alter policies and curriculum design accordingly. Suggestions include downloading reading materials and videos from third parties, and making them available offline via the school LMS, intranet or via a USB stick from the teacher, as well as making computer labs available to families (Lewin \& Luckin, 2010). However, whilst this review found that studies using videos recorded by others were slightly more engaging overall (see Table 5) - although not in the case of Khan Academy - the co-occurrence analyses of disengagement with technology revealed that videos recorded by others were more likely to lead to task incompletion, boredom, dislike and confusion. Previous reviews (e.g., Akçayır and Akçayır, 2018) have also found that video quality is an ongoing impediment to engagement, with studies within this review finding that videos recorded by others lacked personal connection (e.g., Parham, 2018) or used different concepts than those of the classroom teacher (e.g., Manjanai \& Shahrill, 2016). Therefore, schools are advised to provide extra support and resources to teachers, to enable them to record their own videos, thereby avoiding some of the restrictions imposed at the macro level.

With previous reviews (e.g., Akçayır and Akçayır, 2018; Lo \& Hew, 2017) finding that adequately preparing units for flipped learning instruction a very time-consuming task for (first-time) teachers, it might also be pertinent for government policies to enact change, ensuring pre- and in-service teachers receive adequate professional development, as well as reductions in teaching (contact) time, to prepare their resources (Orr, Rimini, \& van Damme, 2015). This is currently being argued in South Australia, for example, by the Australian Education Union:

If the department is serious about teachers implementing individualised learning programs, such a change in pedagogy requires a new understanding from the department that 20th century staffing levels won't satisfy 21 st century pedagogy... The department asserts that in recognition of the pressure of workload, the Offer contains a reduction of face-to-face teaching time for leaders. It's a fallacy that all leaders will receive a reduction as this only applies to schools with fewer than 160 students. In proposing this solution to workload, which the AEU accepts, it should be extended to all leaders and teachers. (AEU [SA Branch], 2019, emphasis in the original) 


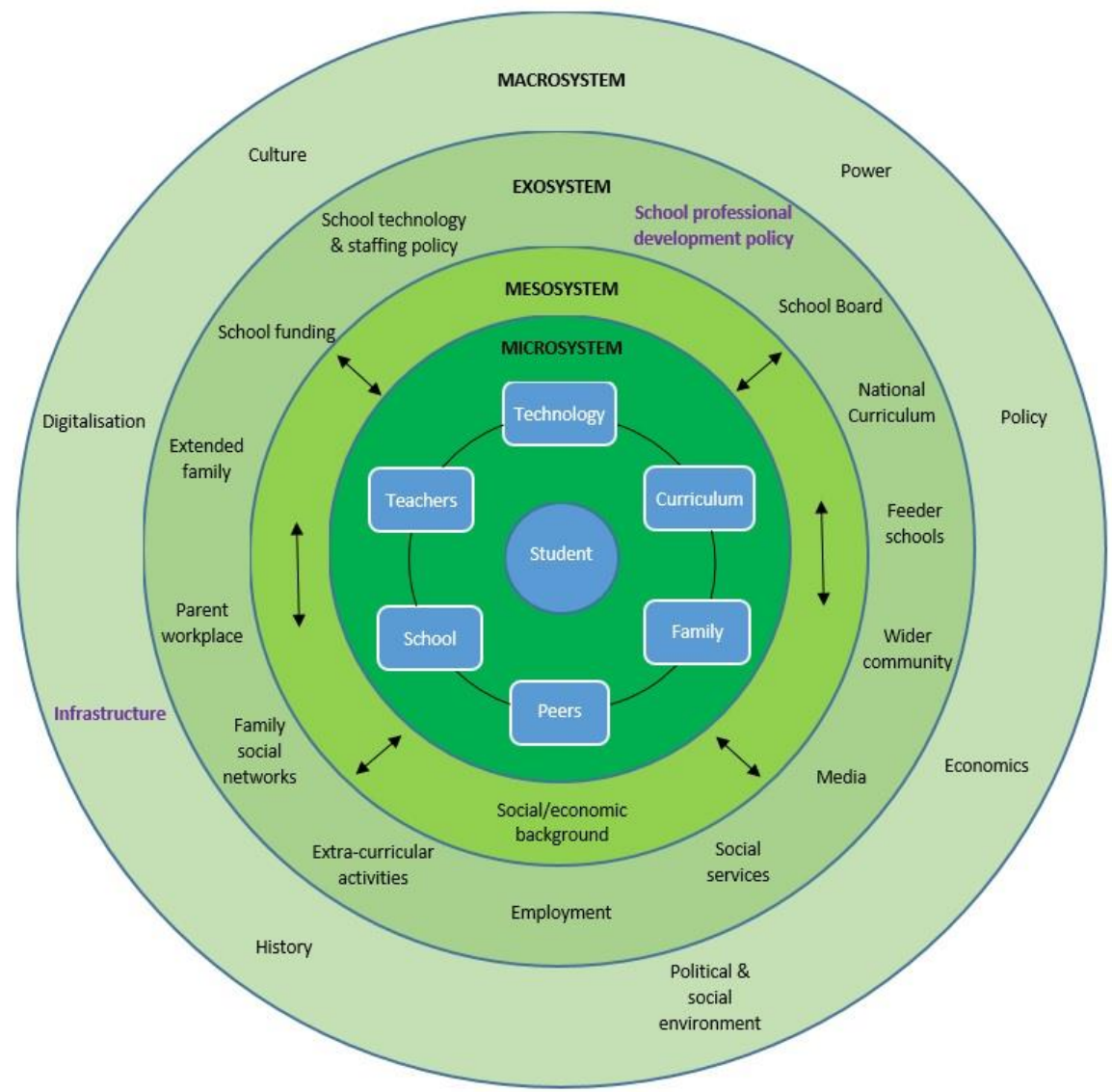

Figure 7. Revised bioecological model of influences on school student engagement, adapted from Bond (2019, p. 1305) and Bond \& Bedenlier (2019, p. 5)

\subsubsection{Exosystem}

The majority of disengagement coded in this review centred on students being unwilling or unable to engage with the approach, particularly through technology issues, or a disinterest or inability to watch videos or complete work set for the individual space. Some of this disengagement could be avoided, however, if teachers, schools, families and students are wellprepared and well-informed about the approach, which was strongly expressed by teachers (e.g., Huereca, 2015; Weidmann, 2018) and researchers (e.g., Durak, 2018; Smith, 2016) in this review. This could take the form of joint parent/teacher professional development workshops on flipped learning (see e.g., Willis, Povey, Hodges, \& Carroll, 2018), so that families and schools can work together to learn how best to implement the approach (Pushor \& Amendt, 2018). It is also strongly recommended that schools across communities work together, including feeder schools, to better prepare students and help alleviate some of the problems that students face with self-regulation once they get to middle school (Brooks \& Weaver, 2017), as well as developing stronger flipped learning communities of practice (Huereca, 2015; Pearson, 2012; Weidmann, 2018).

Increased attention should also be paid to school professional development (PD) policies, to enable teachers to undertake not only flipped learning PD, but also using technology for teaching and learning in particular, irrespective of which faculty they teach in (Bond, 2019). As found in 14.08\% of studies in the review by Akçayır and Akçayır (2018) - the most frequent challenge mentioned in that study - the flipped learning approach is time consuming for teachers, with $20 \%$ of studies in the present sample identifying that it creates more work for teachers. Teachers found creating videos and content ahead of time to be particularly taxing, 
with one high school Chemistry teacher saying "There is no shooting from the hip in a [flipped classroom]. That first year is so much work!” (Hunley, 2016, p. 80). One Mathematics teacher, for example, discussed having to practice solving equations prior to filming videos, to ensure that videos would flow and be kept short enough to maintain student attention (Snyder, 2017), and another teacher attributed the length of time it took to make videos, to trying too hard to make them perfect (Weidmann, 2018). Rather than teachers having to learn new skills and solve technical problems along the way (e.g., Shaffer, 2016), deliberate, supportive, collaborative and ongoing PD could help alleviate some of these implementation issues (Tondeur, van Keer, van Braak, \& Valcke, 2008).

Based on the results of this review, schools are also encouraged to consider widening technology policies, to include collaborative technologies such as the use of Google Docs or other collaborative brainstorming tools, to facilitate increased interaction with peers and critical thinking skills. This could potentially lead to more equitable interactions in the classroom (Collins, 2015; Grypp \& Luebeck, 2015), increased homework completion, participation and effort. However, it is recognised that some countries have strict data protection laws that do not allow the use of cloud based services, for example the recent banning in some German states of Microsoft Office 365 (Der Hessische Beauftragte für Datenschutz und Informationsfreiheit, 2019). Therefore, schools should endeavour to choose approved LMS that have similar collaborative functionality.

\subsubsection{Mesosystem}

Digital equity is an ongoing societal issue that has a huge impact on pedagogical approaches that use technology (Selwyn, 2017), with middle schools teachers $(M=4.40)$ in a US study agreeing significantly more than high school teachers $(\mathrm{M}=3.70)$ that access to technology required outside of school made using the flipped approach difficult for students (Gough et al., 2017). Limited or no access to devices such as computers and smart phones was mentioned in a number of studies (e.g. Abdul et al., 2017), and internet access is also an issue, with one Year 9 student commenting that "some people don't have Internet and can't always stay after so they get in trouble for not doing their homework" (Snyder et al., 2014, p. 314). It is therefore vital that schools conduct a needs analysis (Education Endowment Foundation, 2018) and that multiple methods to access technology are provided, at school and at home (Collins, 2015; Howell, 2013; Shaffner \& Hyland, 2017). Organising loan equipment for students to take home might be one possible means to assist families who cannot afford to purchase a device (Hohlfeld, Ritzhaupt, \& Barron, 2010). As the studies here show, digital equity remains a contemporary challenge even for developed nations.

\subsubsection{Microsystem}

\subsubsection{Teacher}

The teacher plays a crucial role in developing student engagement through a number of influences (Quin, 2017; Zepke \& Leach, 2010), such as their ICT skills and knowledge, and their use of technology both inside and outside the classroom (see Figure 8). This review found that it is important that teachers first understand flipped pedagogy, through both pre- and inservice PD, as well as through wider reading (Cheung et al., 2016; Collins, 2015; Sezer, 2017). By drawing on academic literature, Lo (2017) suggests that teachers will be able to make themselves aware of the challenges of the approach, prior to implementation. This, however, requires access to academic journals that they may no longer possess. Therefore, teachers are encouraged to enquire into Alumni access to their university library, to engage in professional networks on social media (e.g. Twitter via \#EduTwitter, \#flippedlearning, \#FLN), to undertake 
PD on flipped learning, and to join a teachers association, which can provide access to a range of resources, events and networks.

The results of this review confirmed that of others (Lo \& Hew, 2017; Lundin et al., 2018), that flipped learning can promote a more equal relationship between the teacher and students (Muir, 2016; Strohmyer, 2016), ranked the third highest benefit of flipped learning across the studies $(36 \%, n=39)$. This included improved attitudes and rapport (Chao et al., 2015; Speller, 2015), as well as building trust (Avery et al., 2018), through more one-on-one time in the group space and increased formative feedback (e.g., Bäcklund \& Hugo, 2018). One teacher in Sweden described it thus:

We have much better interaction in the classroom, where I am not some sort of omniscient person but instead we can actually work together towards common goals where I get to be a part of the work instead of someone who stands there communicating knowledge (Hulten \& Larsson, 2018, p. 438).

Aside from stronger relationships leading to teachers knowing their "students forward and backwards" (High school Science teacher, Weidmann, 2018, p. 102), the flipped approach enabled a more even power dynamic, where students recognised that teachers were also learning to use a new approach, with one Year 11 student feeling that "[teachers] can sort of relate to us more" as a result and that the videos they create make them seem "more of a person in general, not just a teacher you have at school" (Avery et al., 2018, p. 12). For educators new to the flipped learning approach, the learning curve can be steep, however teachers reported improved technology skills and self-efficacy (Goodnough \& Murphy, 2017), increased and enhanced professional reflection (Bäcklund \& Hugo, 2018), and a confidence to step out of their comfort zone to show a "willing[ness] to model to students that it's not going to be perfect for [the teacher] or for them" (Senior Biology teacher, Pearson, 2012).

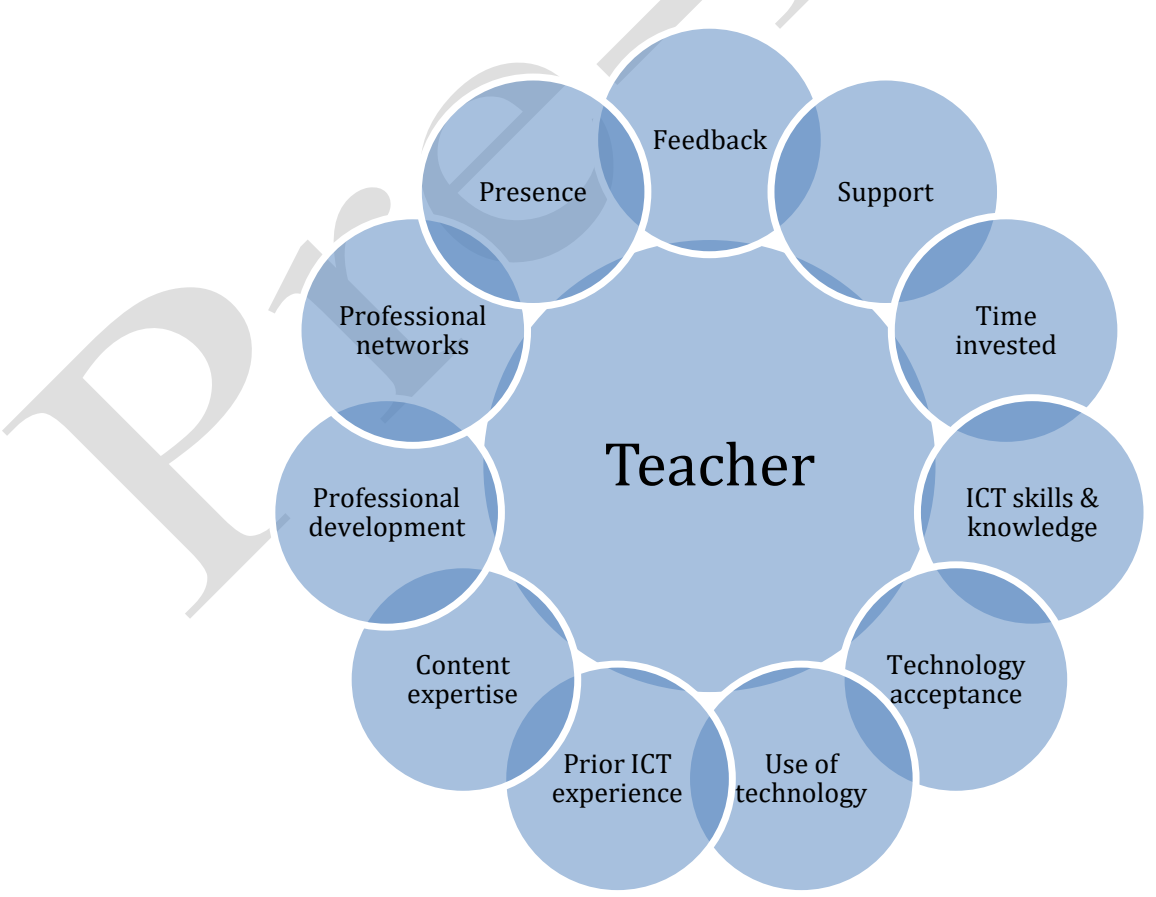

Figure 8. Teacher influences on student engagement, adapted from Bond \& Bedenlier (2019, p. 8) 
In order to facilitate continued teacher presence in student learning, and to enhance engagement, it is important for teachers to create videos themselves where possible, rather than relying on videos from other sources, as this can impede student engagement and understanding of the materials, and lead to students not watching them (Moore, Gillett, \& Steele, 2014; Muir \& Chick, 2014). Teachers should not worry if they make mistakes during videos, rather they should just keep filming, as this reflects everyday classroom situations and makes them more relatable (Huereca, 2015; Weidmann, 2018).

\subsubsection{Curriculum/Activities}

Given the vital learner-content relationship in promoting student engagement (Xiao, 2017), consideration should first be given to which units lend themselves best to flipping (Bäcklund \& Hugo, 2018; Brooks \& Weaver, 2017; Huereca, 2015). It is important not to overwhelm students with videos and worksheets, as this can lead to disengagement (Moran, 2018), and to ensure that any video content aligns with class instruction (Wiginton, 2014) (see Figure 9). Providing a recap of videos prior to beginning collaborative activities in the group space can lead to enhanced engagement (Grypp \& Luebeck, 2015; Parham, 2018; Smith, 2016), although this could also be used in conjunction with pre-class quizzes to help keep students accountable (Hodgson et al., 2017). Furthermore, given the important role of peers and collaboration in facilitating engagement, having students create their own videos for their peers could be an authentic and meaningful activity (Jong, 2017). Studies using game-based learning found that student engagement was particularly heightened (e.g., Jo, Jun, \& Lim, 2018), and Rontogiannis (2014) found that hands-on activities in the group space were particularly important for motivation and interest.

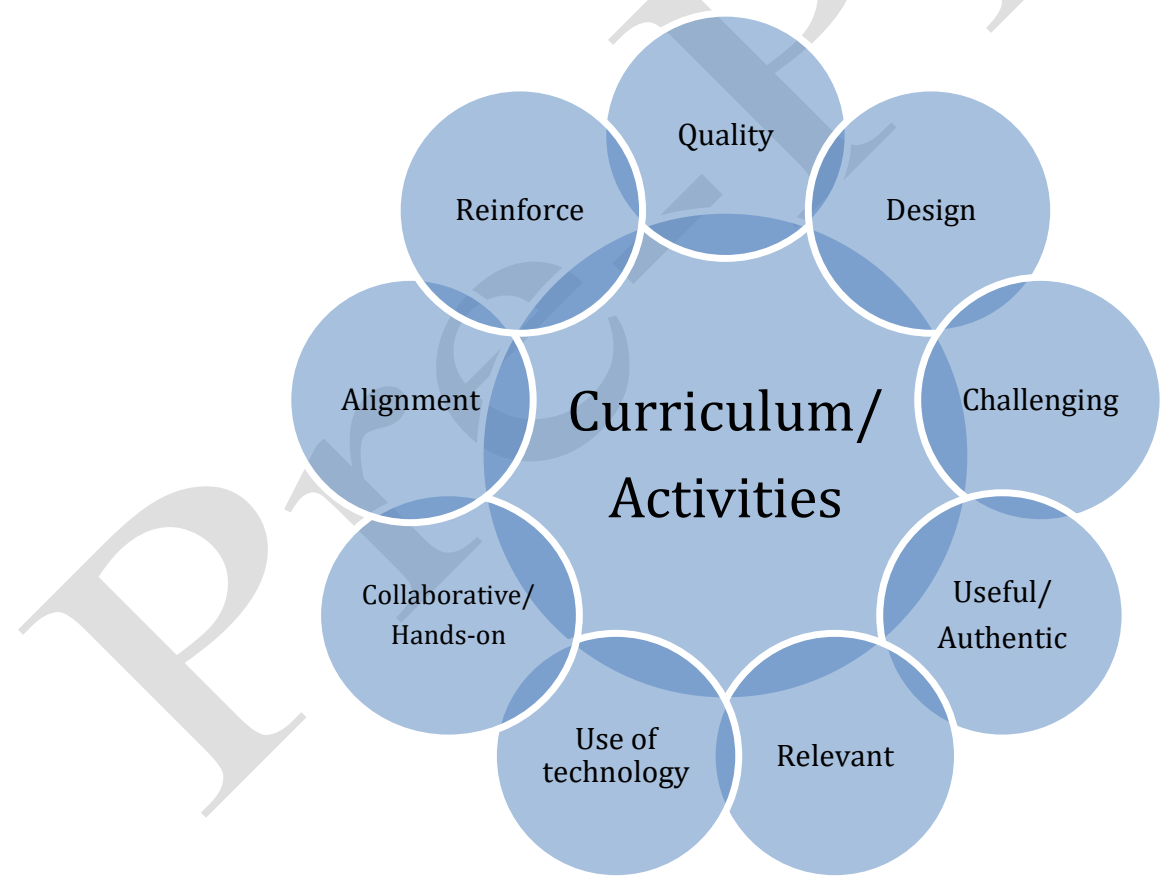

Figure 9. Curriculum/activity influences on student engagement, adapted from Bond \& Bedenlier (2019, p. 9)

\subsubsection{Technology}

Student engagement is influenced by a variety of factors when using technology (see Figure 10). The results of this review indicate that employing an LMS that offers collaborative opportunities between the teacher and students, as well as with peers, will lead to enhanced engagement. All three named LMS (Edmodo, Google Classroom and Moodle), however, outperformed other LMS systems across the three engagement dimensions, and therefore 
serious consideration should be given towards employing the use of more social tools, including Google Docs. Video quality has also been raised as a serious challenge when adopting the flipped approach (e.g., Akçayır \& Akçayır, 2018), therefore by keeping them short (less than 10 minutes), concise and clear (Slemmons et al., 2018; Weidmann, 2018; Wiley, 2015), and including questions, either as accompanying or embedded quizzes, or as guides for discussion during the next lesson, students are more likely to successfully engage with the content (Webel, Sheffel, \& Conner, 2018). Whilst it is also advisable to use videos created by others to supplement learning, such as YouTube or Khan Academy, as they are particularly linked to enjoyment, they should be used sparingly as they can lead to disengagement. If using YouTube, consider embedding videos within a website or downloading the videos to watch offline, to eliminate distractions and make them more accessible. Likewise, device appropriateness was also mentioned, in particular in regards to the size of mobile phone screens to read text (Cheung, Luk, \& Jong, 2016), therefore it is important for teachers to ensure that appropriate software is used if embedding questions or text in flipped content, and that videos and lesson content are available in multiple formats (e.g. on USB, school intranet and on external websites) and in multiple places (e.g. various devices within the classroom, school library and compatible devices at home where possible).

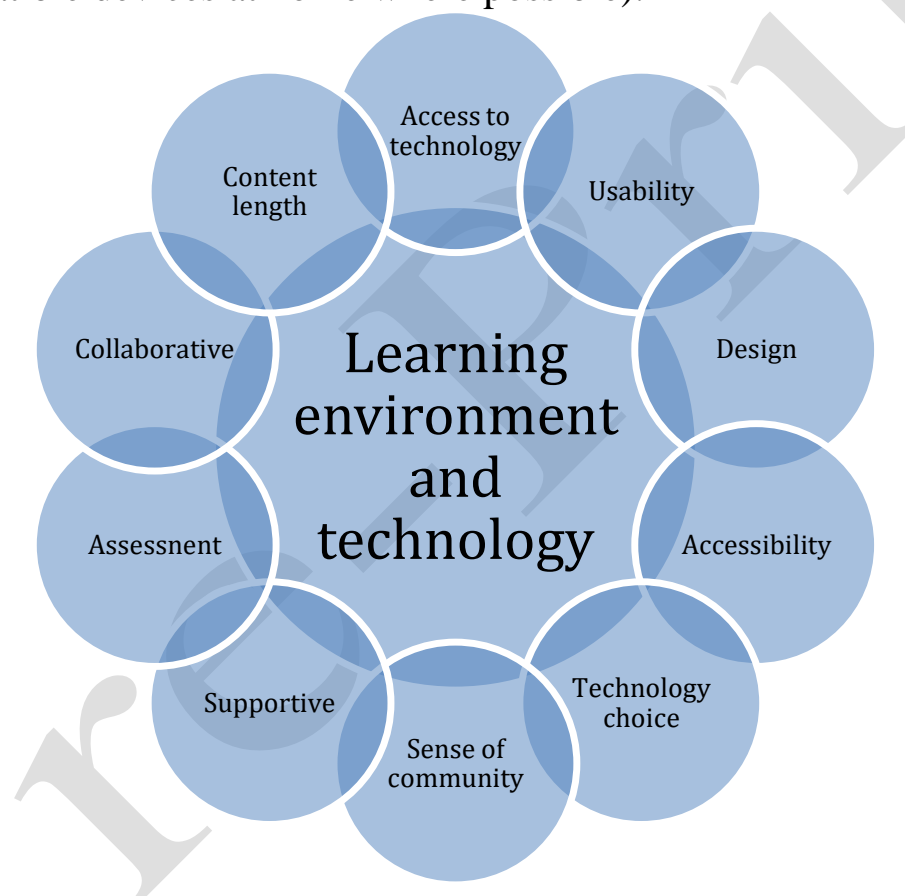

Figure 10. Learning environment and technology influences on student engagement, adapted from Bond \& Bedenlier (2019, p. 7)

\subsubsection{Students}

There are a range of internal psychosocial influences that influence student engagement (see Figure 11), including their technology acceptance and their prior ICT experience (Moos and Azevedo, 2009). Some students in this review struggled to get used to and accept flipped learning, both the aspect of learning in the individual space, such as watching videos at home (Chen, 2016), and active learning in the group space (Leo, 2017). A number of studies discussed the initial period of adjustment needed for students to become accustomed to the approach (e.g., Ripley, 2015), with one senior school Maths student describing it as "foreign to [her] because in 13 years of school [she had] always been doing it type A" (Caverly, 2017, p. 64). The approach was found particularly challenging for Year 4 Maths students (D'addato \& Miller, 2016), and they "needed more oversight and monitoring from both the teacher and the parents" (p. 40). These studies confirm the need for an initial induction period and explicit 
guidance when introducing the flipped approach for the first time on how to learn independently and as part of a group (Hunley, 2016; Schultz et al., 2014). Instructions on how to take notes whilst watching videos, for example, was found particularly beneficial (Clark, 2015; Collins, 2015).

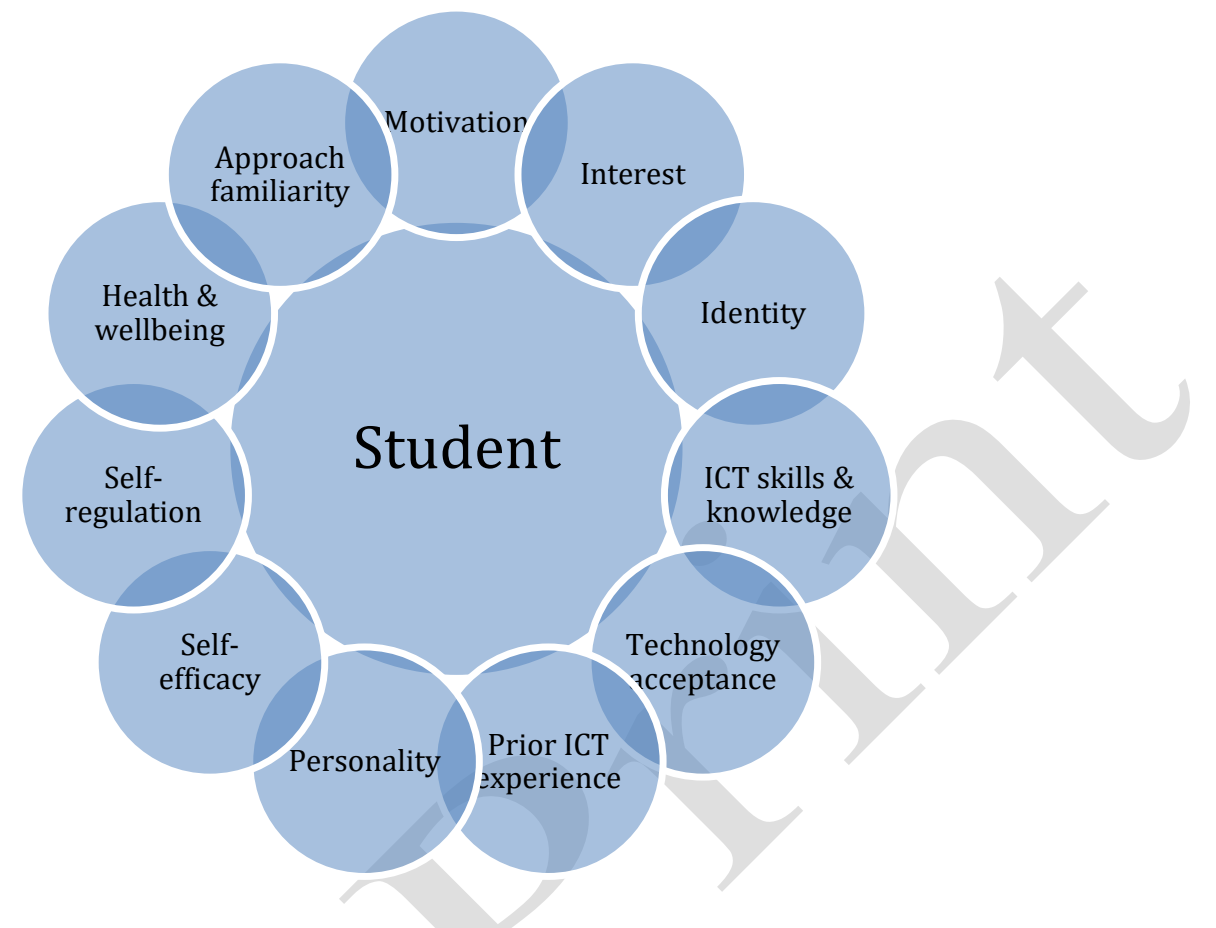

Figure 11. Internal psychosocial influences on student engagement, adapted from Bond \& Bedenlier (2019, p. 6)

\subsubsection{Family}

Family relationships affect student engagement in a number of ways (see Figure 12), including student involvement with, attitude towards and use of technology (Krause, 2014; Stevenson, 2008). Parental involvement in their children's learning tends to decrease by the time students reach middle school (Oswald, Zaidi, Cheatham, \& Brody, 2018), which can often be caused by not having access to or not understanding assigned homework (e.g., Grant, 2011). Five studies in this review reported strengthened relationships with families and heightened student engagement as a result of flipped learning (Collins, 2015; D'addato \& Miller, 2016; Oyola, 2016; Strydom, 2017; Webel et al., 2018). In a study of US middle school teachers and schools leaders (Collins, 2015), teachers reported an increase in homework completion, which they attributed to parental support at home. One teacher said:

The problem for parents is that they don't know how to do the math themselves, so they could not really help the students. But, again, if you have those parents that are willing to watch the video, building community at home, that has been an even more effective method. (Collins, 2015, p. 66).

Primary school teachers in another US study (Oyola, 2016) found that the videos helped parents better understand the curriculum and teacher methods, leading to strengthened support of the approach and a more positive attitude from parents and from students, which "has impacted how much students engage in and take from their learning opportunities" (p. 72). Therefore, it is important to not only encourage parents to watch videos with their children (Howell, 2013), but also to offer them opportunities to undertake professional development alongside teachers 
and to see flipped learning in action in classrooms (Goodnough \& Murphy, 2017; Hunley, 2016). Videos could also be used to update families on their child's progress (Huereca, 2015; Oyola, 2016).

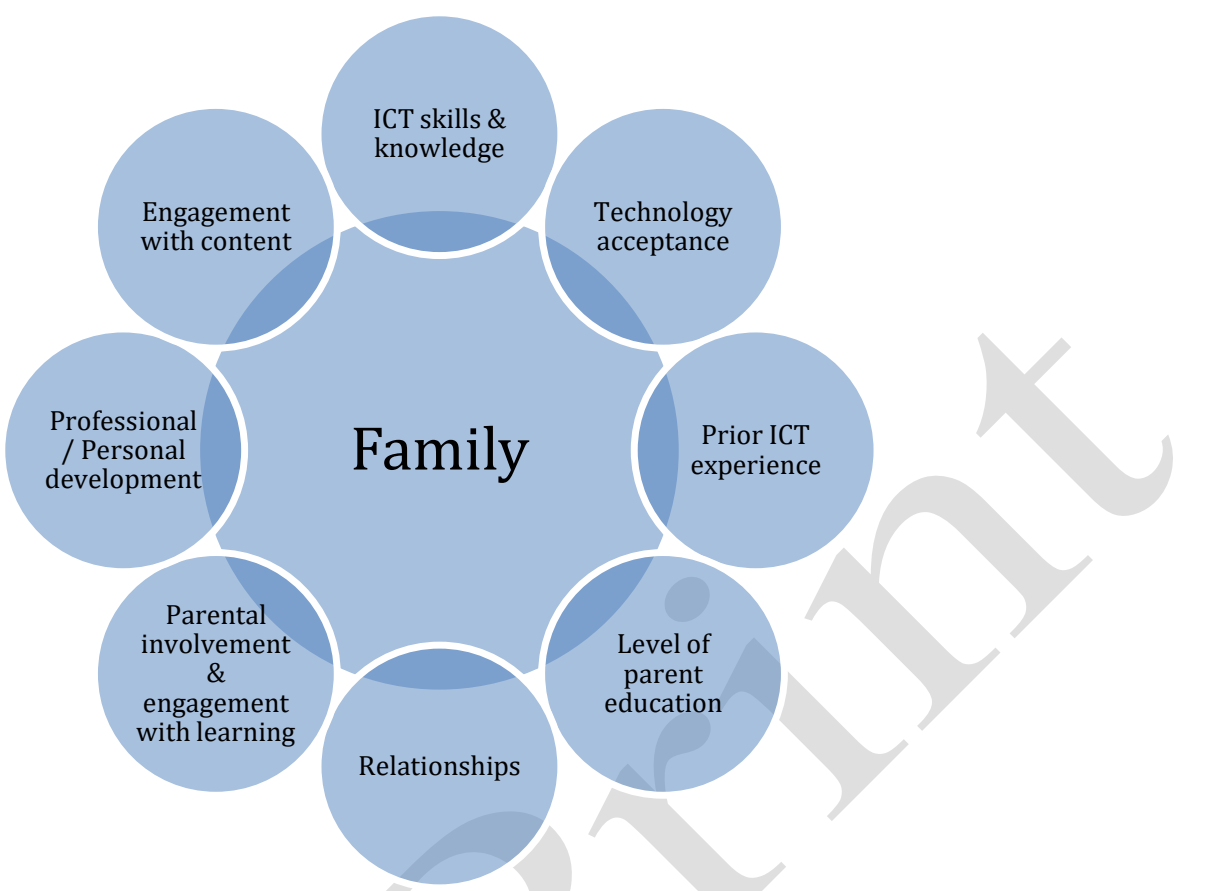

Figure 12. Family influences on student engagement, adapted from Bond \& Bedenlier (2019, p. 11)

\subsubsection{Peers}

Collaborating with peers and building effective relationships - with or without technology has been found to be extremely important for student engagement (Lo \& Hew, 2017; Nelson Laird and Kuh, 2005; Zepke and Leach, 2010), and the results of this review concur (see Figure 13). Teachers described classrooms with increased collaboration and subject-specific conversations (de Araujo et al., 2017; Moore, Gillett, \& Steele, 2014), where students moved desks to create group learning spaces (Duffy, 2016) and learned together "without fear of failure" (Researcher journal, Howell, 2013, p. 102). Teachers often described their classrooms as "more vibrant" (Ripley, 2015, p. 108) with active learning and increased noise, as students engaged in discussing concepts, helping and teaching peers (Strohmyer, 2016; Weidmann, 2018), leading to deeper learning (Shaffer, 2016). Increased opportunities to collaborate with peers was considered the most beneficial aspect of flipped learning across the studies $(41 \%, n$ $=44$ ), with Year 12 Calculus students in Grypp and Luebeck's (2015) study describing in-class collaborative activities afforded by flipped learning as allowing them to "gain clarity, ...[expand] brain power... and [help] get everyone on the same level of understanding" (p. 191), and Year 9 Maths students in Clark's (2015) study feeling that these types of group learning opportunities had allowed them to develop teamwork skills, applicable to other subjects and extra-curricular activities. In order to facilitate group discussions, interaction and engagement both within and outside of the classroom, collaborative technologies such as Google Docs and social media are encouraged (Kong, 2015; Strohmyer, 2016; Wiginton, 2014). Explicit instruction in how to learn and interact within the group space is also recommended (e.g., Hunley, 2016). 


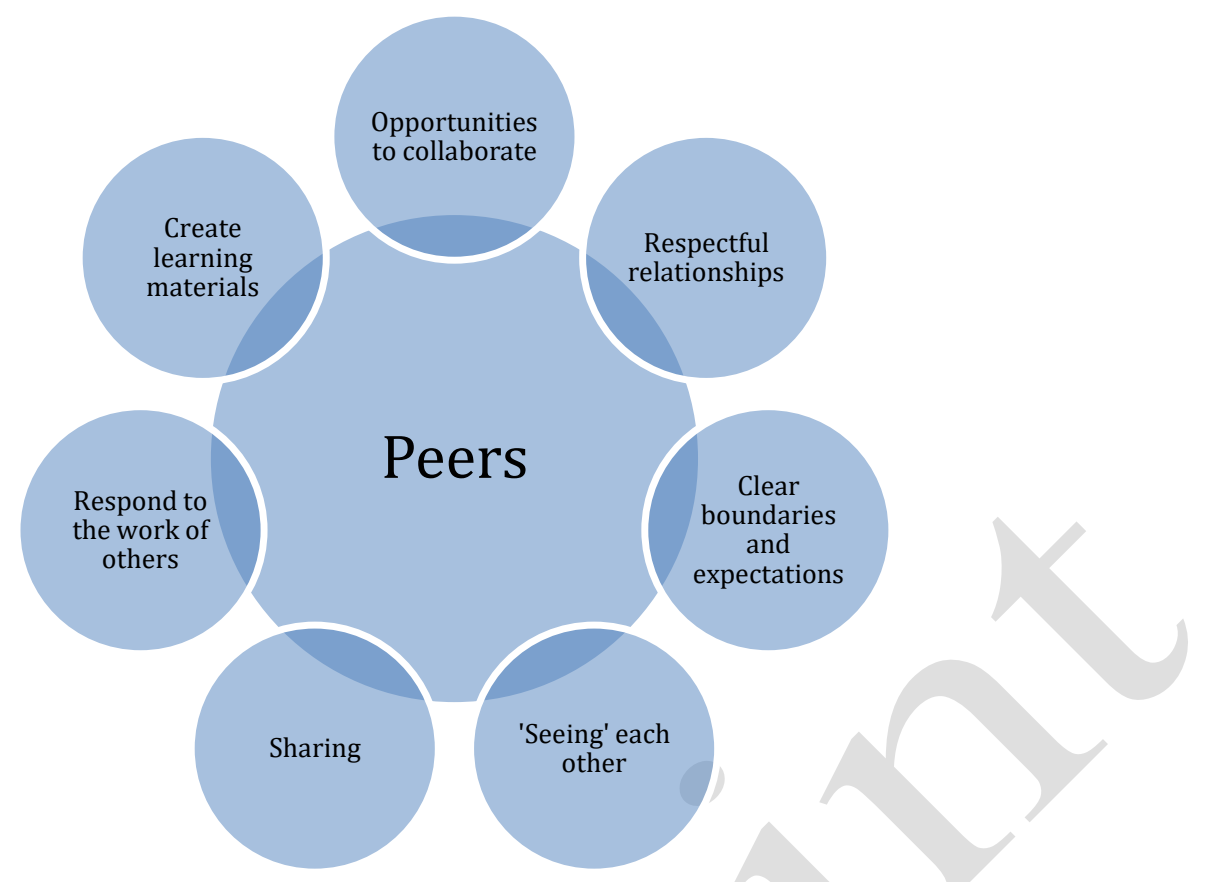

Figure 13. Peer influences on student engagement, adapted from Bond \& Bedenlier (2019, p. 11)

\subsection{Grounding K-12 flipped learning and student engagement research in theory}

Henrie et al. (2015) stated that possibly the greatest challenge of studying and measuring engagement was the breadth of understanding of the concept, with this review revealing that only $12 \%$ of the corpus included a definition. Whether studies quote directly from seminal works (e.g., Fredricks et al., 2004), or they come up with their own definition, grounded in previous research (e.g., Bond et al., 2020), it is essential that researchers conceptualise what is meant by engagement and make it explicit within their work (Appleton et al., 2008; Christenson, Reschly, \& Wylie, 2012), including which domains and indicators are being investigated (see Appendix $\mathbf{J}$ for a summary of recommendations). Future research that goes beyond easily observable indicators of student engagement is also particularly welcome, given its complex nature, including how flipped learning affects cognitive and affective engagement, but especially how it affects disengagement. Researchers are invited to use the indicators of disengagement from this review, in order to further unearth difficulties associated with the approach, and to help reach a greater understanding of how to more effectively implement flipped learning.

Also important is for flipped learning researchers to frame their work within a stronger theoretical base (Lundin et al., 2018), which is also reflective of current conversations in wider educational technology literature (e.g., Castañeda \& Selwyn, 2018; Crook, 2019; Hew et al., 2019). Whilst there were slightly more studies in this review that were guided by a theoretical framework (42\%) than those in Lundin et al.'s (2018) with 35\%, the lack of engagement with educational theories is a concern (Crook, 2019), and one that should be addressed within future flipped learning research. Researchers are therefore encouraged to use a theoretical framework, such as the one used in this review, to guide their work. They are also strongly encouraged to engage with wider literature on flipped learning and student engagement, prior to designing new studies, including consulting previous systematic reviews and meta-analyses (e.g., Lo \& Hew, 2017; van Alten et al., 2019). 


\subsection{Methodological and study design considerations in K-12 flipped learning research}

Whilst the results of this review confirm that a large amount of research has been undertaken within the US (Lo \& Hew, 2017; Lo et al., 2017; Lundin et al., 2018), it has also uncovered a variety of studies being undertaken within Asian and Middle Eastern countries. Still, this indicates that there is much scope for further studies, particularly within the UK, Oceania, Africa and South America, as "making direct comparisons across cultures is problematic and thus we need to broaden the cultural contexts within which research on educational technology is conducted" (Pérez-Sanagustín et al., 2017, A12). Further to this, whilst the majority of research has been undertaken in high schools, with Year 9 students the most frequently studied, followed by Year 11 and Year 8 students, there were some studies that did not indicate which type of school they were conducting their research in, and others that did not state a year level, or only stated one that was understandable within their own context. It is important for authors to include as much information as possible, so that readers may understand the conditions under which the research was conducted, to be able to gauge whether the results and recommendations are valuable for their own situation (Hodgson et al., 2017; Lo, 2017; Slavin, 2008).

Student perceptions of or performance within flipped learning classrooms, were by far the most researched, with only $14.2 \%$ of studies focusing solely on teacher perceptions, a mere two studies including parent perceptions, and only one study including school leaders. Given the influence that parents can have on student engagement, well-being and learning achievement (Castro et al., 2015; Doctoroff \& Arnold, 2017; Wong et al., 2018), and that there can often be a disconnect between what schools think parents know about flipped learning and engage in, and what they actually do (Bond, 2019), the lack of studies including parent and school leader perceptions is a missed opportunity to gain a more holistic understanding of how the approach affects the whole student, families and the school community. Likewise, further consideration could be given to the number of participants included within studies and the length of time that studies are undertaken, with the majority of research focused on one, two or three classes, within one or two units of work. Whilst these are also valuable, multiple-class and longitudinal studies could provide more insight into how the phenomenon affects student engagement and performance over time, and within and between classes (Akçayır \& Akçayır, 2018; Lo \& Hew, 2017).

As with other reviews (Lo \& Hew, 2017; Lundin et al., 2018), STEM subjects were the most frequently researched (60\%), with Maths by far the most studied (38.7\%). Research was limited across multiple subjects (14.2\%), and studies focusing on Humanities and foreign languages (aside from ESL) were particularly rare, although interestingly this matched some of the discussion by both students and teachers on which subjects they felt were more appropriately suited to the flipped approach (e.g., Hunley, 2016). Still, further research within non-STEM subjects would provide more insight into how to use the approach effectively within those subjects, as would the use of multiple means of data collection, including the use of qualitative methods in particular (Lo \& Hew, 2017; Lundin et al., 2018). Had some studies solely focused on achievement or quantitative data, they may have missed out, for example, that students felt more motivated and their subject and/or technology interest and self-efficacy had increased (e.g., Rontogiannis, 2014). Given the difficulty of measuring student engagement, and concerns over the rigour of students' self-reported engagement (Hodgson et al., 2017), it is therefore advised to combine a number of methods, which $81 \%$ of studies in this corpus did, including interviews, observations and surveys, but also log data, which can help shine light on aspects of engagement change over time (Henrie et al., 2015). 


\section{Limitations}

This review was limited to English-language research, published between 2012-2018, and indexed in seven databases. Whilst the search included a substantial number of databases, as opposed to similar reviews undertaken (e.g., Lundin et al., 2018), a number of other valuable research published elsewhere, or in languages other than English, might have been missed. An example of this is the Norwegian study by Østerlie (2018), which was initially missed due to the inclusion criteria. Further, this may also help explain why there is such a focus on North American and Asian research within this corpus. Therefore, future reviews should be mindful of Western-biased searches, and seek to include research from areas previously considered under-represented. For example, since this review was undertaken, the author has become aware of African Journals Online (www.ajol.info), which indexes peer-reviewed African journals from 32 African countries. Whilst the results here did reflect those in wider educational technology literature (e.g., Bond, 2018; Bond et al., 2019), this database should be considered a priority to include when searching for literature in future reviews. Another consideration could be using tools to translate non-English articles. However, given the lack of linguistic sensitivity of some translation tools (Hampshire \& Porta Salvia, 2010; Niño, 2009), great care would need to be taken in selecting the appropriate tool, and in the interpretation of results.

\section{Conclusion}

This article reviewed 107 publications on the flipped learning approach within K-12 and, in particular, focused on which indicators of student engagement and disengagement were affected, leading to a revised bioecological model of student engagement. This review identified that at least one dimension of positive engagement was found in an overwhelming majority of studies, with peer collaborative learning and teaching, enhanced enjoyment of learning, and positive peer and student-teacher relationships particularly positively affected, and linked to the use of collaborative tools such as Google Docs and social LMS (e.g. Google Classroom and Edmodo). There were, however, mixed findings in regards to student perceptions of and performance using the approach, with half of the studies reporting some form of disengagement, therefore recommendations from the corpus were provided to help educators try and mitigate this. Despite this, a particularly interesting finding in a number of studies was that, although student grades may not have improved, student attitudes, motivation, interest, self-efficacy and overall engagement were nonetheless positively affected as a result of the flipped learning approach.

This review also sought to identify whether a larger search strategy could locate literature that previous reviews identified were missing, namely research undertaken in elementary schools, non-STEM subjects, research across multiple subjects, longitudinal research, as well as research undertaken within non-US contexts. However, the findings revealed that there are still gaps in these areas, which may also indicate that the search strategy used may not have been wide enough. Consideration should therefore be given to searching in an even wider number of databases, including combing journals from underrepresented geographical or subject areas, as well as a variety of national or institutional thesis repositories. Future research might also investigate how an early and thorough education of students, parents, school leaders and the wider school community about flipped learning, might affect the implementation of the approach, including explicit instruction for students on how to collaborate and take notes effectively, as well as how to learn effectively in the group space. It could also explore the various ways that teachers try to ensure student accountability with the approach, and identify which strategies are more effective. 


\section{Acknowledgements}

The author would like to thank Dr. Svenja Bedenlier for providing comments on a previous draft, as well as the editor and anonymous peer reviewers, whose insightful and thoughtful comments helped enormously. 


\section{References}

Abdelrahman, L. A. M., Dewitt, D., Alias, N., \& Abdul Rahman, M. N. (2017). Flipped learning for ESL writing in a Sudanese school. Turkish Online Journal of Educational Technology, 2017 (November Special Issue IETC), 60-70.

Abdul, L. S., Matzin, R., Jawawi, R., Mahadi, M., Jaidin, J., Mundia, L., \& Shahrill, M. (2017). Implementing the flipped classroom model in the teaching of history. Journal of Education and Learning, 11(4), 373-380. https://doi.org/10.11591/edulearn.v11i4.6390

Abeysekera, L., \& Dawson, P. (2015). Motivation and cognitive load in the flipped classroom: definition, rationale and a call for research. Higher Education Research \& Development, 34(1), 1-14. https://doi.org/10.1080/07294360.2014.934336

Akçayır, G., \& Akçayır, M. (2018). The flipped classroom: A review of its advantages and challenges. Computers \& Education, 126, 334-345. https://doi.org/10.1016/j.compedu.2018.07.021

Al-Harbi, S. S., \& Alshumaimeri, Y. A. (2016). The flipped classroom impact in grammar class on EFL Saudi secondary school students' performances and attitudes. English Language Teaching, 9(10), 60. https://doi.org/10.5539/elt.v9n10p60

Antonenko, P. D. (2015). The instrumental value of conceptual frameworks in educational technology research. Educational Technology Research and Development, 63(1), 53-71. https://doi.org/10.1007/s11423-014-9363-4

Appleton, J. J., Christenson, S. L., \& Furlong, M. J. (2008). Student engagement with school: Critical conceptual and methodological issues of the construct. Psychology in the Schools, 45(5), 369-386. https://doi.org/10.1002/pits.20303

Astin, A. W. (1984). Student involvement: A developmental theory for higher education. Journal of College Student Development, 25(4), 297-308.

Australian Education Union (AEU) [SA Branch]. (20 August 2019). EB eNews, email communique to members.

Avery, K. F. G., Huggan, C. T., \& Preston, J. P. (2018). The flipped classroom: High school student engagement through $21^{\text {st }}$ century learning. In Education, 24(1), 4-21.

Aycicek, B., \& Yelken, T. Y. (2018). The effect of flipped classroom model on students' classroom engagement in teaching English. International Journal of Instruction, 11(2), 385-398. https://doi.org/10.12973/iji.2018.11226a

Bäcklund, J., \& Hugo, M. (2018). The paradox of the flipped classroom: One method, many intentions. Problems of Education in the $21^{\text {st }}$ Century, 76(4), 451-464. Retrieved from https://www.scopus.com/inward/record.uri?eid=2-s2.085054131304\&partnerID=40\&md5=8be4acc70bb7b4782c2fd7cbe19a5644

Barlow, T., \& Fleming, B. (2016). A science classroom that's more than a game. Teaching Science, 62(2), 31-37.

Bedenlier, S., Bond, M., Buntins, K., Zawacki-Richter, O., \& Kerres, M. (2020). Facilitating student engagement through educational technology in higher education: A systematic review in the field of arts \& humanities. Australasian Journal of Educational Technology, 36 (4), 126-150. https://doi.org/10.14742/ajet.5477

Bergmann, J., \& Sams, A. (2012). Flip your classroom: Reach every student in every class every day. Eugene, OR: International Society for Technology in Education.

Bergstresser, M. (2017). Teaching students with Dyslexia using the flipped classroom Method (Doctoral dissertation). Northcentral University, Ann Arbor. Retrieved from 
https://search.proquest.com/openview/60ae7033b7c8bc5040b793294b16f6ab/1?pqorigsite $=$ gscholar $\& \mathrm{cbl}=18750 \&$ diss $=\mathrm{y}$

Bhagat, K., Chang, C.-N., \& Chang, C.-Y. (2016). The impact of the flipped classroom on mathematics concept learning in high school. Journal of Educational Technology \& Society, 19(3), 134-142.

Bishop, J., \& Verleger, M. (2013). The flipped classroom: A survey of the research. Proceedings of the $120^{\text {th }}$ ASEE Annual Conference \& Exposition, 1-18. Retrieved from https://www.researchgate.net/publication/285935974_The flipped_classroom_A_survey of the research

Boekaerts, M. (2016). Engagement as an inherent aspect of the learning process. Learning and Instruction, 43, 76-83. https://doi.org/10.1016/j.learninstruc.2016.02.001

Bond, M. (2018). Helping doctoral students crack the publication code: An evaluation and content analysis of the Australasian Journal of Educational Technology. Australasian Journal of Educational Technology, 34 (5), 168-183. https://doi.org/10.14742/ajet.4363

Bond, M. (2019). Flipped learning and parent engagement in secondary schools: A South Australian case study. British Journal of Educational Technology, 50(3), 1294-1319. https://doi.org/10.1111/bjet.12765

Bond, M., \& Bedenlier, S. (2019). Facilitating student engagement through educational technology: Towards a conceptual framework. Journal of Interactive Media in Education, 2019(1), 1-14. https://doi.org/10.5334/jime.528

Bond, M., Buntins, K., Bedenlier, S., Zawacki-Richter, O., \& Kerres, M. (2020). Mapping research in student engagement and educational technology in higher education: A systematic evidence map. International Journal of Educational Technology in Higher Education, 17 (1), Article 2, 1-30. https://doi.org/10.1186/s41239-019-0176-8

Bond, M., Zawacki-Richter, O., \& Nichols, M. (2019). Revisiting five decades of educational technology research: A content and authorship analysis of the British Journal of Educational Technology. British Journal of Educational Technology, 50(1), 12-63. https://doi.org/10.1111/bjet.12730

Bronfenbrenner, U. (1979). The ecology of human development: Experiments by nature and design. Cambridge, Mass: Harvard University Press.

Bronfenbrenner, U. (1986). Ecology of the family as a context for human development: Research perspectives. Developmental psychology, 22(6), 723-742. https://doi.org/10.1037/0012-1649.22.6.723

Bronfenbrenner, U., \& Ceci, S. J. (1994). Nature-nurture reconceptualized in developmental perspective: A bioecological model. Psychological Review, 101(4), 568-586.

Brooks, N., \& Weaver, H. (2017). Two sides of the flip in middle grades ELA: Student and teacher perspectives. In Young C \& Moran C (Eds.), Applying the Flipped Classroom Model to English Language Arts (pp. 79-90).

Brunton, G., Stansfield, C., \& Thomas, J. (2012). Finding relevant studies. In D. Gough, S. Oliver, \& J. Thomas (Eds.), An Introduction to systematic reviews (pp. 107-134). Los Angeles, LA: Sage.

Cargile, L. A., \& Harkness, S. S. (2014). Flip or flop: Are Math teachers using Khan Academy as envisioned by Sal Khan? TechTrends, 59(6), 21-28. https://doi.org/10.1007/s11528-015-0900-8

Carlisle, C. (2018). How the flipped classroom impacts students' Math achievement (Doctoral dissertation). Ann Arbor, United States. Retrieved from 
Melissa Bond (melissa.bond@ucl.ac.uk)

https://search.proquest.com/openview/6dc2eb267827810a03841df5de107d6d/1?cbl=1875 $\underline{0 \&}$

Castañeda, L., \& Selwyn, N. (2018). More than tools? Making sense of the ongoing digitizations of higher education. International Journal of Educational Technology in Higher Education, 15(1), 211. https://doi.org/10.1186/s41239-018-0109-y

Castro, M., Expósito-Casas, E., López-Martín, E., Lizasoain, L., Navarro-Asencio, E., \& Gaviria, J. L. (2015). Parental involvement on student academic achievement: A metaanalysis. Educational Research Review, 14, 33-46.

https://doi.org/10.1016/j.edurev.2015.01.002

Caverly, G. (2017). A technology leader's role in initiating a flipped classroom in a high school math class (Doctoral dissertation). New Jersey City University, Jersey City.

Retrieved from http://gateway.proquest.com/openurl?url_ver=Z39.88-

2004\&rft_val_fmt=info:ofi/fmt:kev:mtx:dissertation\&res_dat=xri:pqm\&rft_dat=xri:pqdiss $: 10745078$

Çetinkaya, M. (2017). Designing and applying web assisted activities to be used in Flipped Classroom Model. International Journal of Evaluation and Research in Education, 6(2), 128-137.

Chaipidech, P., \& Srisawasdi, N. (2016). Mobile technology-enhanced flipped learning for scientific inquiry laboratory: A comparison of students? Perceptions and engagement. In ICCE 2016 - $24^{\text {th }}$ International Conference on Computers in Education: Think Global Act Local - Workshop Proceedings. Retrieved from https://www.scopus.com/inward/record.uri?eid=2-s2.085018939543\&partnerID=40\&md5=fb9acc31e5e6e620b9cbec1be88fef8b

Chan, P. (2016). From passive to active learning in A-level Mathematics classroom. In Proceedings of International Conference of the Learning Sciences, ICLS (Vol. 1, pp. 1302-1305). Retrieved from https://www.scopus.com/inward/record.uri?eid=2-s2.084987810000\&partnerID=40\&md5=4e84101aa41250e019cbf218a996206c

Chang, S., \& Hwang, G. (2018). Impacts of an augmented reality-based flipped learning guiding approach on students' scientific project performance and perceptions. Computers and Education, 125, 226-239. https://doi.org/10.1016/j.compedu.2018.06.007

Chao, C.-Y., Chen, Y.-T., \& Chuang, K.-Y. (2015). Exploring students' learning attitude and achievement in flipped learning supported computer aided design curriculum: A study in high school engineering education. Computer Applications in Engineering Education, 23(4), 514-526. https://doi.org/10.1002/cae.21622

Chen, F., Lui, A. M., \& Martinelli, S. M. (2017). A systematic review of the effectiveness of flipped classrooms in medical education. Medical Education, 51(6), 585-597. https://doi.org/10.1111/medu.13272

Chen, L.-L. (2016). Impacts of flipped classroom in high school health education. Journal of Educational Technology Systems, 44(4), 411-420. https://doi.org/10.1177/0047239515626371

Cheng, L., Ritzhaupt, A. D., \& Antonenko, P. (2018). Effects of the flipped classroom instructional strategy on students' learning outcomes: a meta-analysis. Educational Technology Research and Development, 44(3), 176. https://doi.org/10.1007/s11423-0189633-7

Cheston, C. C., Flickinger, T. E., \& Chisolm, M. S. (2013). Social media use in medical education: a systematic review. Academic Medicine : Journal of the Association of 
American Medical Colleges, 88(6), 893-901. https://doi.org/10.1097/ACM.0b013e31828ffc23

Cheung, K., Luk, E. T.H., \& Jong, M. S.Y. (2016). Challenges in flipping Hong Kong's classrooms. In ICCE 2016 - $24^{\text {th }}$ International Conference on Computers in Education: Think Global Act Local - Main Conference Proceedings (pp. 633-638).

Christenson, S. L., Reschly, A. L., \& Wylie, C. (Eds.). (2012). Handbook of Research on Student Engagement. Boston, MA: Springer US.

Clark, K. R. (2015). The effects of the flipped model of instruction on student engagement and performance in the secondary Mathematics classroom. Journal of Educators Online, 12(1), 91-115. Retrieved from https://search.proquest.com/docview/1697494109?accountid=12968

Claro, M., \& Ananiadou, K. (2009). $21^{\text {st }}$ Century Skills and Competences for New Millennium Learners in OECD Countries (OECD Education Working Papers No. 41). https://doi.org/10.1787/218525261154

Coates, H. (2007). A model of online and general campus-based student engagement. Assessment \& Evaluation in Higher Education, 32(2), 121-141. https://doi.org/10.1080/02602930600801878

Cohen, J., \& Smerdon, B. A. (2009). Tightening the dropout tourniquet: Easing the transition from middle to high school. Preventing School Failure: Alternative Education for Children and Youth, 53(3), 177-184. https://doi.org/10.3200/PSFL.53.3.177-184

Collins, M. A. (2015). Examining the perspectives of teachers and school building leaders on the use of the flipped classroom method in New York City public schools (Doctoral dissertation). The Sage Colleges, US. Retrieved from http://ovidsp.ovid.com/ovidweb.cgi?T=JS\&PAGE=reference $\& D=$ psyc13\&NEWS=N\&A $\mathrm{N}=2016-47708-126$

Crook, C. (2019). The "British" voice of educational technology research: $50^{\text {th }}$ birthday reflection. British Journal of Educational Technology, 50(2), 485-489. https://doi.org/10.1111/bjet.12757

Cukurbasi, B., \& Kiyici, M. (2018). High school students' views on the PBL activities supported via flipped classroom and LEGO practices. Educational Technology \& Society, 21(2), 46-61. Retrieved from https://www.j-ets.net/ETS/journals/21_2/4.pdf

D'addato, T., \& Miller, L. R. (2016). An inquiry into flipped learning in fourth grade Math instruction. Canadian Journal of Action Research, 17(2), 33-55. Retrieved from http://journals.nipissingu.ca/index.php/cjar/article/view/261

Danielson, C. (2007). Enhancing professional practice: A framework for teaching ( $2^{\text {nd }}$ ed.). Gale virtual reference library. Alexandria, Va: Association for Supervision and Curriculum Development. Retrieved from http://search.ebscohost.com/login.aspx?direct=true \&scope $=$ site $\& \mathrm{db}=$ nlebk $\& \mathrm{db}=\mathrm{nlabk} \& \mathrm{~A}$ $\mathrm{N}=189709$

De Araujo, Z., Otten, S., \& Birisci, S. (2017). Mathematics teachers' motivations for, conceptions of, and experiences with flipped instruction. Teaching and Teacher Education, 62, 60-70. https://doi.org/10.1016/j.tate.2016.11.006

Della Sciucca, S., \& Fochi, V. (2016). Flipped classroom: The point of view of the students. Journal of E-Learning and Knowledge Society, 12(3), 9-17. Retrieved from https://www.scopus.com/inward/record.uri?eid=2-s2.0-

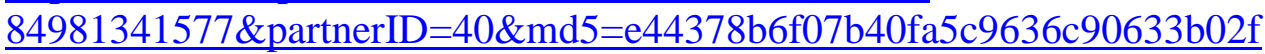


Der Hessische Beauftragte für Datenschutz und Informationsfreiheit. (2019). Stellungnahme des Hessischen Beauftragten für Datenschutz und Informationsfreiheit zum Einsatz von Microsoft Office 365 in hessischen Schulen. Retrieved from https://datenschutz.hessen.de/pressemitteilungen/stellungnahme-des-hessischenbeauftragten-f\%C3\%BCr-datenschutz-und

DeSantis, J., van Curen, R., Putsch, J., \& Metzger, J. (2015). Do students learn more from a flip? An exploration of the efficacy of flipped and traditional lessons. Journal of Interactive Learning Research, 26(1), 39-63. Retrieved from https://www.learntechlib.org/noaccess/130133/

Doctoroff, G. L., \& Arnold, D. H. (2017). Doing homework together: The relation between parenting strategies, child engagement, and achievement. Journal of Applied Developmental Psychology, 48, 103-113. https://doi.org/10.1016/j.appdev.2017.01.001

Duffy, C. M. (2016). The impact of flipped learning on student achievement in an eighth grade earth science classroom (Doctoral dissertation). Wilkes University, US. Retrieved from

http://ovidsp.ovid.com/ovidweb.cgi?T=JS\&PAGE=reference $\& D=p s y c 13 \& N E W S=N \& A$ $\mathrm{N}=2016-58396-106$

Durak, H. Y. (2018). Flipped learning readiness in teaching programming in middle schools: Modelling its relation to various variables. Journal of Computer Assisted Learning, 34(6), 939-959. https://doi.org/10.1111/jcal.12302

Eccles, J. (2016). Engagement: Where to next? Learning and Instruction, 43, 71-75. https://doi.org/10.1016/j.learninstruc.2016.02.003

Education Endowment Foundation. (2018). Working with parents to support children's learning. Retrieved from https://educationendowmentfoundation.org.uk/tools/guidancereports/working-with-parents-to-support-childrens-learning

Esperanza, P., Fabian, K., \& Toto, C. (2016). Flipped classroom model: Effects on performance, attitudes and perceptions in high school algebra. Lecture Notes in Computer Science (Including Subseries Lecture Notes in Artificial Intelligence and Lecture Notes in Bioinformatics), 9891 LNCS, 85-97. https://doi.org/10.1007/978-3-319-45153-4_7

Evans, S. C., Amaro, C. M., Herbert, R., Blossom, J. B., \& Roberts, M. C. (2018). "Are you gonna publish that?" Peer-reviewed publication outcomes of doctoral dissertations in psychology. PloS One, 13(2), e0192219. https://doi.org/10.1371/journal.pone.0192219

Filiz, S., \& Benzet, A. (2018). A content analysis of the studies on the use of flipped classrooms in foreign language education. World Journal of Education, 8(4), 72-86. https://doi.org/10.5430/wje.v8n4p72

Finn, J. (2006). The adult lives of at-risk students: The roles of attainment and engagement in high school (NCES 2006-328). Washington, DC. Retrieved from U.S. Department of Education, National Center for Education Statistics website: https://nces.ed.gov/pubs2006/2006328.pdf

Finn, J., \& Zimmer, K. (2012). Student engagement: What is it? Why does it matter? In S. L. Christenson, A. L. Reschly, \& C. Wylie (Eds.), Handbook of Research on Student Engagement (pp. 97-131). Boston, MA: Springer US. https://doi.org/10.1007/978-1-46142018-7_5

Flipped Learning Network. (2014). Definition of flipped learning. Retrieved from https://flippedlearning.org/definition-of-flipped-learning/ 
Fredricks, J. A., Blumenfeld, P. C., \& Paris, A. H. (2004). School engagement: Potential of the concept, state of the evidence. Review of Educational Research, 74(1), 59-109. https://doi.org/10.3102/00346543074001059

Fredricks, J. A., Filsecker, M., \& Lawson, M. A. (2016). Student engagement, context, and adjustment: Addressing definitional, measurement, and methodological issues. Learning and Instruction, 43, 1-4. https://doi.org/10.1016/j.learninstruc.2016.02.002

Goodnough, K., \& Murphy, E. (2017). The professional learning of grade six teachers of Mathematics implementing the flipped classroom approach. Canadian Journal of Learning and Technology, 43(1), 1-20. Retrieved from https://files.eric.ed.gov/fulltext/EJ1137648.pdf

Gough, D., Oliver, S., \& Thomas, J. (Eds.). (2012). An Introduction to systematic reviews. Los Angeles, LA: Sage.

Gough, E., DeJong, D., Grundmayer, T., \& Baron, M. (2017). K-12 teacher perceptions regarding the flipped classroom model for teaching and learning. Journal of Educational Technology Systems, 45(3), 390-423. https://doi.org/10.1177/0047239516658444

Grant, L. (2011). 'I'm a completely different person at home': using digital technologies to connect learning between home and school. Journal of Computer Assisted Learning, 27(4), 292-302. https://doi.org/10.1111/j.1365-2729.2011.00433.x

Graziano, K. J., \& Hall, J. D. (2017). Flipping Math in a secondary classroom. Journal of Computers in Mathematics and Science Teaching, 36(1), 5-16. Retrieved from http://www.learntechlib.org/p/178270

Grypp, L., \& Luebeck, J. (2015). Rotating solids and flipping instruction. Mathematics Teacher, 109(3), 186-193. Retrieved from https://www.nctm.org/Publications/Mathematics-Teacher/2015/Vol109/Issue3/RotatingSolids-and-Flipping-Instruction/

Gusenbauer, M., \& Haddaway, N. R. (2019). Which academic search systems are suitable for systematic reviews or meta-analyses? Evaluating retrieval qualities of Google Scholar, PubMed and 26 other resources. Research Synthesis Methods. Advance online publication. https://doi.org/10.1002/jrsm.1378

Haglind, T. (2016). Access and use of digital resources for learning in a digitized upper secondary school. International Journal for Digital Society, 7(3), 1177-1184. https://doi.org/10.20533/ijds.2040.2570.2016.0144

Hampshire, S., \& Porta Salvia, C. (2010). Translation and the internet: Evaluating the quality of free online machine translators. Quaderns: revista de traducció, 17, 197-209. Retrieved from https://www.raco.cat/index.php/QuadernsTraduccio/article/view/194256

Henrie, C. R., Halverson, L. R., \& Graham, C. R. (2015). Measuring student engagement in technology-mediated learning: A review. Computers \& Education, 90, 36-53. https://doi.org/10.1016/j.compedu.2015.09.005

Hew, K. F., Lan, M., Tang, Y., Jia, C., \& Lo, C. K. (2019). Where is the "theory" within the field of educational technology research? British Journal of Educational Technology, 50(3), 956-971. https://doi.org/10.1111/bjet.12770

Hodgson, T. R., Cunningham, A., McGee, D., Kinne, L., \& Murphy, T. (2017). Assessing behavioral engagement in flipped and non-flipped Mathematics classrooms: Teacher abilities and other potential factors. International Journal of Education in Mathematics Science and Technology, 5(4), 248-261. https://doi.org/10.18404/ijemst.296538

Hoffmann, T. C., Glasziou, P. P., Boutron, I., Milne, R., Perera, R., Moher, D., . . Michie, S. (2014). Better reporting of interventions: Template for intervention description and 
replication (TIDieR) checklist and guide. BMJ (Clinical Research Ed.), 348, g1687. https://doi.org/10.1136/bmj.g1687

Hoffmann, T. C., Walker, M. F., Langhorne, P., Eames, S., Thomas, E., \& Glasziou, P. (2015). What's in a name? The challenge of describing interventions in systematic reviews: Analysis of a random sample of reviews of non-pharmacological stroke interventions. BMJ Open, 5(11), e009051. https://doi.org/10.1136/bmjopen-2015-009051

Hohlfeld, T. N., Ritzhaupt, A. D., \& Barron, A. E. (2010). Connecting schools, community, and family with ICT: Four-year trends related to school level and SES of public schools in Florida. Computers \& Education, 55, 391-405. https://doi.org/10.1016/j.compedu.2010.02.004

Howell, D. (2013). Effects of an inverted instructional delivery model on achievement of ninth-grade physical Science honors students. Gardner-Webb University, Boiling Springs. Retrieved from https://eric.ed.gov/?id=ED563593

Huang, Y.-N., \& Hong, Z.-R. (2016). The effects of a flipped English classroom intervention on students' information and communication technology and English reading comprehension. Educational Technology Research and Development, 64(2), 175-193. https://doi.org/10.1007/s11423-015-9412-7

Huereca, K. (2015). High school mathematics teachers' connective knowledge of the challenges and possibilities in implementing the Flipped Learning Model: An embedded mixed-methods study (Doctoral dissertation). University of Texas at El Paso, US.

Hulten, M., \& Larsson, B. (2018). The flipped classroom: Primary and secondary teachers' views on an educational movement in schools in Sweden today. Scandinavian Journal of Educational Research, 62(3), 433-443. https://doi.org/10.1080/00313831.2016.1258662

Hunley, R. (2016). Teacher and student perceptions on high school Science flipped classrooms: Educational breakthrough or media hype? East Tennessee State University, Johnson City (Doctoral dissertation). Retrieved from https://dc.etsu.edu/cgi/viewcontent.cgi?article=4383\&context=etd

Hunsu, N. J., Adesope, O., \& Bayly, D. J. (2016). A meta-analysis of the effects of audience response systems (clicker-based technologies) on cognition and affect. Computers \& Education, 94, 102-119. https://doi.org/10.1016/j.compedu.2015.11.013

Hwang, G-J, \& Lai, C-L. (2017). Facilitating and bridging out-of-class and in-class Learning: an interactive e-book-based flipped learning approach for Math courses. Educational Technology \& Society, 20(1), 184-197. Retrieved from https://www.jstor.org/stable/pdf/jeductechsoci.20.1.184.pdf

Jimerson, S. R., Campos, E., \& Greif, J. L. (2003). Toward an understanding of definitions and measures of school engagement and related terms. The California School Psychologist, 8(1), 7-27. https://doi.org/10.1007/BF03340893

Jo, J., Jun, H., \& Lim, H. (2018). A comparative study on gamification of the flipped classroom in engineering education to enhance the effects of learning. Computer Applications in Engineering Education, 26(5), 1626-1640. https://doi.org/10.1002/cae.21992

Johnson, L. W., \& Renner, J. D. (2012). Effect of the flipped classroom model on secondary computer applications course: student and teacher perceptions, questions and student achievement (Doctoral dissertation). University of Louisville, St. Louisville. Retrieved from https://theflippedclassroom.files.wordpress.com/2012/04/johnson-renner-2012.pdf

Jong, M. S.-Y. (2017). Empowering students in the process of social inquiry learning through flipping the classroom. Educational Technology and Society, 20(1), 306-322. Retrieved 
from https://www.scopus.com/inward/record.uri?eid=2-s2.085010473732\&partnerID=40\&md5=3593b5758cd2495aadced21d29f0cfa8

Kahu, E. R. (2013). Framing student engagement in higher education. Studies in Higher Education, 38(5), 758-773. https://doi.org/10.1080/03075079.2011.598505

Kaliisa, R., \& Picard, M. (2017). A systematic review on mobile learning in higher education: The African perspective. Turkish Online Journal of Educational Technology, 16(1). Retrieved from https://files.eric.ed.gov/fulltext/EJ1124918.pdf

Karabulut-Ilgu, A., Jaramillo Cherrez, N., \& Jahren, C. T. (2018). A systematic review of research on the flipped learning method in engineering education. British Journal of Educational Technology, 49(3), 398-411. https://doi.org/10.1111/bjet.12548

Katsa, M., Sergis, S., \& Sampson, D. G. (2016). Investigating the potential of the flipped classroom model in K-12 Mathematics teaching and learning. In $13^{\text {th }}$ International Conference on Cognition and Exploratory Learning in Digital Age (pp. 210-218).

Kay, R. H., \& LeSage, A. (2009). Examining the benefits and challenges of using audience response systems: A review of the literature. Computers \& Education, 53(3), 819-827. https://doi.org/10.1016/j.compedu.2009.05.001

Keller, J. M. (2010). Tools to support motivational design. In J. M. Keller (Ed.), Motivational Design for Learning and Performance (pp. 267-295). Boston, MA: Springer US. https://doi.org/10.1007/978-1-4419-1250-3_11

Kirvan, R., Rakes, C. R., \& Zamora, R. (2015). Flipping an algebra classroom: Analyzing, modeling, and solving systems of linear equations. Computers in the Schools, 32(3/4), 201-223. Retrieved from http://search.ebscohost.com/login.aspx?direct=true \&db=trh\&AN=111003745\&site=ehostlive

Kong, S. C. (2014). Developing information literacy and critical thinking skills through domain knowledge learning in digital classrooms: An experience of practicing flipped classroom strategy. Computers \& Education, 78, 160-173. https://doi.org/10.1016/j.compedu.2014.05.009

Kong, S. C. (2015). An experience of a three-year study on the development of critical thinking skills in flipped secondary classrooms with pedagogical and technological support. Computers \& Education, 89, 16-31. https://doi.org/10.1016/j.compedu.2015.08.017

Kostaris, C., Sergis, S., Sampson, D. G., Giannakos, M. N., \& Pelliccione, L. (2017). Investigating the potential of the flipped classroom model in K-12 ICT teaching and learning: An action research study. Educational Technology \& Society, 20(1), 261-273. Retrieved from http://www.ifets.info/journals/20_1/23.pdf

Krause, L. (2014). Examining stakeholder perceptions of accessibility and utilization of computer and internet technology in the Selinsgrove Area School District (Doctoral dissertation). Drexel University, Philadelphia. Retrieved from https://eric.ed.gov/?id=ED569546.

Kuh, G. D., Cruce, T. M., Shoup, R., Kinzie, J., \& Gonyea, R. M. (2008). Unmasking the effects of student engagement on first-year college grades and persistence. The Journal of Higher Education, 79(5), 540-563. Retrieved from http://www.jstor.org.ezproxy.umuc.edu/stable/25144692

Lai, C., \& Hwang, G. (2016). A self-regulated flipped classroom approach to improving students' learning performance in a mathematics course. Computers \& Education, 100, 126-140. https://doi.org/10.1016/j.compedu.2016.05.006 
Lazarus, S. (2018). Instructional choices, student participation, and the construction of knowledge in a Social Studies learning environment (Doctoral dissertation). Arizona State University, Tempe. Retrieved from https://repository.asu.edu/attachments/211390/content/Lazarus_asu_0010E_18455.pdf

Lee, M. (2018). Flipped classroom as an alternative future class model? Implications of South Korea's social experiment. Educational Technology Research and Development, 66(3), 837-857. https://doi.org/10.1007/s11423-018-9587-9

Leo, C. (2017). Flipped classroom pedagogical model and middle-level Mathematics achievment: An action research study (Doctoral dissertation). University of South Carolina, Columbia. Retrieved from https://scholarcommons.sc.edu/etd/4304

Leo, J., \& Puzio, K. (2016). Flipped instruction in a high school Science classroom. Journal of Science Education and Technology, 25(5), 775-781. https://doi.org/10.1007/s10956$\underline{016-9634-4}$

Lewin, C., \& Luckin, R. (2010). Technology to support parental engagement in elementary education: Lessons learned from the UK. Computers \& Education, 54, 749-758. https://doi.org/10.1016/j.compedu.2009.08.010

Liberati, A., Altman, D. G., Tetzlaff, J., Mulrow, C., Gøtzsche, P. C., Ioannidis, J. P. A., . . . Moher, D. (2009). The PRISMA statement for reporting systematic reviews and metaanalyses of studies that evaluate healthcare interventions: Explanation and elaboration. BMJ (Clinical Research Ed.), 339, b2700. https://doi.org/10.1136/bmj.b2700

Lo, C., Lie, C. W., \& Hew, K. (2018). Applying "First Principles of Instruction" as a design theory of the flipped classroom. Computers \& Education, 118, 150-165.

https://doi.org/10.1016/j.compedu.2017.12.003

Lo, C. (2017). Examining the Flipped Classroom through Action Research. Mathematics Teacher, 110(8), 624-627. Retrieved from http://www.jstor.org/stable/10.5951/mathteacher.110.8.0624

Lo, C., \& Hew, K. (2017). A critical review of flipped classroom challenges in K-12 education: possible solutions and recommendations for future research. Research and Practice in Technology Enhanced Learning, 12(1). https://doi.org/10.1186/s41039-016$\underline{0044-2}$

Lo, C. K., Hew, K. F., \& Chen, G. (2017). Toward a set of design principles for mathematics flipped classrooms: A synthesis of research in mathematics education. Educational Research Review, 22, 50-73. https://doi.org/10.1016/j.edurev.2017.08.002

Lundin, M., Bergviken Rensfeldt, A., Hillman, T., Lantz-Andersson, A., \& Peterson, L. (2018). Higher education dominance and siloed knowledge: a systematic review of flipped classroom research. International Journal of Educational Technology in Higher Education, 15(1), 1. https://doi.org/10.1186/s41239-018-0101-6

Ma, J., Han, X., Yang, J., \& Cheng, J. (2015). Examining the necessary condition for engagement in an online learning environment based on learning analytics approach: The role of the instructor. The Internet and Higher Education, 24, 26-34. https://doi.org/10.1016/j.iheduc.2014.09.005

Manjanai, S. N.N.P., \& Shahrill, M. (2016). Introducing the flipped classroom strategy in the learning of Year Nine factorization. International Journal of Interdisciplinary Educational Studies, 11(4), 35-55. https://doi.org/10.18848/2327-011X/CGP

Martin, A. (2013). From will to skill: The psychology of motivation, instruction, and learning in today's classroom. InPsych, 35(6). Retrieved from https://www.psychology.org.au/inpsych/2013/december/martin/ 
Martin, A. G., Arrambide, M., \& Holt, C. (2016). The impact of flipped instruction on middle school mathematics achievement. Journal of Education and Human Development, 5(4), 98-108. https://doi.org/10.15640/jehd.v5n4a10

Maynard, B. R., Vaughn, M. G., Sarteschi, C. M., \& Berglund, A. H. (2014). Social Work Dissertation Research: Contributing to Scholarly Discourse or the File Drawer? British Journal of Social Work, 44(4), 1045-1062. https://doi.org/10.1093/bjsw/bcs172

Mohanty, A. (2016). Exploring the efficacy \& suitability of Flipped Classroom instruction at school level in India: A pilot study. Creative Education, 7(5), 768-776. https://doi.org/10.4236/ce.2016.75079

Moher, D., Liberati, A., Tetzlaff, J., \& Altman, D. G. (2009). Preferred reporting items for systematic reviews and meta-analyses: the PRISMA statement. BMJ (Clinical Research Ed.), 339, b2535. https://doi.org/10.1136/bmj.b2535

Moore, A. J., Gillett, M. R., \& Steele, M. D. (2014). Fostering Student Engagement with the Flip. Mathematics Teacher, 107(6), 420-425.

Moos, D.C., \& Azevedo, R. (2009). Learning with computer-based learning environments: A literature review of computer self-efficacy. Review of Educational Research, 79(2), 576600.

Moran, C. (2018). “Just don’t bore us to death": Seventh graders' perceptions of flipping a technology-mediated English Language Arts unit. Middle Grades Review, 4(1), 1-19. Retrieved from https://scholarworks.uvm.edu/mgreview/vol4/iss 1/5

Moran, C., \& Young, C. A. (2014). Active learning in the flipped English Language Arts classroom. In L. Tomei, J. Keengwe, G. Onchwari, \& J. N. Oigara (Eds.), Advances in Educational Technologies and Instructional Design. Promoting Active Learning through the Flipped Classroom Model (Vol. 94, pp. 163-184). IGI Global. https://doi.org/10.4018/978-1-4666-4987-3.ch009

Muir, T. (2016). No More "What are we doing in Maths today?" Affordances of the flipped classroom approach. In B. White, M. Chinnappan, \& S. Trenholm (Eds.), Opening up mathematics education research (Proceedings of the $39^{\text {th }}$ annual conference of the Mathematics Education Research Group of Australasia) (pp. 487-494). Retrieved from https://search.proquest.com/docview/1895970683?accountid=12968

Muir, T., \& Chick, H. (2014). Flipping the classroom: A case study of a Mathematics methods class. In J. Anderson, M. Cavanagh, \& A. Prescott (Eds.), Curriculum in focus: Research guided practice (Proceedings of the $37^{\text {th }}$ annual conference of the Mathematics Education Research Group of Australasia) (pp. 485-492). Retrieved from https://search.proquest.com/docview/1895971122?accountid=12968

Muir, T., \& Geiger, V. (2016). The affordances of using a flipped classroom approach in the teaching of mathematics: a case study of a grade 10 mathematics class. Mathematics Education Research Journal, 28(1), 149-171. https://doi.org/10.1007/s13394-015-0165-8

Mullis, I.V.S., Martin, M.O., Foy, P., \& Arora, A. (2012). TIMSS 2011 international results in mathematics. Chesnut Hill, MA: TIMSS \& PIRLS International Study Center, Boston College.

Nelson Laird, T.F. and Kuh, G.D. (2005). Student experiences with information technology and their relationship to other aspects of student engagement. Research in Higher Education, 46(2), 211-233. https://doi.org/10.1007/s11162-004-1600-y

Nikou, S. A., \& Economides, A. A. (2018). Mobile-based assessment: A literature review of publications in major referred journals from 2009 to 2018. Computers \& Education, 125, 101-119. https://doi.org/10.1016/j.compedu.2018.06.006 
Niño, A. (2009). Machine translation in foreign language learning: language learners' and tutors' perceptions of its advantages and disadvantages. ReCALL, 21(2), 241-258. https://doi.org/10.1017/S0958344009000172

Njie-Carr, V. P. S., Ludeman, E., Lee, Mei, Dordunoo, D., Trocky, N. M., \& Jenkins, L. S. (2017). An integrative review of flipped classroom teaching models in nursing education. Journal of Professional Nursing : Official Journal of the American Association of Colleges of Nursing, 33(2), 133-144. https://doi.org/10.1016/j.profnurs.2016.07.001

OECD. (2018). Teaching for the Future: Effective classroom practices to transform education. Paris: OECD Publishing. https://doi.org/10.1787/9789264293243-en

O'Flaherty, J., Phillips, C., Karanicolas, S., Snelling, C., \& Winning, T. (2015). Corrigendum to "The use of flipped classrooms in higher education: A scoping review" [The Internet and Higher Education 25 (2015) 85-95]. The Internet and Higher Education, 27, 90. https://doi.org/10.1016/j.iheduc.2015.05.001

Olakanmi, E. E. (2017). The Effects of a Flipped Classroom Model of Instruction on Students' Performance and Attitudes towards Chemistry. Journal of Science Education and Technology, 26(1), 127-137. https://doi.org/10.1007/s10956-016-9657-x

Orr, D., Rimini, M., \& van Damme, D. (2015). Open Educational Resources: A catalyst for innovation (Educational Research and Innovation). Paris. https://doi.org/10.1787/9789264247543-en

Østerlie, O. (2018). Adolescents' perceived cost of attending physical education. Journal for Research in Arts and Sports Education, 02(03), 1-17. https://doi.org/10.23865/jased.v4.1197

Oswald, D. P., Zaidi, H. B., Cheatham, D. S., \& Brody, K. G. D. (2018). Correlates of parent involvement in students' learning: Examination of a national data set. Journal of Child and Family Studies, 27(1), 316-323. https://doi.org/10.1007/s10826-017-0876-4

Oyola, M. (2016). Content Planning and Delivery in a Flipped Classroom: A Qualitative Examination (Doctoral dissertation). Missouri Baptist University, US. Retrieved from https://search.proquest.com/docview/1769825896

Parham, T. (2018). An Action Research Study of Female Calculus Students' Perceptions of the Flipped Classroom Model (Doctoral dissertation). University of South Carolina, Columbia. Retrieved from https://scholarcommons.sc.edu/etd/4700

Payne, L. (2017). Student engagement: three models for its investigation. Journal of Further and Higher Education, 3(2), 1-17. https://doi.org/10.1080/0309877X.2017.1391186

Pearson, G. (2012). Biology teacher's flipped classroom: “A simple thing, but it's so powerful”. Education Canada, 52(5). Retrieved from https://eric.ed.gov/?id=EJ992828

Pekrun, R., \& Linnenbrink-Garcia, L. (2012). Academic emotions and student engagement. In S. L. Christenson, A. L. Reschly, \& C. Wylie (Eds.), Handbook of Research on Student Engagement (pp. 259-282). Boston, MA: Springer US. Retrieved from http://link.springer.com/10.1007/978-1-4614-2018-7_12

Pengfei, G., \& Mingxuan, C. (2016). Flipped classroom: Teaching experience from practice. In Proceedings - 2015 International Conference of Educational Innovation Through Technology, EITT 2015. https://doi.org/10.1109/EITT.2015.40

Pérez-Sanagustín, M., Nussbaum, M., Hilliger, I., Alario-Hoyos, C., Heller, R. S., Twining, P., \& Tsai, Chin-Chung. (2017). Research on ICT in K-12 schools - A review of experimental and survey-based studies in Computers \& Education 2011 to 2015. Computers \& Education, 104, A1-A15. https://doi.org/10.1016/j.compedu.2016.09.006 
Perrella, J. (2016). Flipped learning and second language communicative performance in middle school learners: Dissertation Abstracts International. Hofstra University, US. Retrieved from http://ovidsp.ovid.com/ovidweb.cgi?T=JS\&PAGE=reference $\& D=p s y c 13 \& N E W S=N \& A$ $\mathrm{N}=2017-19719-118$

Petticrew, M, \& Roberts, H. (2006). Systematic Reviews in the Social Sciences. Malden: Blackwell Publishing.

Pintrich, P., Smith, D., Garcia, T., \& McKeachie, W. (1991). A Manual for the Use of the Motivated Strategies for Learning Questionnaire (MSLQ). Ann Arbor, MI.

Pushor, D., \& Amendt, T. (2018). Leading an examination of beliefs and assumptions about parents. School Leadership \& Management, 38(2), 202-221. https://doi.org/10.1080/13632434.2018.1439466

Quin, D. (2017). Longitudinal and contextual associations between teacher-student relationships and student engagement. Review of Educational Research, 87(2), 345-387. https://doi.org/10.3102/0034654316669434

Ramaglia, H. (2015). The flipped mathematics classroom: A mixed methods study examining achievement, active learning, and perception (Doctoral Dissertation). Kansas State University, Manhattan. Retrieved from http://hdl.handle.net/2097/20540

Reeve, J. (2013). How students create motivationally supportive learning environments for themselves: The concept of agentic engagement. Journal of Educational Psychology, 105(3), 579-595. https://doi.org/10.1037/a0032690

Reschly, A. L., \& Christenson, S. L. (2012). Jingle, jangle, and conceptual haziness: Evolution and future directions of the engagement construct. In S. L. Christenson, A. L. Reschly, \& C. Wylie (Eds.), Handbook of Research on Student Engagement (pp. 3-19). Boston, MA: Springer US. Retrieved from http://link.springer.com/10.1007/978-1-46142018-7_1

Ripley, D. G. (2015). An examination of flipped instructional method on sixth graders' mathematics learning: Utilizing propensity score matching (Doctoral dissertation). University of Nevada, Reno. Retrieved from https://scholarworks.unr.edu/bitstream/handle/11714/2518/Ripley_unr_0139D_11805.pdf? sequence $=1 \&$ is Allowed $=\mathrm{y}$

Ronnebaum, D. (2018). A Comparison of Course Practices and Student Outcomes in Traditional Lecture Versus Modified Flipped Algebra I Classrooms (Doctoral dissertation). University of Kansas, Ann Arbor. Retrieved from https://kuscholarworks.ku.edu/bitstream/handle/1808/27566/Ronnebaum_ku_0099D_1597 5_DATA_1.pdf? sequence $=1 \&$ isAllowed $=\mathrm{y}$

Rontogiannis, L. (2014). Flipping and flexing in science: The flipped classroom and the i2Flex model. In Proceedings - IEEE $14^{\text {th }}$ International Conference on Advanced Learning Technologies, ICALT 2014 (pp. 740-741). https://doi.org/10.1109/ICALT.2014.216

Saunders, J. M. (2014). The flipped classroom: Its effect on student academic achievement and critical thinking skills in high school mathematics (Doctoral dissertation). Liberty University, US. Retrieved from http://ovidsp.ovid.com/ovidweb.cgi?T=JS\&PAGE=reference \&D=psyc12\&NEWS=N\&A $\mathrm{N}=2015-99170-388$

Schindler, L. A., Burkholder, G. J., Morad, O. A., \& Marsh, C. (2017). Computer-based technology and student engagement: a critical review of the literature. International 
Journal of Educational Technology in Higher Education, 14(1), 1-28. https://doi.org/10.1186/s41239-017-0063-0

Schultz, D., Duffield, S., Rasmussen, S. C., \& Wageman, J. (2014). Effects of the flipped classroom model on student performance for advanced placement high school chemistry students. Journal of Chemical Education, 91(9), 1334-1339. Retrieved from http://search.ebscohost.com/login. aspx?direct=true \&db=trh\&AN=98546850\& site=ehostlive

Schwab, J. T. (1973). The Practical 3: Translation into curriculum. The School Review, 81(4), 501-522. Retrieved from https://www.jstor.org/stable/1084423

Seery, M. K. (2015). Flipped learning in higher education chemistry: emerging trends and potential directions. Chemistry Education Research and Practice, 16(4), 758-768. https://doi.org/10.1039/c5rp00136f

Selwyn, N. (2017). Education and technology: Key issues and debates ( $2^{\text {nd }}$ edition). London, New York: Bloomsbury Academic an imprint of Bloomsbury Publishing Plc.

Sezer, B. (2017). The effectiveness of a technology-enhanced flipped Science classroom. Journal of Educational Computing Research, 55(4), 471-494. https://doi.org/10.1177/0735633116671325

Shaffer, S. (2016). One high school English teacher: On his way to a flipped classroom. Journal of Adolescent \& Adult Literacy, 59(5), 563-573. Retrieved from https://www2.ewu.edu/Documents/CALE/Education/one\%20high\%20school\%20teacher \%20on\%20his\%20way\%20to\%20flipped\%20classroom.pdf

Shaffner, S., \& Hyland, A. (2017). Flipping our urban charter ELA classes: Structuring high school ELA curriculum with Google Classroom. In C. Young, \& C. Moran (Eds.), Applying the Flipped Classroom Model to English Language Arts Education (pp. 142159). Hershey, PA: IGI Global. https://doi.org/10.4018/978-1-5225-2242-3.ch008

Sharpe, E. H. (2016). An investigation of the flipped classroom in algebra two with trigonometry classes (Doctoral dissertation). Regent University, US. Retrieved from http://ovidsp.ovid.com/ovidweb.cgi?T=JS\&PAGE=reference \&D=psyc13\&NEWS=N\&A $\mathrm{N}=2017-16342-292$

Skinner, E., Kindermann, Thomas A., \& Furrer, Carrie J. (2009). A motivational perspective on engagement and disaffection. Educational and Psychological Measurement, 69(3), 493-525. https://doi.org/10.1177/0013164408323233

Slavin, R. E. (2008). Perspectives on evidence-based research in education-What works? Issues in synthesizing educational program evaluations. Educational Researcher, 37(1), 514. https://doi.org/10.3102/0013189X08314117

Slemmons, K., Anyanwu, K., Hames, J., Grabski, D., Mlsna, J., Simkins, E., \& Cook, P. (2018). The impact of video length on learning in a middle-level flipped Science setting: Implications for diversity inclusion. Journal of Science Education and Technology, 1-11. https://doi.org/10.1007/s10956-018-9736-2

Smith, D. (2016). Lessons learned from designing flipped lessons for fourth grade students: implications for school librarians. Library Hi Tech News, 33(8), 19-23. https://doi.org/10.1108/LHTN-08-2016-0037

Snyder, N. (2017). Teachers' perceived advantages and disadvantages of using flipped classrooms in ELA and non-ELA classrooms. In Young C \& Moran C (Eds.), Applying the Flipped Classroom Model to English Language Arts (pp. 59-78). 
Snyder, C., Besozzi, D., Paska, L., \& Oppenlander, J. (2016). Is flipping worth the fuss: A mixed methods case study of screencasting in the Social Studies classroom. American Secondary Education, 45(1), 28-45.

Snyder, C., Paska, L. M., \& Besozzi, D. (2014). Cast from the past: Using dcreencasting in the Social Studies vlassroom. Social Studies, 105(6), 310-314. Retrieved from http://search.ebscohost.com/login.aspx?direct=true \&db=trh\&AN=98354538\&site=ehostlive

Song, Y., \& Kapur, M. (2017). How to flip the classroom - "Productive failure or traditional flipped classroom” Pedagogical Design? Educational Technology \& Society, 20(1), 292-

305. Retrieved from https://www.jstor.org/stable/pdf/jeductechsoci.20.1.292.pdf

Speller, S. (2015). Mathematics Teacher's Experience with Flipped Learning: A

Phenomenographic Approach (Doctoral dissertation). The University of Toledo, Toledo. Retrieved from https://etd.ohiolink.edu/!etd.send_file?accession=toledo1449855833\&disposition=inline

Stevenson, O. (2008). Ubiquitous presence, partial use: The everyday interaction of children and their families with ICT. Technology, Pedagogy and Education, 17(2), 115-130. https://doi.org/10.1080/14759390802098615

Strohmyer, D. A. (2016). Student perceptions of flipped learning in a high school math classroom (Doctoral dissertation). Walden University, US. Retrieved from http://ovidsp.ovid.com/ovidweb.cgi?T=JS\&PAGE=reference\&D=psyc13\&NEWS=N\&A $\mathrm{N}=2016-47714-276$

Strydom, A. (2017). The effect of virtual learning environments in an ESL classroom: A case study. International Journal of Innovation, Creativity and Change, 3(2), 49-59. Retrieved from https://www.scopus.com/inward/record.uri?eid=2-s2.085032175653\&partnerID=40\&md5=105295ac8167db0c503ae33edb2a6907

Tao, S. Y., Huang, Y., \& Tsai, M. (2017). Applying the flipped classroom with game-based learning in elementary school students' English learning. In Proceedings - $5^{\text {th }}$ International Conference on Educational Innovation through Technology, EITT 2016. https://doi.org/10.1109/EITT.2016.19

Tarazi, N. (2016). The influence of the inverted classroom on student achievement and motivation for learning in secondary mathematics in the United Arab Emirates: A quasiexperimental study (Doctoral dissertation). Northcentral University, Precott Valley. Retrieved from http://ovidsp.ovid.com/ovidweb.cgi?T=JS\&PAGE=reference $\& D=p s y c 13 \& N E W S=N \& A$ $\mathrm{N}=2016-58396-266$

Teo, W.C., \& Sathappan, R. (2018). The effectiveness of using Flipped Classroom Approach to teach adjectives to Malaysian Year 4 Chinese ESL learner. The English Teacher, 47(2), 53-63. Retrieved from http://journals.melta.org.my/index.php/tet/article/view/622/382

Tondeur, J., van Keer, H., van Braak, J., \& Valcke, M. (2008). ICT integration in the classroom: Challenging the potential of a school policy. Computers \& Education, 51(1), 212-223. https://doi.org/10.1016/j.compedu.2007.05.003

Tsai, C., Shen, P. D., \& Lu, Y. J. (2015). The effects of problem-based learning with flipped classroom on elementary students' computing skills: A case study of the production of ebooks. International Journal of Information and Communication Technology Education, 2, 836-845. https://doi.org/10.4018/978-1-4666-8246-7.ch046 
Turan, Z., \& Goktas, Y. (2016). The flipped classroom: Instructional efficency and impact of achievement and cognitive load levels. Journal of E-Learning and Knowledge Society, 12(4), 51-62. Retrieved from https://www.learntechlib.org/p/173672/

Tütüncü, N., \& Aksu, M. (2018). A systematic review of flipped classroom studies in Turkish education. International Journal of Social Sciences and Education Research, 4(2), 207229. Retrieved from http://dergipark.gov.tr/ijsser/issue/36972/405647

Unruh, T., Peters, M. L., \& Willis, J. (2016). Flip this classroom: A comparative study. Computers in the Schools, 33(1), 38-58. https://doi.org/10.1080/07380569.2016.1139988

Van Alten, D. C.D., Phielix, C., Janssen, J., \& Kester, L. (2019). Effects of flipping the classroom on learning outcomes and satisfaction: A meta-analysis. Educational Research Review, 28, 100281. https://doi.org/10.1016/j.edurev.2019.05.003

Voronina, M., Moroz, O., Sudarikov, A., Rakhimzhanova, M., \& Muratbakeev, E. (2017). Systematic review and results of the experiment of a flipped learning model for the courses of Descriptive Geometry, Engineering and Computer Graphics, Computer Geometry. Eurasia Journal of Mathematics Science and Technology Education, 13(8), 4831-4845. https://doi.org/10.12973/eurasia.2017.00967a

Wang, Y. (2016). Could a mobile-assisted learning system support flipped classrooms for classical Chinese learning? Journal of Computer Assisted Learning, 32(5), 391-415. https://doi.org/10.1111/jcal.12141

Wang, Z., Bergin, C., \& Bergin, D. (2014). Measuring engagement in fourth to twelfth grade classrooms: the Classroom Engagement Inventory. School Psychology Quarterly: the Official Journal of the Division of School Psychology, American Psychological Association, 29(4), 517-535. https://doi.org/10.1037/spq0000050

Ward, M., Knowlton, M. C., \& Laney, C. W. (2018). The flip side of traditional nursing education: A literature review. Nurse Education in Practice, 29, 163-171. https://doi.org/10.1016/j.nepr.2018.01.003

Webel, C., Sheffel, C., \& Conner, K. (2018). Flipping instruction in a fifth grade class: A case of an elementary mathematics specialist. Teaching and Teacher Education, 71, 271282. https://doi.org/10.1016/j.tate.2018.01.007

Weidmann, J. (2018). A Phenomenological Exploration of Secondary Teachers' Perceptions of the Flipped Classroom Model (Doctoral dissertation). Liberty University, Lynchburg.

Weiss, D. (2018). The Effects of a Flipped Classroom Model in an Affluent Suburban Honors Biology Classroom (Doctoral dissertation). Trevecca Nazarene University, Ann Arbor.

Wiginton, B. L. (2014). Flipped instruction: An investigation into the effect of learning environment on student self-efficacy, learning style, and academic achievement in an Algebra I classroom (Doctoral dissertation). The University of Alabama, Tuscaloola. Retrieved from http://ovidsp.ovid.com/ovidweb.cgi?T=JS\&PAGE=reference $\& D=$ psyc11\&NEWS $=N \& A$ $\underline{\mathrm{N}=2014-99230-220}$

Wiley, B. M. (2015). The Impact of the flipped classroom model of instruction on fifth grade mathematics students (Doctoral dissertation). University of Minnesota, Minneapolis. Retrieved from http://ovidsp.ovid.com/ovidweb.cgi?T=JS\&PAGE=reference $\& D=p s y c 13 \& N E W S=N \& A$ $\mathrm{N}=2016-31152-279$

Willis, L.-D., Povey, J., Hodges, J., \& Carroll, A. (2018). PES - Parent engagement in schools. Brisbane, QLD. Retrieved from The University of Queensland, Institute for Social Science Research website: https://issr.uq.edu.au/parent-engagement-schools 
Willms, J. D., Friesen, S., \& Milton, P. (2009). What did you do in school today?:

Transforming classrooms through social, academic and intellectual engagement. Toronto, Ontario: Canadian Education Association.

Winter, J. W. (2017). Performance and Motivation in a Middle School Flipped Learning Course. TechTrends, 62(2), 176-183. https://doi.org/10.1007/s11528-017-0228-7

Winter, J. W. (2018). Analysis of knowledge construction during group space activities in a flipped learning course. Journal of Computer Assisted Learning, 34(6), 720-730. https://doi.org/10.1111/jcal.12279

Wong, R., Ho, F. K. W., Wong, W., Tung, K. T. S., Chow, C. B., Rao, N., . . Ip, P. (2018). Parental involvement in primary school education: Its relationship with children's academic performance and psychosocial competence through engaging children with school. Journal of Child and Family Studies, 27(5), 1544-1555. https://doi.org/10.1007/s10826-017-1011-2

Xiao, J. (2017). Learner-content interaction in distance education: The weakest link in interaction research. Distance Education, 38(1), 123-135.

Yang, C. (2017). An investigation of the use of the "Flipped Classroom" pedagogy in secondary English language classrooms. Journal of Information Technology EducationInnovations in Practice, 16, 1-20. Retrieved from http://www.informingscience.org/Publications/3635

Ye, S. H., Hsiao, T. Y., \& Sun, C. T. (2018). Using commercial video games in flipped classrooms to support physical concept construction. Journal of Computer Assisted Learning, 34(5), 602-614. https://doi.org/10.1111/jcal.12267

Zawacki-Richter, O., \& Latchem, C. (2018). Exploring four decades of research in Computers \& Education. Computers \& Education, 122, 136-152. https://doi.org/10.1016/j.compedu.2018.04.001

Zepke, N., \& Leach, L. (2010). Improving student engagement: Ten proposals for action. Active Learning in Higher Education, 11(3), 167-177.

https://doi.org/10.1177/1469787410379680 